\title{
An original settlement during the Tardiglacial in Brittany: the rock shelter of Kerbizien in Huelgoat
}

Un visage original du Tardiglaciaire en Bretagne : les occupations aziliennes dans l'abri-sous-roche de Kerbizien à Huelgoat

Grégor Marchand, Jean-Laurent Monnier, François Pustoc'h and Laurent Quesnel

\section{OpenEdition}

\section{Journals}

Electronic version

URL: http://journals.openedition.org/paleo/3012

DOI: $10.4000 /$ paleo.3012

ISSN: 2101-0420

\section{Publisher}

SAMRA

Printed version

Date of publication: 28 December 2014

Number of pages: 125-168

ISSN: $1145-3370$

\section{Electronic reference}

Grégor Marchand, Jean-Laurent Monnier, François Pustoc'h and Laurent Quesnel, « An original settlement during the Tardiglacial in Brittany: the rock shelter of Kerbizien in Huelgoat », PALEO [Online], 25 | 2014, Online since 02 June 2016, connection on 07 July 2020. URL : http:// journals.openedition.org/paleo/3012 ; DOI : https://doi.org/10.4000/paleo.3012

This text was automatically generated on 7 July 2020 .

\section{(c) (†) $\odot$}

PALEO est mis à disposition selon les termes de la licence Creative Commons Attribution - Pas d'Utilisation Commerciale - Pas de Modification 4.0 International. 


\title{
An original settlement during the Tardiglacial in Brittany: the rock shelter of Kerbizien in Huelgoat
}

\author{
Un visage original du Tardiglaciaire en Bretagne : les occupations aziliennes \\ dans l'abri-sous-roche de Kerbizien à Huelgoat \\ Grégor Marchand, Jean-Laurent Monnier, François Pustoc'h and Laurent \\ Quesnel
}

It is particularly gratifying to us to thank Mrs Anne-Marie Mazurier (owner of the land) and Jean-Michel Moullec for his valuable guidance on his work. We are grateful to the Regional Archaeological Service (Jean-Yves Tinevez and Emile Bernard) and the Conseil General of Finistère (Michel Le Goffic and Sophie Casadebaig) for financing the project. Our gratitude also goes to the excavators: Nicolas Audier, Bernard Bodinier, Alex de Brie, Jean-Marc Cardeilhac, Aude Chevallier, Laurence Dorvault, Annette Flageul, Sophie Hérisson, Nadège Jouanet Aldous, André Lenormand, George Leprince, Carole Vigouroux and Jean-Pierre Toularastel.

\section{1 - The Late Glacial in north-western France}

1 A cave excavated in the nineteenth century (Roc'h Toul), some Azilian points scattered over the territory: the final Palaeolithic of north-western France has long been largely immersed in shadow (Monnier 1980). In turn, little developed sedimentary contexts, therefore less favourable than elsewhere for preserving the late Pleistocene levels, a misunderstanding of the associated lithic industries by the actors of archaeology or again the lack of suitable research program could be invoked. In 1999, the rescue excavation of the late Azilian site of les Chaloignes (Mozé-sur-Louet, Maine-et-Loire), south of Angers, showed the potential of some small valleys, although the acid soils of the Armorican Massif did not allow the preservation of bones and thus limited the palaeo-economic interpretations (Marchand et al. 2008, 2009, 2011a). Around fifty sites inventoried later in North-western France contributed to further embed this cultural group in space (Marchand et al. 2004), but without any radiometric dating to organize 
the finds (fig. 1). By typological analogy, these Azilian sites could be placed without much risk in the Alleröd, in particular in a late phase with monopoints. Technological analysis of the later lithic industries, established on the reference sites of le Camp d'Auvours in the Sarthe region and la Fosse in the Mayenne region, showed other economics dynamics probably contemporary of the Younger Dryas or the early Preboreal (Naudinot 2010, 2013). The transition to the Mesolithic therefore includes new steps in a process well-integrated with those of the neighbouring regions, but the initial stages, marked in the rest of France by a bipoints phase, are yet to be documented.

2 Despite these chronological and sedimentary limitations, this gradual emergence of knowledge of the late Pleistocene in the Armorican Massif accompanies an awareness of two geographical constraints that had a decisive influence on the prehistoric economic organization and behaviours. Firstly, the lack of flint in the geological formations has always resulted in regional prehistory in the use of flint pebbles found on the beach or in importation from afar, with a growing cost as one moved west of the peninsula. At all times, this requirement influenced the size of the resulting products and the productivity of the blocks, while the adoption of certain rocks from the substrate prompted adaptations of the debitage methods. The choices of the people involved had direct impacts on the technical systems and reveal much about their values, the organization of work or again their social networks (Marchand 2012, 2014). What then were the options adopted in the Late Glacial? And what do they tell us about the societies of the time?

Secondly, the oceanic dimension weighs on these regions, although it is difficult to take into account in the Upper Palaeolithic because of the flooding of the coastal strip during the marine transgression. With sea levels more than sixty meters lower than presently during the Alleröd, the Late Glacial shorelines were removed by 10 to $15 \mathrm{~km}$ from the current coastline. The Armorican peninsula was already emerging, closing at the south a huge estuary that drained the Rhine, the Seine, the Somme and the Thames Rivers, and that is known as the "Palaeo-Channel". We are entitled to assume that its shores were coveted spaces because ethnography rightly showed all the prodigality of some maritime predations economies (Yesner 1980; Kelly 2007). For Brittany, the preferential acquisition of coastal pebbles to manufacture stone tools shows in negative this presently submerged area as a permanent reminder of its importance. Another consequence of the implantation on a peninsula, the interactions with neighbouring communities were necessarily more reduced than in a continental zone, thus causing possible stylistic specificities.

4 The excavation of an early Azilian level at the bottom of the rock-shelter of Kerbizien, by the town of Huelgoat (Finistère), west of the Breton peninsula, is part of this renewal of knowledge. It brings a very original functional signature that echoes in the palaeoeconomic considerations being developed in the region.

\section{2 - The Kerbizien rock shelter}

\section{1 - A cave in the granitic chaos of Huelgoat}

5 The Kerbizien rock-shelter is located in the eastern part of the granite massive of Huelgoat (Finistère) well known for the chaos caused by its erosion when the arenas 
were eroded. They represented an obstacle to human movement on slopes and especially in the valleys, where the rivers run under the huge pile of granite balls. They certainly were favourable shelters, unfortunately much degraded by the action of quarrymen of the nineteenth and twentieth centuries. The eastern part of the Arrée Mounts is high (between 200 and $380 \mathrm{~m}$ ) and the oceanic climate today makes it highly humid; the annual rainfall is $1,400 \mathrm{~mm}$ against $700 \mathrm{~mm}$ on the northern coast. The -50 $\mathrm{m}$ depth contour on the marine charts is 45 miles away to the north, $75 \mathrm{~km}$ at the south and $80 \mathrm{~km}$ on the west: the northern coast is the closest, although the rock-shelter of Kerbizien is found upstream in the watershed of the Aulne, principal river of Central Brittany flowing westward. Hunters of the Late Prehistory therefore invested a hilly area with very original characteristics, high, wet and littered with huge granite boulders. Evaluated in terms of the geography of Brittany, it is far from the ocean, but also from sources of knappable rocks such as flint pebbles or local rocks (Eocene sandstone, cataclasites, ultramylonites, phtanites, chalcedony, microquartzites).

6 The Kerbizien site is located 1,850 m northwest of the church of Huelgoat (Finistère), on the southwest side of a hill, 231 meters above sea level, up to the $190 \mathrm{~m}$ asl curve (fig. 2). The site borders a small trough, little marked, that starts there and does not appear clearly on the maps or on aerial photographs. On a north-south axis, it is too steep and too short $(180 \mathrm{~m})$ to collect a perennial stream, but it offers a very natural circulation corridor towards le Ruisseau des carrières that runs below (altitude $180 \mathrm{~m}$ asl). Opened to the west with a smaller overhang on the southwest, the Kerbizien shelter offers a particularly impressive monolithic appearance (fig. 3, 4 and 5). The cave is dug at the expense of a huge granite block, $6.77 \mathrm{~m}$ high above the current ground level. This block is $19.40 \mathrm{~m}$ long (north-south axis) and $18.20 \mathrm{~m}$ wide (east-west axis); it is used nowadays as a plot limit, inserted in a large stone embankment. The rockshelter measures $9.50 \mathrm{~m}$ at the opening by about $5.50 \mathrm{~m}$ deep (fig. 6, 7 and 8). This is obviously not a karst cave subjected to subsiding phenomena of and the top of the shelter filling is flat, as well as the bedrock, without marked gradient between the inside and the outside. At the entrance, the ceiling height is now $2.80 \mathrm{~m}$ from the bedrock. The wall only reclines at the back, which ensures a good habitability: one meter from the back, the ceiling is still $1.40 \mathrm{~m}$ high. In the Azilian it was roughly the same, the circulation level being only $20 \mathrm{~cm}$ above the bedrock. Four large blocks about two meters long each occupy the north of the cave (blocks 1, 2, 3 and 6); they block off about $11 \mathrm{~m}^{2}$ of the total surface. Only a small space remains between them and the ceiling (for example $12 \mathrm{~cm}$ above block 2 or $35 \mathrm{~cm}$ above block 6). Despite these rocks preventing the occupation of the northern part of the shelter, a standing person still has $16 \mathrm{~m}^{2}$ of rock surface at the centre of the shelter and in front of the blocks to the north, while an additional $4 \mathrm{~m}^{2}$ are still available at the back, if one accepts to bend down slightly.

7 South of the shelter immediately in front of the overhang, two large blocks laid flat occupy the space on a dozen square meters. The largest (block 4) is $3.50 \mathrm{~m}$ long by 2.50 $\mathrm{m}$ wide and $1.00 \mathrm{~m}$ thick from the current floor with a flat upper surface that makes it a very comfortable space to settle in front of the shelter. One can easily imagine a work area that provides a better heat return than the bare soil. It was broken off at the northern end, as evidenced by a clean break, much eroded debitage traces and the pit dug around it. It is difficult to precisely restore the original shape but it could not exceed two extra meters in length because it did not reach the squares of strip L and 
therefore it did not block the entrance to the cave. More recent traces of breakage (three notches for wooden wedges) are also visible in the western part of the block, but the rock was not detached. Block 5 is the same length as the previous one, but it is only one meter wide. Half of it is found under the overhang and makes this area uninhabitable, on the opposite of the previous one. To the west of block 4, the spreading of a portion of the rock-shelter filling in the 1980s makes a very noticeable waste accumulation.

An area of about $4 \mathrm{~m}^{2}$ is also protected and easily accessible south of the monolithic block of the shelter, at the height of strips $F$ and $G$, although less than a meter high under the ceiling and very narrow (a little over a meter). The ground in this area is higher than elsewhere because it was not disturbed by the work. This small hill corresponds to a loess accumulation south of the main block, probably when northern winds blew in the Ice Age. These wind sediments were blocked up about five meters to the south by another granite block more than $10 \mathrm{~m}$ long, low above the current ground (fig. 6). Despite its small size, this sheltered area was occupied in the Azilian and the Mesolithic, unfortunately mixed up in the current soil, with relatively sparse lithic objects.

The beautiful living volume of the cave and its monolithic nature make it a quite exceptional habitation place at the local scale (fig. 8): our many visits to the chaos around - certainly all very amputated by quarries - did not reveal anything similar. Its high position in the landscape and its opening to the west were probably also important parameters in the choice of the location, while the distance to the river must have been a constraint that was obviously solved.

Figure 1 - Location of the azilian sites (Curve Backed Points) and post- azilian sites (Straight Backed Points) on the Armorican Massif. The black star corresponds to the Kerbizien rock shelter (CAD: G. Marchand).

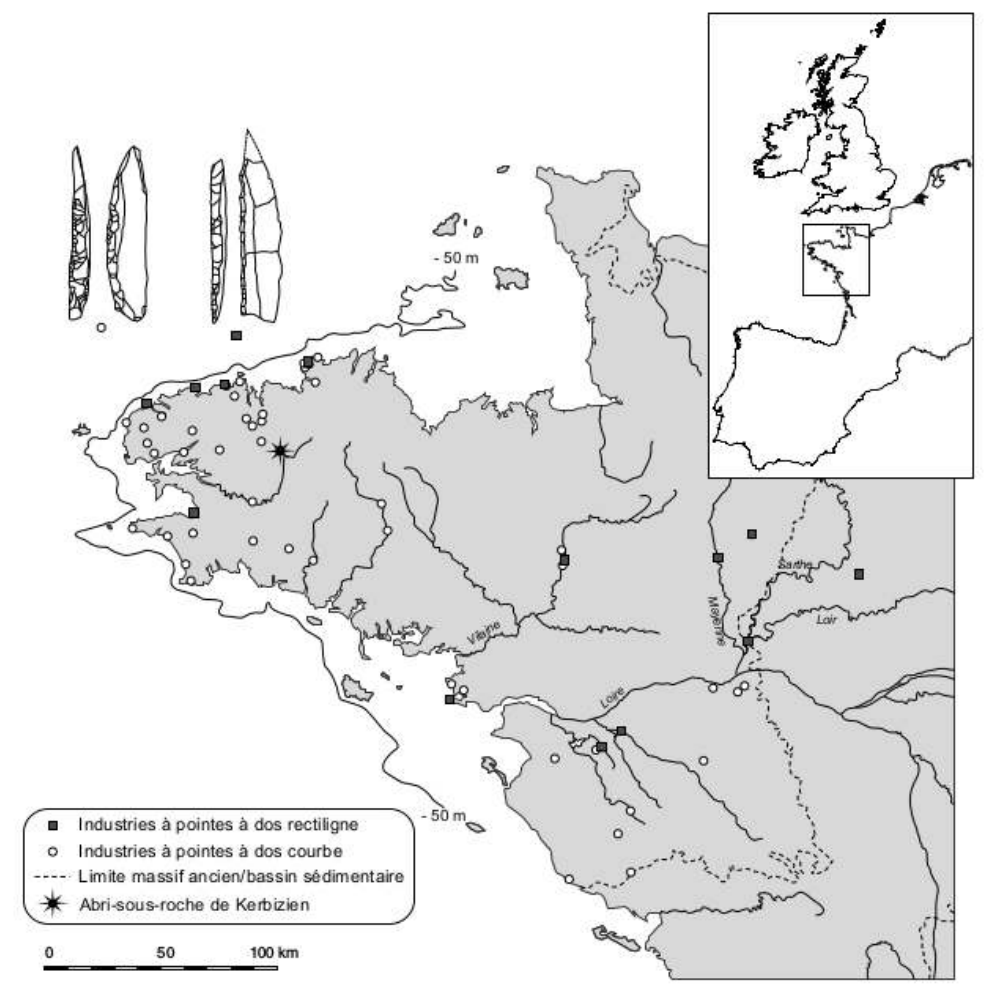


Figure 2 - Location of the Kerbizien rock shelter in the eastern Arrée Mountains (map: IGN géoportail).

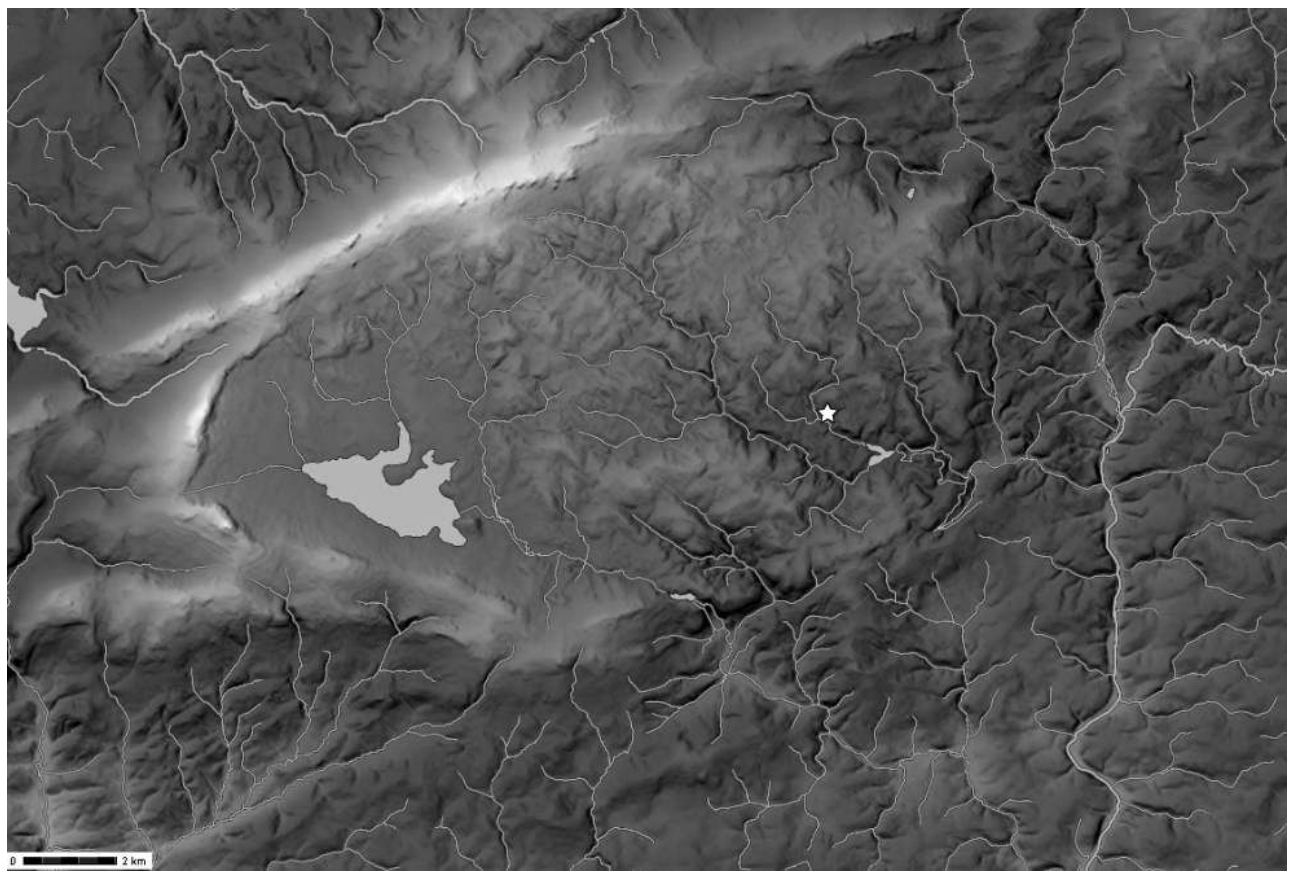

Figure 3 - The Kerbizien rock shelter during the years 1980 before the partial destruction of the prehistoric layers (Picture: A.-M. Mazurier, reworked by F. Bertin).

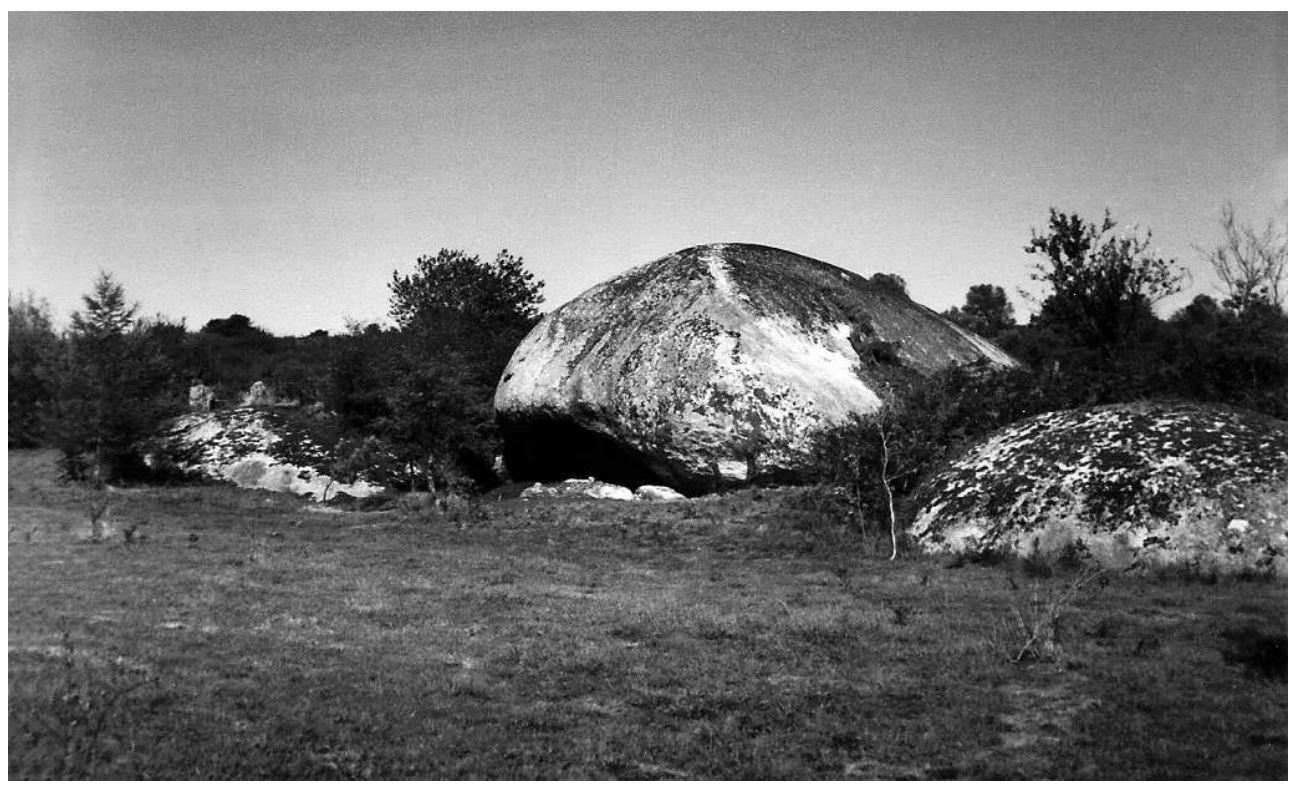


Figure 4 - The Kerbizien rock shelter viewed from the west after the 2011 excavation (Picture: $\mathbf{G}$. Marchand).

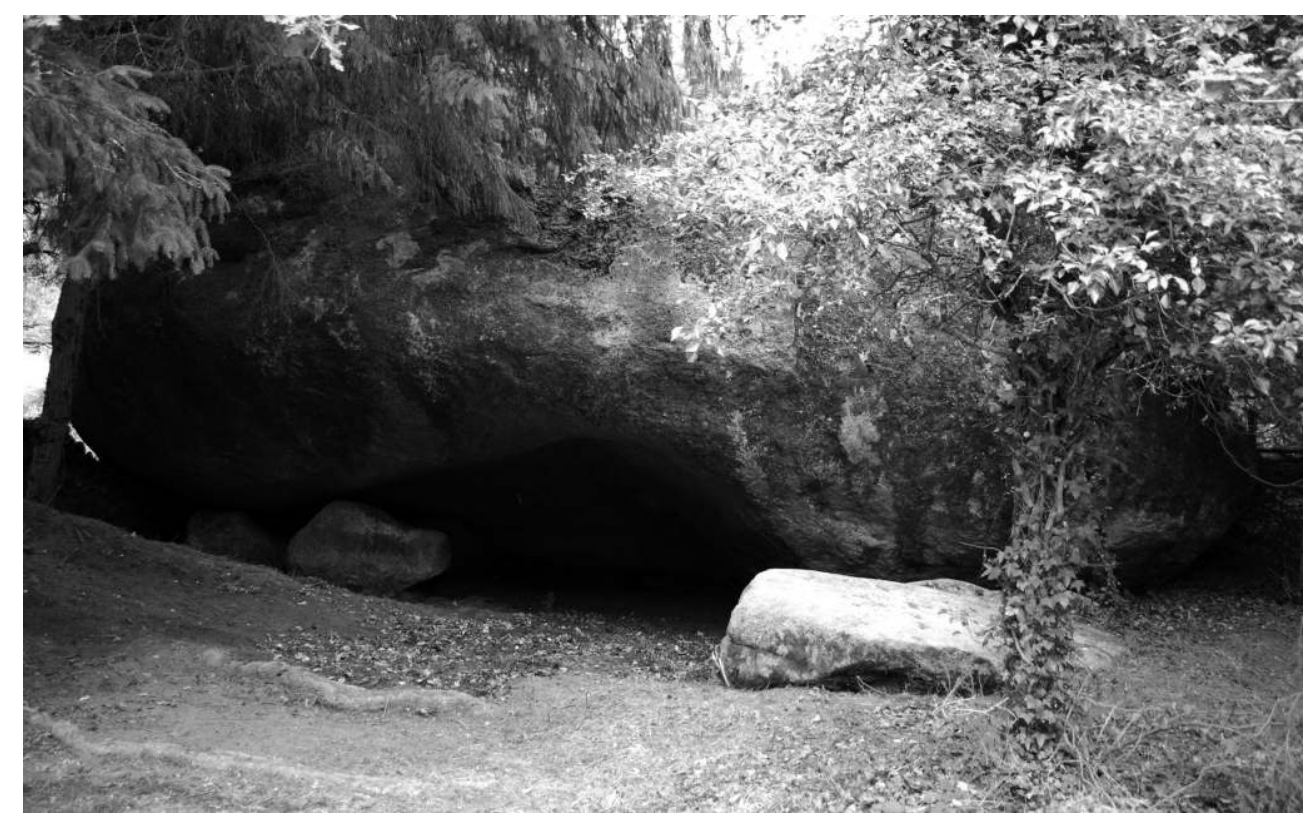

Figure 5 - The Kerbizien rock shelter viewed from the southwest. The loess altered levels appear significantly in the north of the section. The radical truncation of these levels by the mechanical scrapping is also evident in the top of the trench (Picture: G. Marchand).

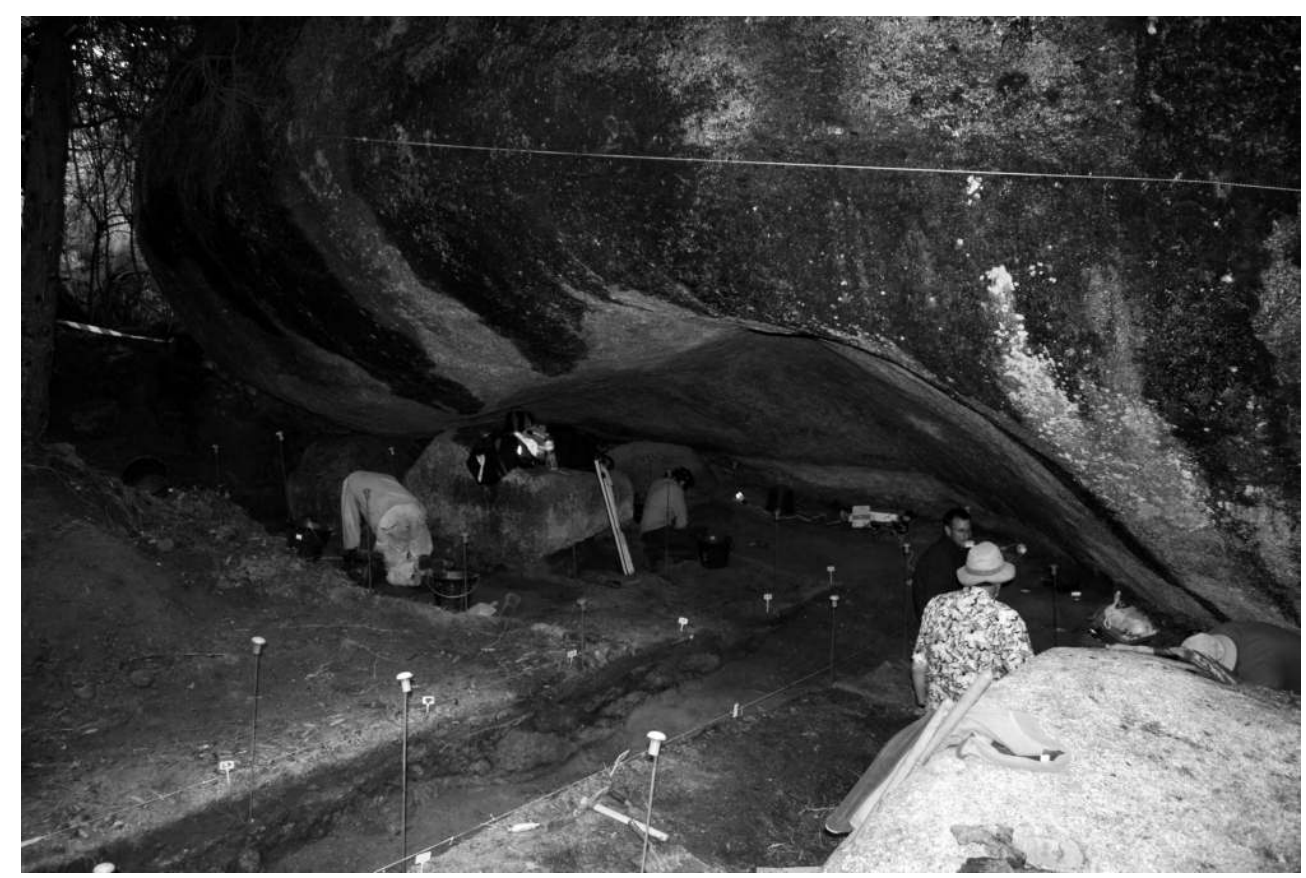

\section{2 - Destruction and incomplete rescue in the 1980s}

Kerbizien became known to archaeology thanks to Jean-Michel Moullec, who took action in the early 1980s to stop the destruction of the infill of the cave. The infill of the shelter had largely been damaged by bulldozing and its contents spread onto the surrounding ground to flatten it and emphasise the overhang in a landscape 
perspective. In the waste soil from the garden, J. M. Moullec observed a large quantity of knapped stone artefacts, mainly of Mesolithic age, as well as abundant slag. A rescue survey was carried out by this researcher in 1984 after authorisation of the Regional Department of Archaeology and a new sieving campaign of the waste soil was done in 1985 (Moullec 1984, 1985). On this occasion, in a small $50 \mathrm{~cm}$ large square located along the back wall (matching our squares L3 and K3), he was able to detect a visibly intact sandy level and suggested at the time to consider the deposit as partially preserved, although this recommendation was not heard in the archaeological community who considered the infill as irreparably destroyed. These comprehensive reports were never published. Like the rock-shelter of Pont-Glas in Plounéour-Menez (Finistère; Le Goffic 1990; Marchand and Le Goffic 2009; Marchand et al. 2011b), Kerbizien became the paragon of Mesolithic settlements under rock-shelters in Brittany (Gouletquer et al. 1996, 1997), while being somewhat forgotten in recent research, which can only be regretted regarding the collected material.

11 In both survey reports made by J.-M. Moullec in 1984 and 1985, a total of 2,940 lithic objects were mentioned:

- In 1984, 1,248 artefacts in the partially sieved waste soil and 660 collected by the owner of the site (J.-J. Mazurier);

- In 1985, 1,032 additional artefacts in the waste soil or the reworked soil of the shelter, including 46 in the small survey pit at the back.

The wide range of metamorphic and sedimentary rocks of the Armorican Massif was identified. J.-M. Moullec's report noted 15\% of chalcedony (now called Clos chalcedony) and $9 \%$ of microquartzite from La Forest-Landerneau. Microgranite (cataclasite from Mikaël) and phtanite are also reported. The remaining objects are made of flint. In J.-M. Moullec's numerous plates, several chrono-cultural components were obvious:

- The final Palaeolithic (Azilian), in the form of very numerous Azilian points, endscrapers on blades and laminar debitage from two opposite striking plans;

- The Early Mesolithic (Bertheaume group, dated today from the interval 8,200-7,500 BC), with narrow scalene triangles and many narrow backed bladelets;

- The Late Mesolithic (Téviecien, dated to the late $7^{\text {th }}$ and the $6^{\text {th }}$ millennium BC), more discreet but marked by symmetrical trapezoids

- A historical period in which the habitat was used as a metal workshop (many slag and sherds).

13 We could only retrieve a group of 755 lithic objects kept by A.-M. Mazurier, which probably corresponds to her husband's collecting increased regularly and over the years (the rest of the objects is currently impossible to locate). Among the 52 projectiles insets, 10 fragments of curved backed points, 7 narrow scalene triangles and 3 symmetrical trapezoids can be noted. The former are exclusively made of gray flint and are identical to the Azilian objects collected in the excavation, while the other Mesolithic projectile insets were also made of cataclasite, microquartzite from La Forest-Landerneau, Clos chalcedony, Eocene sandstone and phtanite (in order of importance) (tab. 1). 
Figure 6 - General map of the Kerbizien rock shelter (Drawings and CAD: G. Marchand).

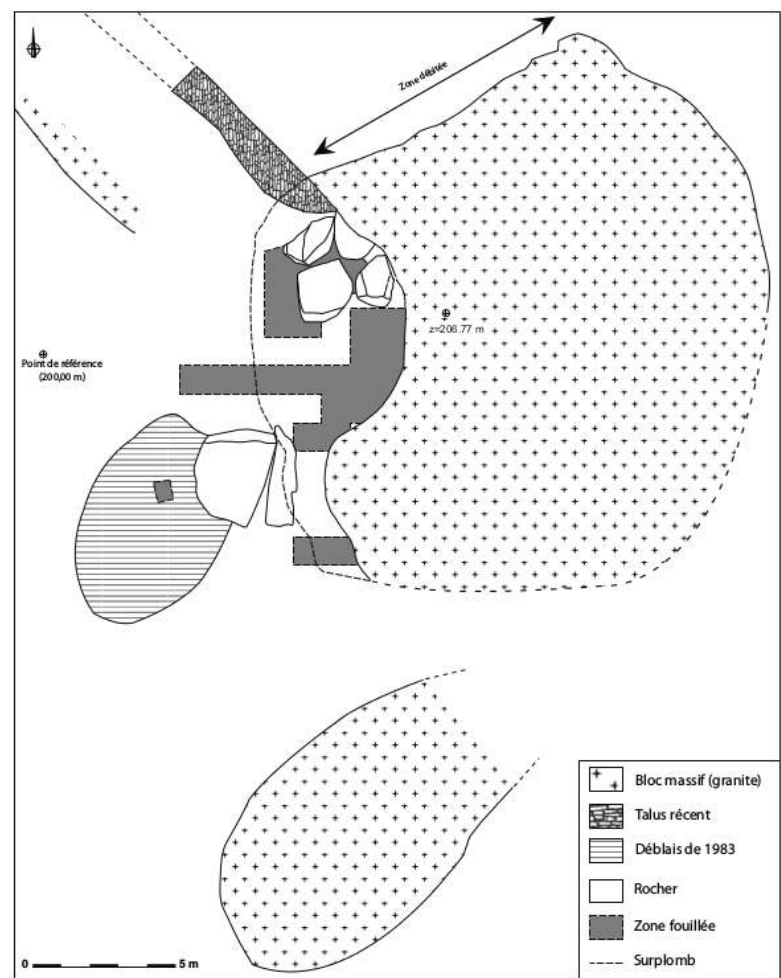

Figure 7 - Map of the excavation of Kerbizien showing the preserved Azilian level inside the rock shelter and by the south of the block (Drawings and CAD: G. Marchand).

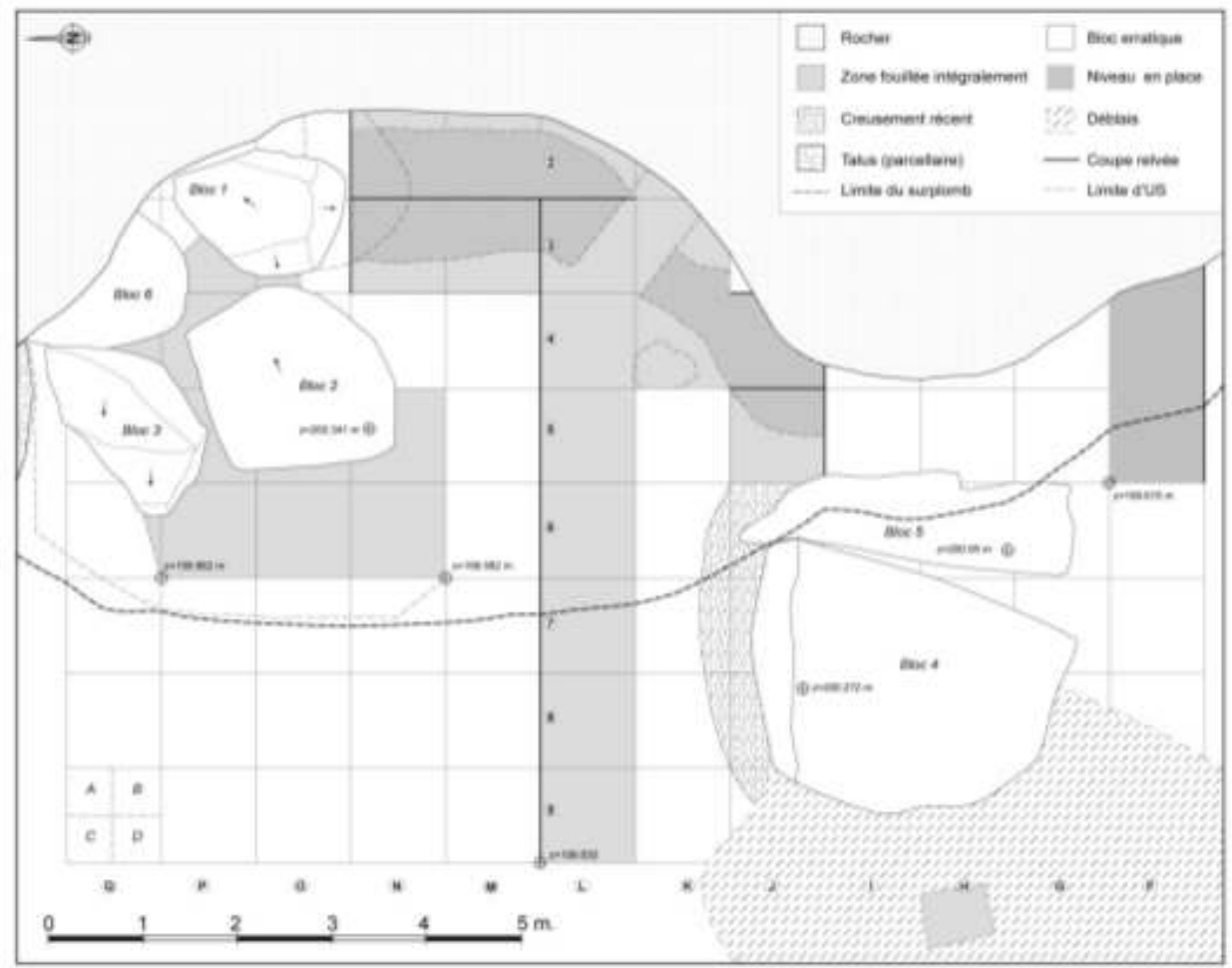


Figure 8 - Profile of the Kerbizien rock shelter (between the bands $L$ and $M$ / north section) (Drawings and CAD: G. Marchand).

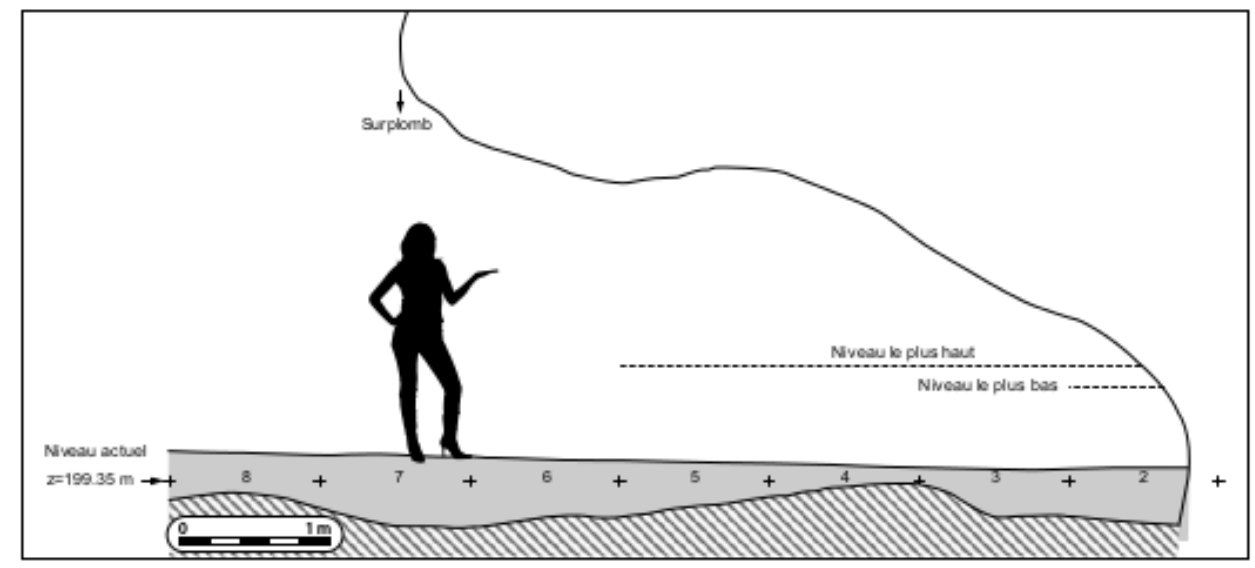

Proal a linesertace LMM (en coupe nond de la bande L)

Table 1 - Scoring of the pieces found out of the stratigraphy by Mazurier.

\begin{tabular}{|l|c|c|c|c|}
\hline \multicolumn{1}{|c|}{ Matière } & Débitage et outillage commun & Armature & $\begin{array}{c}\text { Total } \\
\text { (N) }\end{array}$ & Total (\%) \\
\hline Silex & 456 & 38 & 494 & 65,4 \\
\hline Ultramylonite de Mikaäl & 88 & 1 & 89 & 11,8 \\
\hline Calcédoine du Clos & 68 & 2 & 70 & 9,3 \\
\hline $\begin{array}{l}\text { Microquartzile de la Forest- } \\
\text { Landerneau }\end{array}$ & 60 & 5 & 65 & 8,6 \\
\hline Grès écocène & 22 & 6 & 28 & 3,7 \\
\hline Phtanite & 9 & 0 & 9 & 1,2 \\
\hline Total & 703 & 52 & 755 & 100 \\
\hline
\end{tabular}

\section{3 - Excavation in 2011 of a residual Azilian level}

\section{1 - Excavation set up}

The Late Glacial dimension of the Kerbizien assemblages had not been perceived in the previous research and the study of the shelter was started in the context of a research program on the functioning of the Mesolithic economies. The requirement to add small sites to the already known inventory of settlements seemed imperative to meet, to contrast with the vast open-air sites excavated to date in the region. It had encouraged us to fully excavate the Pont-Glas shelter in 2007 and 2008 (Marchand and Le Goffic 2009; Marchand et al. 2011b), before focusing attention on Kerbizien in July 2011. We aimed to establish a stratigraphic statement, a goal that turned to the complete excavation of the infill when the importance of their degradation was brought to light.

The established metric grid covered the entire overhang, as well as a three meters wide strip at the front. The strips indicated by letters range from $Q$ to $F$, from north to south; the strips marked with numbers range from 2 to 9 , from east to west. A sagittal trench 
(from the back toward the entrance) was first done in strip L, eight meters long (fig. 9 and 10). The south-western part of the block, with its small overhang was also surveyed in strip $\mathrm{F}$ on $2 \mathrm{~m}$ long (F4 and F5 squares; fig. 11). Although the Pleistocene and Holocene levels are nearly $1.20 \mathrm{~m}$ thick, only the upper part comprises lithic remains on about $0.30 \mathrm{~m}$.

Most of the archaeological deposits were removed in the entire cave in the mid 1980s, as our excavations have shown. We were fortunately much luckier in a two metres wide strip all along the back wall, where the thin layer of leaves and dust (the litter - SU 1) directly covered two Azilian stratigraphic units in place (SU 4 and 5). Obviously, it was suitable to distrust the part in contact with the wall where the intense activity of burrowing animals caused a reorganisation of the sediments from top to bottom. The lack of palaeoethnographical interest on such a small surface therefore encouraged us to carry out an excavation by quarter of square meter and by stratigraphic unit. All the soils were water-sieved in barrels on the site or in the stream below, the water used coming from this stream by successive buckets. We used $2 \mathrm{~mm}$ mesh screen (builders' sieve number 12). The large number of splinters collected was the downside of this method.

Consequently, at the end of two weeks of intensive work, we can consider that the Kerbizien rock-shelter no longer contains archaeological levels, whether in place or not. Only the southern part, south of blocks 4 and 5 and outside, still contains remains, but with a sparse distribution and obvious mixing between occupations in the upper horizon of the present day soil. It would seem quite interesting to make at least one trench with a mechanical digger across the small valley, in the continuation of our strip L. Lithic remains from the destroyed stratigraphy of the shelter would certainly be found there, but also from other silty levels that might have recorded occupations since the Palaeolithic. But this project is obviously not valid, because of the garden of the current property.

Figure 9 - Stratigraphic sections in the Kerbizien rock shelter. Bottom: north section of the $L$ band, with loess silt mixed with granitic sand. Top: section of the squares $\mathrm{J} 4$ and J5 in the southwest corner of the cave, in an area of water running along the rock. The Azilian industries were in the 8 and 11 stratigraphic units (Drawings and CAD: L. Quesnel and G. Marchand).
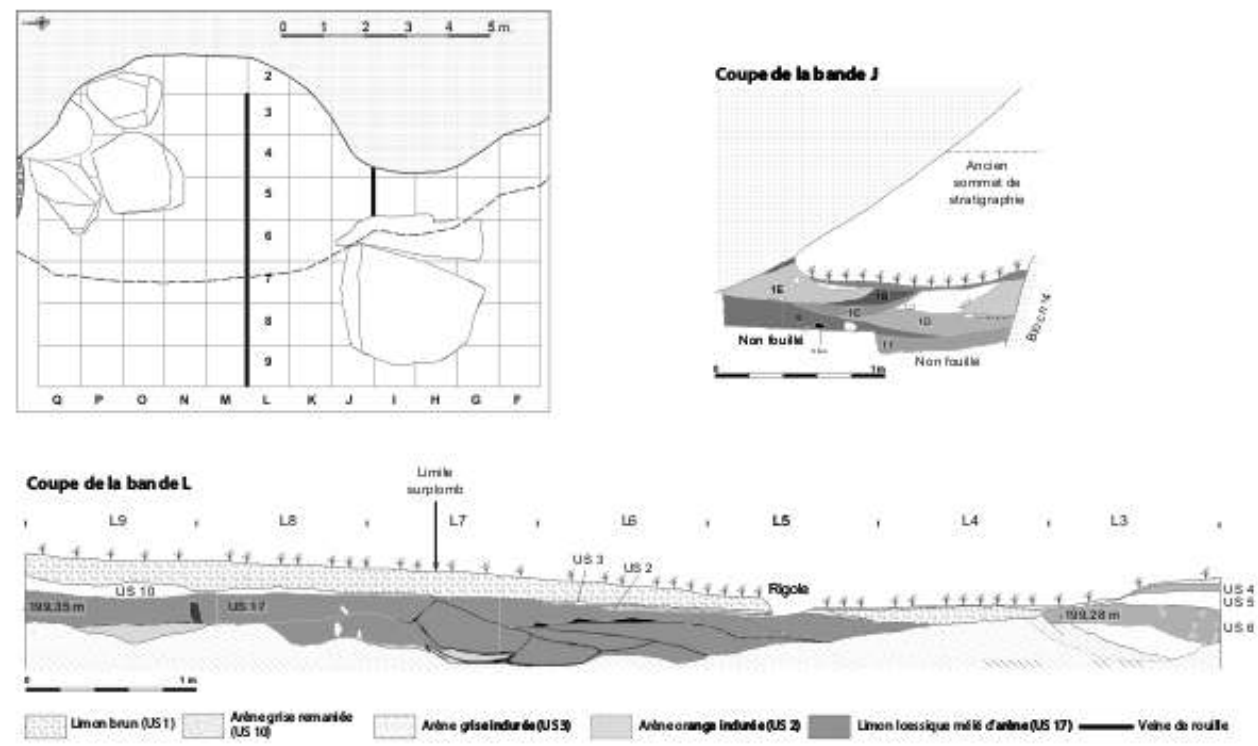
Figure 10 - Stratigraphic records made in the Azilian bead up at the bottom of the cave. The azilian industries were up in the 4, 5 and 6 US (summit) (Drawings: G. Marchand; CAD : L. Quesnel).

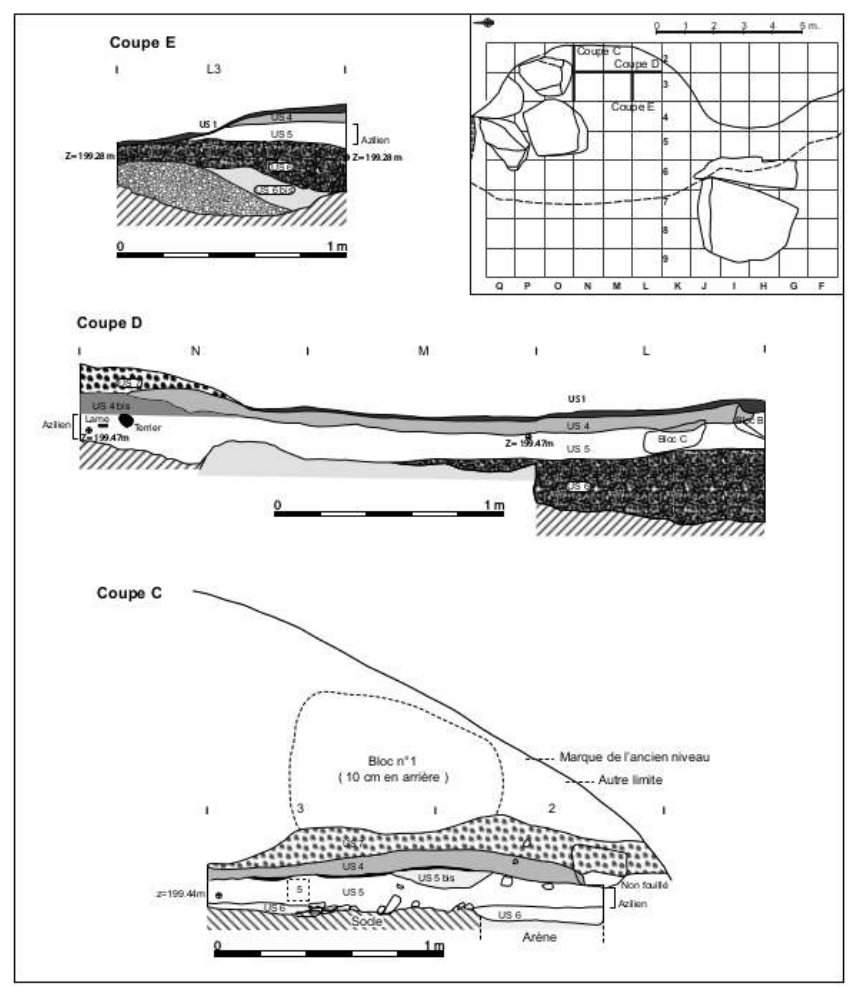

Figure 11 - Stratigraphic record of the southern section of the F band (F4 and F5) (Drawings: G. Marchand; CAD : L. Quesnel).

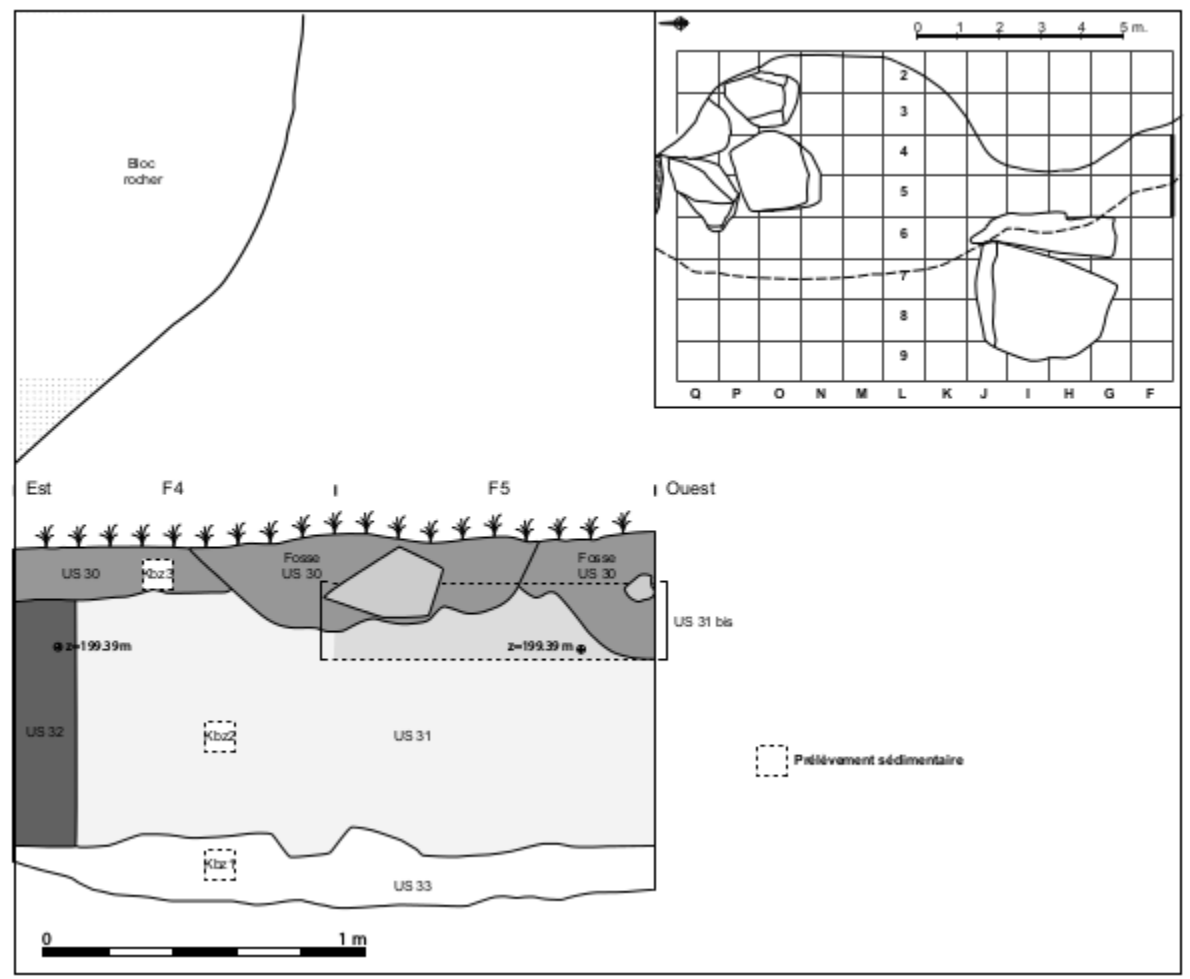




\section{2 - Description of the stratigraphic units}

Huelgoat's granite is a medium and large grained rock, light gray to dark gray-blue, with potassium-Feldspar megacrystals and with euhedral cordierite. As we have observed, the large blocks erode as "onion skins", with neat breakage surfaces opposed to the air-exposed surfaces. The acidity of the soils issued from such a substrate is obviously to be reminded, as it only allowed the preservation of mineral remains and charcoals. This granite arena resulting from erosion is the primary source of increase of the filling of the cave. Outside, it is complemented by dust and vegetal deposits in the Holocene and by loess silt in the Pleistocene.

Two neat superimposed horizontal lines, spaced $18 \mathrm{~cm}$ apart on all the walls of the cave, indicate two successive states of the destruction of stratigraphy, a meter thick on average at the most. Nobody can confirm it was of good quality and free of disturbances, but the abundance and functional variety of the collected lithic allow evoking large scale Mesolithic settlements, well differentiated from those recorded at the small Pont-Glas station. The succession of the stratigraphic units in the rock-shelter is thus severely truncated and one can only describe its basal part, accessible immediately under a thin litter of leaves and dust (the waste soil was spread outside the shelter). Inside the cave, a rim consisting mainly of granitic arena had not been disturbed (SU 4, 5 and 6); this constitute the happy surprise of the survey, the subject of this article. It extends into what we will call here the "angle of the shelter" (squares J4 and J5), very affected by the water flowing on the wall, but definitely in place and stratified. In this cave, the SU 31 and 32 correspond to a twenty centimetres wide strip running along the wall. Enriched in organic matter by water flows and the countless burrows dug since the dawn of time, they are mixed areas where objects of all periods abound.

In front of the main shelter, the layer sequence is affected by a very slight slope from the outside to the inside of the shelter (fig. 9 and 10). There is also a very slight slope from north to south, which corresponds to the slope of the hill, but it should be noted that blocks 4 and 5 stopped the sediments and prevented the Pleistocene and Holocene sedimentary deposits from slipping. If such a configuration was able to stabilise sediments over the centuries, it was not effective against the assaults of a mechanical digger... Almost all of the archaeological filling was swept away... A level much packed by the work of the 1980s and marked by numerous fires (SU 1) overcomes a loess silt level (SU 17), that we excavated up to the bedrock on the entire length of the trench, with an average depth of $0.40 \mathrm{~m}$, without any archaeological discovery. Thus, this beautiful Pleistocene level is not precisely dated. It shows a complex combination of wind silt (loess) and granitic sands, with large rusty lines related to iron migration along roots passages. Twenty centimetres thick, the level rests on the bedrock without transition, suggesting an exposure before the loess deposition and therefore a possible leaching of the previous archaeological levels. This could explain the absence of Palaeolithic remains before the deposition of the wind silt. So the possibility of an archaeological occupation record in this SU 17 is there, but our work did not show it existed.

- South of the monolithic block (strips $G$ and F), the sedimentary deposits have not been truncated by the works and the building up of a soil (in the pedological sense) on a loess silt 
enriched by granitic sand can be observed (fig. 11). $1.20 \mathrm{~m}$ thick, they are completely free of remains, just as the front of the shelter, confirming the absence of settlement in the Pleniglacial in this rock shelter. Can be observed from bottom to top:

- A very hard level of silt and granitic sand, yellow (SU 33 - sample Kbz1);

- A yellow-orange very fine silt, 0.80m thick (SU 31 - sample KBZ 2);

- A brown organic silt corresponding to horizon A of the current soil (SU 30 - sample KBZ 3).

- The wall effect at this place was named SU 32.

In conclusion, among the areas in place, which of course are more interesting for us, we can distinguish:

- The back of the shelter (squares N2, N3, M2, M3, L2 and L3);

-An area of "gutter" at the corner of the shelter, extremely rich in objects (including Azilian points - squares J4 and J5);

- The area south of the block (squares of strip F).

\section{3 - The Azilian levels}

\subsection{1 - The bench at the back of the shelter}

A bench of granitic sand had been preserved at the back of the shelter and its exploration was facilitated by a permanent stratigraphic control in the section of the small survey pit done by J.-M. Moullec, then by several frontal and side sections during hand digging. The bench in place was covered up whether by a litter of halfdecomposed leaves and dust (SU 1), whether by waste from burrows in squares N2 and N3 (SU 7). SU 4 appeared after a quick and easy surface clean up (fig. 12). This very compact orange arena was $5 \mathrm{~cm}$ thick in squares $\mathrm{L}$ and $\mathrm{M}$; it thickened up to $10 \mathrm{~cm}$ in $\mathrm{N}$. Obviously, we cannot say how much of it was destroyed in the 1980s. The lower level (SU 5) also showed a largely dominant sandy matrix, slightly browner than the previous one, $10 \mathrm{~cm}$ thick. A slightly thicker gravel level materialized the base; the rock was also trampled in N3 B. SU 5, like SU 4, is a very compact level. An exclusively Azilian lithic industry was discovered in SU 4 and SU 5, on a total thickness of $15 \mathrm{~cm}$.

Granite blocks with decimetric dimensions appeared in the two SU, one of which had its base in SU 4 (N2-3), the others were rather placed at the base of the SU 5 (squares M2, M3 , N2 and N3), three others - especially remarkable - were placed at mid-height of the SU 5 in squares K3, L3 and L2 (fig. 13 and 14). These were called A, B and C (fig. 15). Block B had already been discovered by J.-M. Moullec in his survey pit and conveniently left in place. Their handling by humans is undoubted: they not only had their tearing face lying on the floor, which implies that they were turned over, but they also bear clear traces of debitage. No hammer was found nearby. Four other blocks of granite between 10 and $25 \mathrm{~cm}$ long were lying $30 \mathrm{~cm}$ to the south (square K3), alas immersed in SU 31 (wall effect). This time, they had not been knapped.

The collected archaeological material includes knapped rocks to make tools (flint, Eocene sandstone, microquartzite from La Forest-Landerneau and Clos chalcedony), and also small shale plaquettes and millimetric shale fragments.

Some charcoals were collected in the SU 4 and 5, but they are rare and unreliable. According to Nancy Marcoux, an anthracologist at the University of Rennes 1, these charcoals also seem rather fresh, therefore recent, under the microscope. A fragment of hazel twig, recovered in the SU 5 square L2, sub-square D (at the height of the 
granite blocks), was nevertheless sent for dating by the radiocarbon method to BetaAnalytic. The result is $5,220 \pm 40 \mathrm{BP}$ (Beta-306 993), that is to say a 1 sigma dating between 4,040 and 3,980 $\mathrm{BC}$. This value is far too recent compared to our expectations and not correspond to a Middle Neolithic occupation in the archaeological material, even in the mixed up levels. We can nonetheless report a large trapezoidal bitroncature in flint (K3A-US13), interpreted as a cutting arrow from that time. The proximity of the wall effect that contaminated the area is probably the cause of this disappointing dating, as micro-charcoals migrated according to the movements of burrowing animals and water circulation.

The Azilian layer was lying on an equally sandy orange to lemon yellow layer, much less compact, or more rarely on the bedrock (M3 square; sub-square A, C and D). The SU 6 has yielded in N2 D a pocket of aeolian silt, an evidence that the sandy level does not correspond to the rock disintegrating in place, but rather to the accumulation of the grains falling from the walls, that mingled with the silt. The SU has delivered lithic only in its upper part, without evidence of previous occupation. It appears to be thicker near the back wall, which seems to result from an erosive process. When the Azilian occupants arrived in the cave - for what we can judge in the deepest part - they settled whether on a coarse sand, whether more rarely on the bedrock. Strip 2 was not directly suitable for human occupation, except for sleeping, because of the inclination of the wall; the discovered archaeological material could have been deposited due to "kicking" or abandoning waste on the periphery of the activity areas.

Figure 12 - Bottom of the Azilian level in the M3 and N3 squares (picture: G. Marchand).

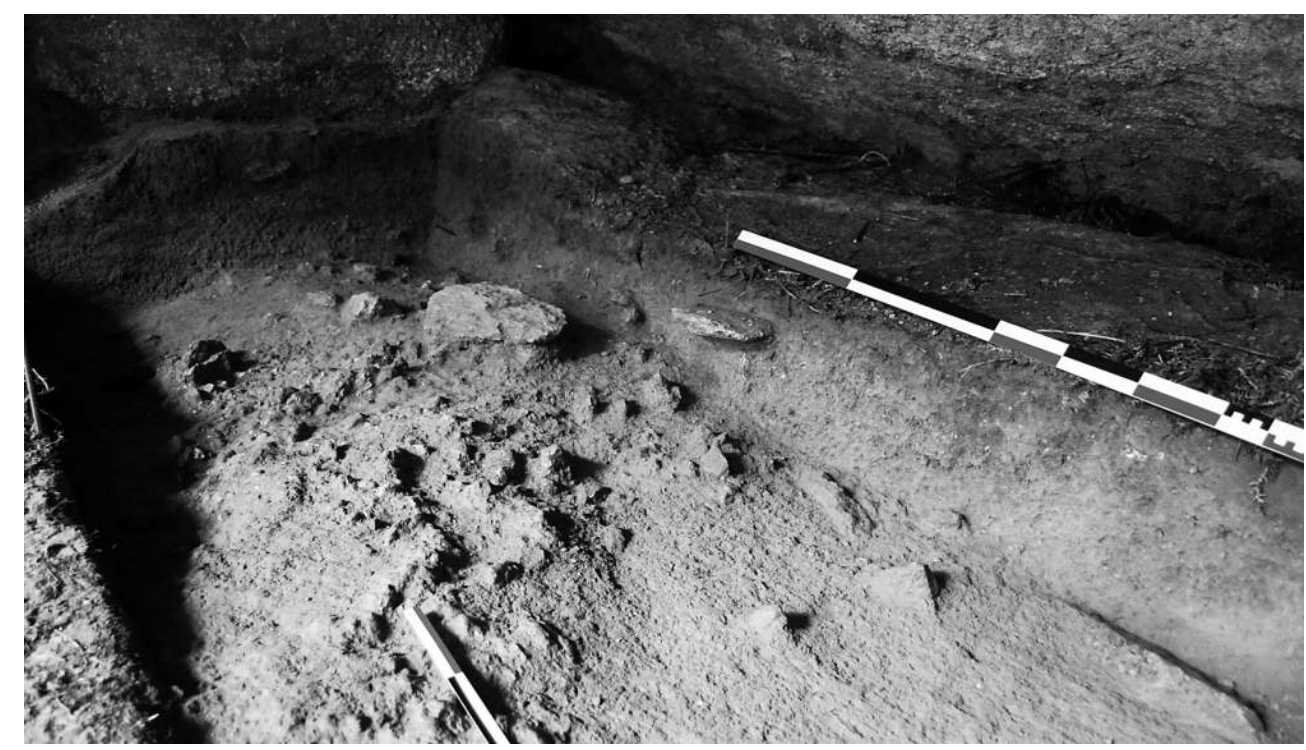


Figure 13 - Southern part of the rock shelter. The A, B and C granite blocks are visible on the upper part of the deep survey (picture: G. Marchand).

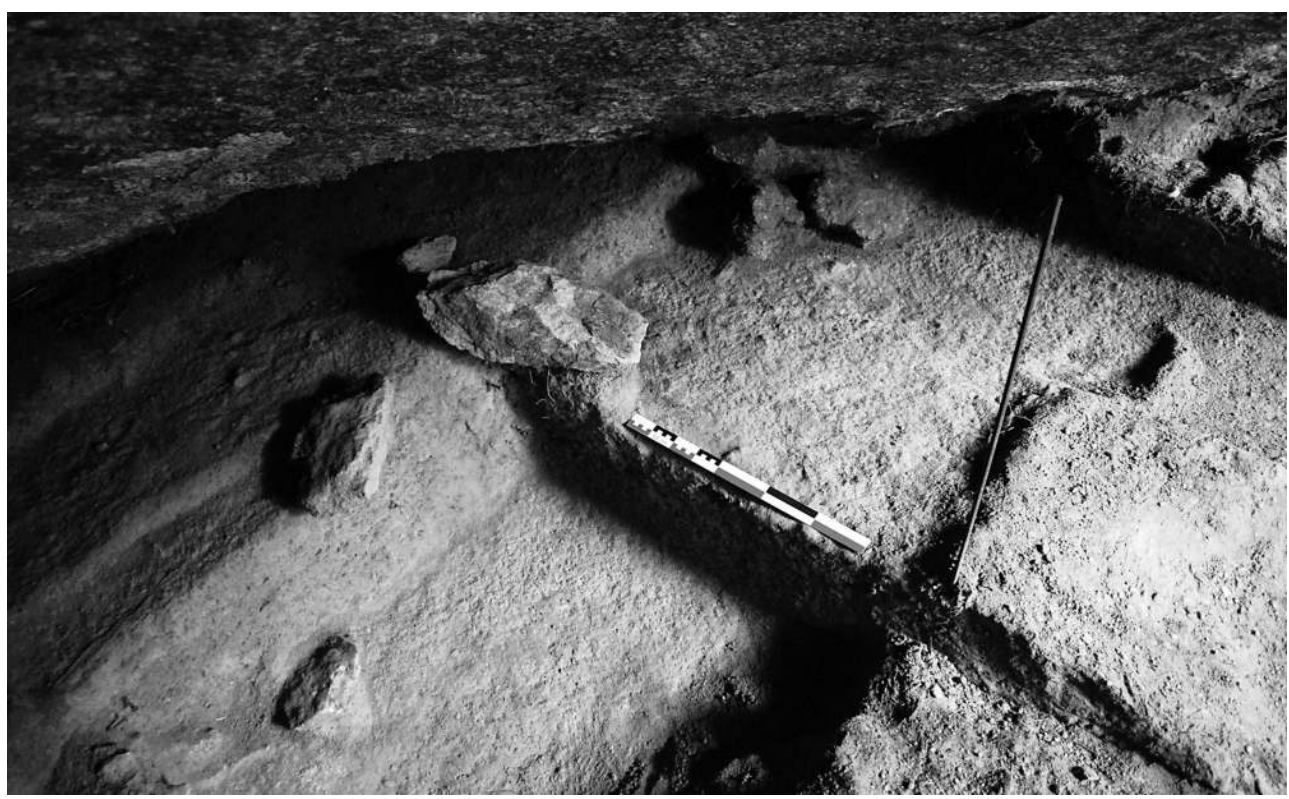

Figure 14 - Plan of the bottom of the Azilian layer in the N2, N3, M2 and M3 squares (CAD : L. Quesnel).

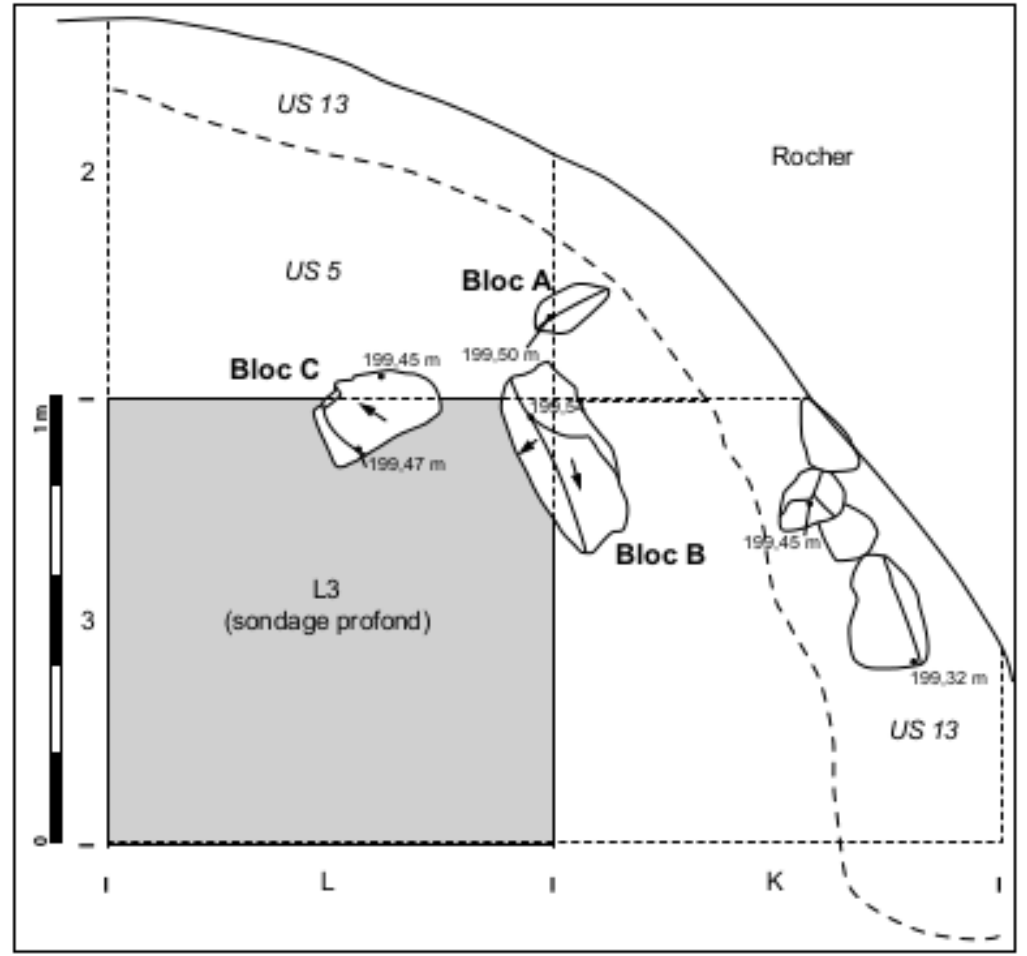


Figure 15 - Plan of the bottom of the Azilian layer in the L2, L3, K2 and K 3 squares, with the granite blocks A, B and C (CAD: L. Quesnel).

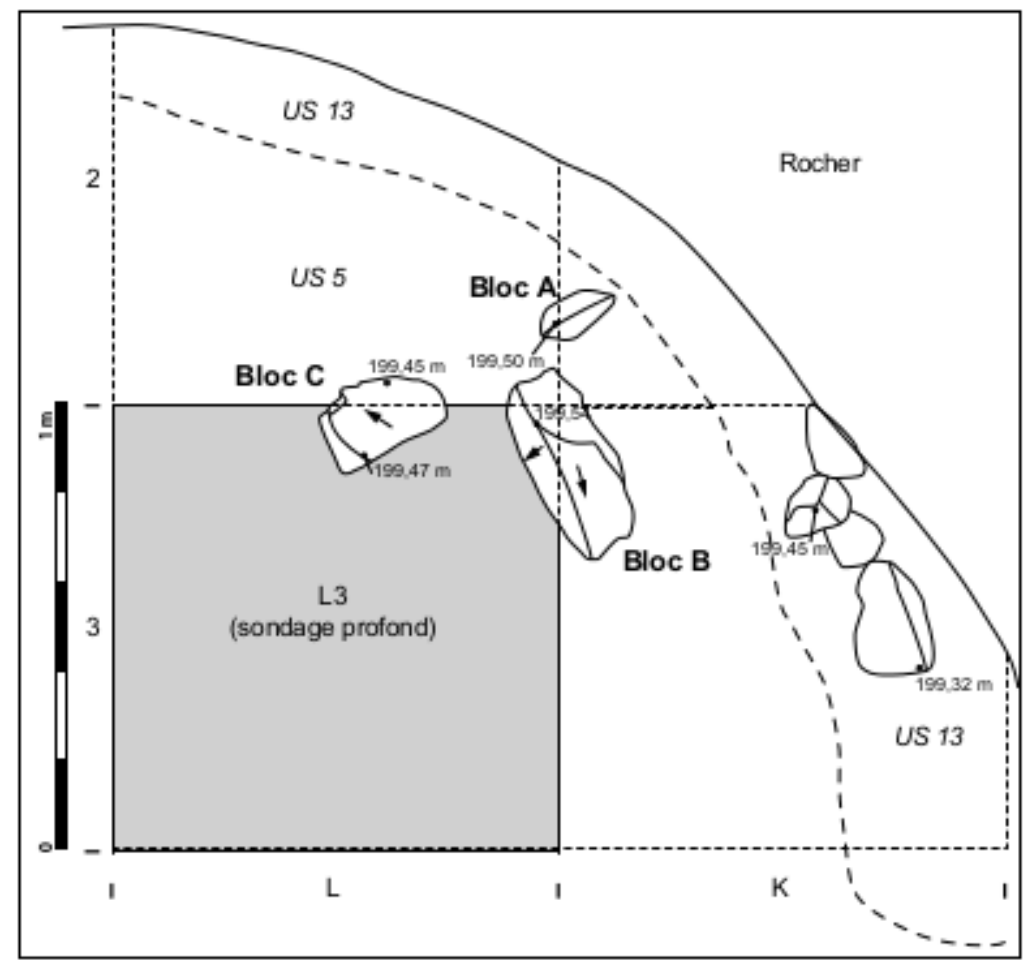

\subsection{2 - The angle of the shelter (J4-J5)}

The excavation of the angle of the shelter gave us a lot of hard time because it is an area where runoffs from rainfall (locally very abundant in July 2011) concentrate naturally, because of the bulging rock. It required many contortions due to the low ceiling and was only truly understood by its stratigraphic sections at the end of the exploration. The inclination of the wall and the water flow make the occupation difficult, which obviously helped its relative preservation in the drastic changes of the 1980s. Yet this is where the density of lithic is the strongest, especially for the Azilian points. The stratigraphic units are inclined from north-east to south-west, that is to say from the inside to the outside of the shelter and towards block 5. This is an area of "draining" in the spatial logic proper to the cave. The stratigraphy consists from bottom to top (fig 9. above):

- Artefact-free sand (SU 15);

- Sand 11 devoid of remains except at the top (but very few objects);

- A black sand, overloaded with organic matter, which contains the Azilian flints (SU 8), $15 \mathrm{~cm}$ of maximum thickness and bevelled outward; its hardening is probably due to the concretionning of iron,

- A series of sandy layers $(1 \mathrm{~B}, 1 \mathrm{C}, 1 \mathrm{D})$ truncated by a small drainage channel (1F and $1 \mathrm{G})$ in square F5, which sums up in a single SU (1E) towards the inside in square F4.

Direct correlation between the latter and the preserved bench at the back of the shelter is easy (SU $11=\mathrm{SU} 6$; SU $8=\mathrm{SU} 5$; SU $1 \mathrm{D}=\mathrm{SU} 4)$. 


\subsection{3 - Trench F}

- The prehistoric levels are also preserved in the south-eastern part of the monolithic block, but within a well developed current soil. One can distinguish from bottom to top from the rock (fig. 11):

- A very hard level of silt and granitic sands, yellow (SU 33);

- A very fine yellow-orange silt, $0.80 \mathrm{~m}$ thick;

- An organic brown silt (horizon A of the current soil).

A brown strip of silt mixed with sand existed along the wall, about $0.20 \mathrm{~m}$ wide; it corresponds to a much disturbed area due to burrowing animals and infiltrations. Two successive excavations disrupted the higher humic horizon. The Mesolithic remains (including two trapezoids) come from the pit in square F5 (sub-square D). The Azilian points were found at the top of the aeolian silt in SU 31. It seems inappropriate to conclude that the loess (usually dated to the Pleniglacial) were deposited at the same time than the Azilian points (usually dated to the Alleröd), but rather that there was a shifting of the loess in the late Pleistocene and Holocene.

\section{4 - Sedimentological interpretation}

Five samples of 10 by $10 \mathrm{~cm}$ on a depth of $5 \mathrm{~cm}$ were made in the sections for granulometric analysis. They were carried out at the University of Rennes 1 by two of us (JLM and FP). In trench F, the three samples taken from the three sedimentary units show at the base a sandy loess mixed with sand on 20-25 cm thick (SU 33 - tabl. 2), gradually increasing in sand and organic matter (SU 31) up to the upper humus horizon rich in organic matter and much less sorted (SU 30) (fig. 16 to18).

In the trench of strip L, a sample was taken in the SU 17 (Kbz4), outside the veins of iron oxides crossing the yellow silt. The sedimentological analysis revealed loess containing rare gravels. At the bottom of the shelter in square N3, SU 5, which contains the Azilian remains, shows conversely a low silt level and a formation by progressive fragmentation of the rocks nearby. The morphoscopic examination reveals that the whole of the quartz are not worn and come from such a contribution (tabl. 3 ).

Because of the major truncation of the Holocene deposits, we will focus on the discovery of loess deposits in front of the shelter and especially south of the rock, in the form of a slight ridge. Obviously, this position would be consistent with a wind contribution from the shores of the Channel to the north, over the Arrée mounts. Apart from the purely archaeological aspects, highlighting an evidence of the eroded loess cover is interesting in that it shows the southward extension of the loess contributions from the Weichselian Upper Pleniglacial (MIS 2). The sedimentological study of the composition of the Armorican Bronze Age mounds already addressed this issue on the northern fringe of Brittany (Briard and Monnier 1976), in areas where the loess deposits are not mapped. The mechanism of these contributions during the coldest phases of the last glacial are now better known (Lefort, Monnier, and Danukalova forthcoming). There is such a covering in the vicinity, for example along a dirt road leading to the village of Kerbizien, $130 \mathrm{~m}$ southeast of the shelter.

There was a probable draining of the archaeological levels and an exposure of the rock before the loess deposit as a direct superposition is observed without transition. At that time, the Kerbizien shelter was not occupied by humans. The first Azilian settlement, at 
the end of the Bölling or at the beginning of the Alleröd, is recorded in the levels of disturbed sands within the shelter and in a current soil consisting at the top of repositioned loess, southwest of the block. The major mechanical truncation in the 1980s prevents further description of the sedimentary history of the site in the cave. Moreover, in the southern part, there was no significant sedimentary covering as the contribution from the disintegration of the rock was not sufficient to produce a matrix capable of distinctly include the remains of the Mesolithic and the Late Palaeolithic.

Table 2 - Sedimentological analysis of five samples (J.-L. Monnier et F. Pustoc'h).

\begin{tabular}{|c|c|}
\hline Nom & Description \\
\hline $\begin{array}{l}\text { Kbz1 } \\
\text { (US 33) }\end{array}$ & $\begin{array}{l}\text { Sédiment à texture limoneuse, couleur : humide 10YR5.5/6 (brun jaune) - sec 10YR6/5 (brun jaune clair) - présence } \\
\text { de sable et graviers (altération granitique) - assez bon classement autour de } 35 \text { microns et bonne symétrie de la } \\
\text { courbe }\end{array}$ \\
\hline $\begin{array}{l}\text { Kbz2 } \\
\text { (US 31) }\end{array}$ & $\begin{array}{l}\text { Sédiment à texture limoneuse, davantage de graviers - couleur : humide 7.5YR4 .5/4 (brun) - sec: 10YR5/3 .5 (brun } \\
\text { à brun-jaune) - un peu moins bien classé. Très riche en matière organique }\end{array}$ \\
\hline $\begin{array}{l}\text { Kbz3 } \\
\text { (US 30) }\end{array}$ & $\begin{array}{l}\text { Sédiment à texture limoneuse, présence de graviers (idem à Kb22) - Couleur : humide 10YR3.5/6 (brun jaune } \\
\text { sombre) - sec : } 7.5 \text { YR4 } .5 / 3 \text { (brun) - moins bien classé que les précédents - beaucoup de matère organique }\end{array}$ \\
\hline $\begin{array}{l}\text { Kbz4 } \\
\text { (US 17) }\end{array}$ & $\begin{array}{l}\text { Sédiment à texture limoneuse, très peu de graviers et sable - couleur : humide : } 7.5 \text { YR } 4.5 / 6 \text { (brun soutenu) - sec: } \\
\text { 10YR6,4 (brun jaune vif) - assez bon classement }\end{array}$ \\
\hline $\begin{array}{l}\text { Kbz5 } \\
\text { (US 5) }\end{array}$ & $\begin{array}{l}\text { Sédiment à texture sablo-limoneuse, beaucoup de graviers (arène granitique) - couleur : humide : } 10 Y R 5 / 6 \text { (brun } \\
\text { jaune) - sec: } 10 \text { YR5.5/4 (brun jaune vif) - assez bon classement }- \text { courbe de } 50 \text { à } 20000 \text { microns : médiocre } \\
\text { classement ( } \mathrm{Hq}=3, \mathrm{Md}=1600 \text { microns) et forte asymétrie (Asq = 3,3), }\end{array}$ \\
\hline
\end{tabular}

Table 3 - Morphoscopy : test on the 5 samples (500-400 microns : NU à 100\%).

\begin{tabular}{|c|c|c|c|c|c|c|c|c|c|c|c|c|c|c|c|}
\hline Échantillon & $\begin{array}{c}\% \\
\text { L\&A }\end{array}$ & $\begin{array}{c}\% \\
\text { S }\end{array}$ & $\begin{array}{c}\% \\
\text { G }\end{array}$ & $\begin{array}{c}\text { A text } \\
\text { L }\end{array}$ & $\begin{array}{c}\% \text { text } \\
\text { L }\end{array}$ & $\begin{array}{c}\text { Stext } \\
\text { S }\end{array}$ & $\begin{array}{c}\text { Q25 } \\
(\mu)\end{array}$ & $\begin{array}{c}\text { Q50 } \\
(\mu)\end{array}$ & $\begin{array}{c}\text { Q75 } \\
(\mu)\end{array}$ & $\begin{array}{c}\text { Q25 } \\
(\alpha)\end{array}$ & $\begin{array}{c}\text { Q50 } \\
(\alpha)\end{array}$ & $\begin{array}{c}\text { Q75 } \\
(\alpha)\end{array}$ & $\begin{array}{c}\text { Hq } \\
\text { Asq }\end{array}$ & $\begin{array}{c}\text { NU } \\
\%\end{array}$ \\
\hline Kbz1 & 64,0 & 27,3 & 8,7 & 2,9 & 68,4 & 28,7 & 18,04 & 34,80 & 53,31 & 17,44 & 14,58 & 12,73 & 2,3 & $+0,5$ & 100 \\
\hline Kbz2 & 57,7 & 28,0 & 14,3 & 3,2 & 61,7 & 35,1 & 16,47 & 36,41 & 62,28 & 17,83 & 14,39 & 12,06 & 2,9 & $+0,6$ & 100 \\
\hline Kbz3 & 62,3 & 22,5 & 15,2 & 4,7 & 76,7 & 18,6 & 10,51 & 24,58 & 42,96 & 19,78 & 16,09 & 13,67 & 3,1 & $+0,6$ & 100 \\
\hline Kbz4 & 88,2 & 10,5 & 1,3 & 4,0 & 75,3 & 20,7 & 13,70 & 29,59 & 46,38 & 18,63 & 15,29 & 13,34 & 2,6 & $+0,7$ & 100 \\
\hline Kbz5 & 16,1 & 50,6 & 33,3 & 2,2 & 56,6 & 41,2 & 22,43 & 42,73 & 65,92 & 16,49 & 13,69 & 11,81 & 2,3 & $+0,5$ & 100 \\
\hline
\end{tabular}


Figure 16 - First diagram textures of 5 samples.

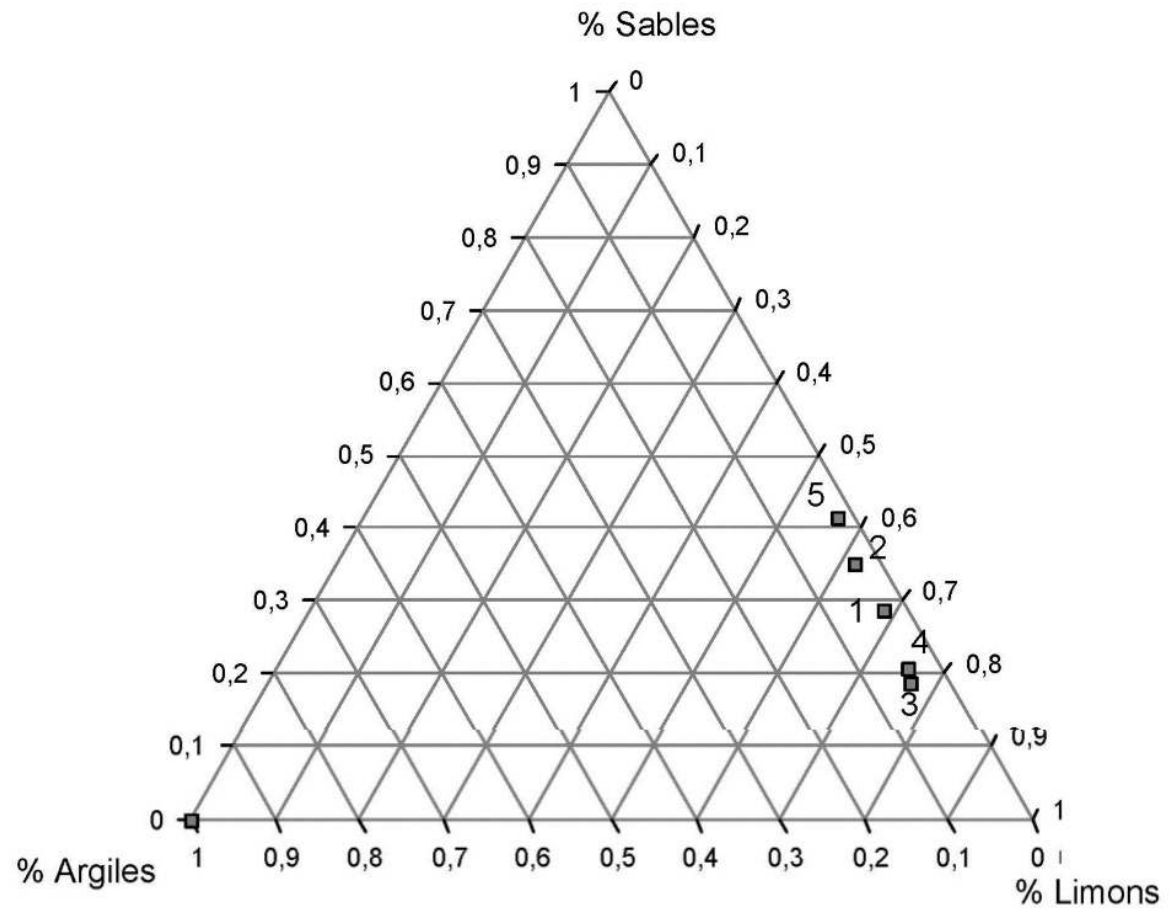

Figure 17 - Second diagram textures of 5 samples.

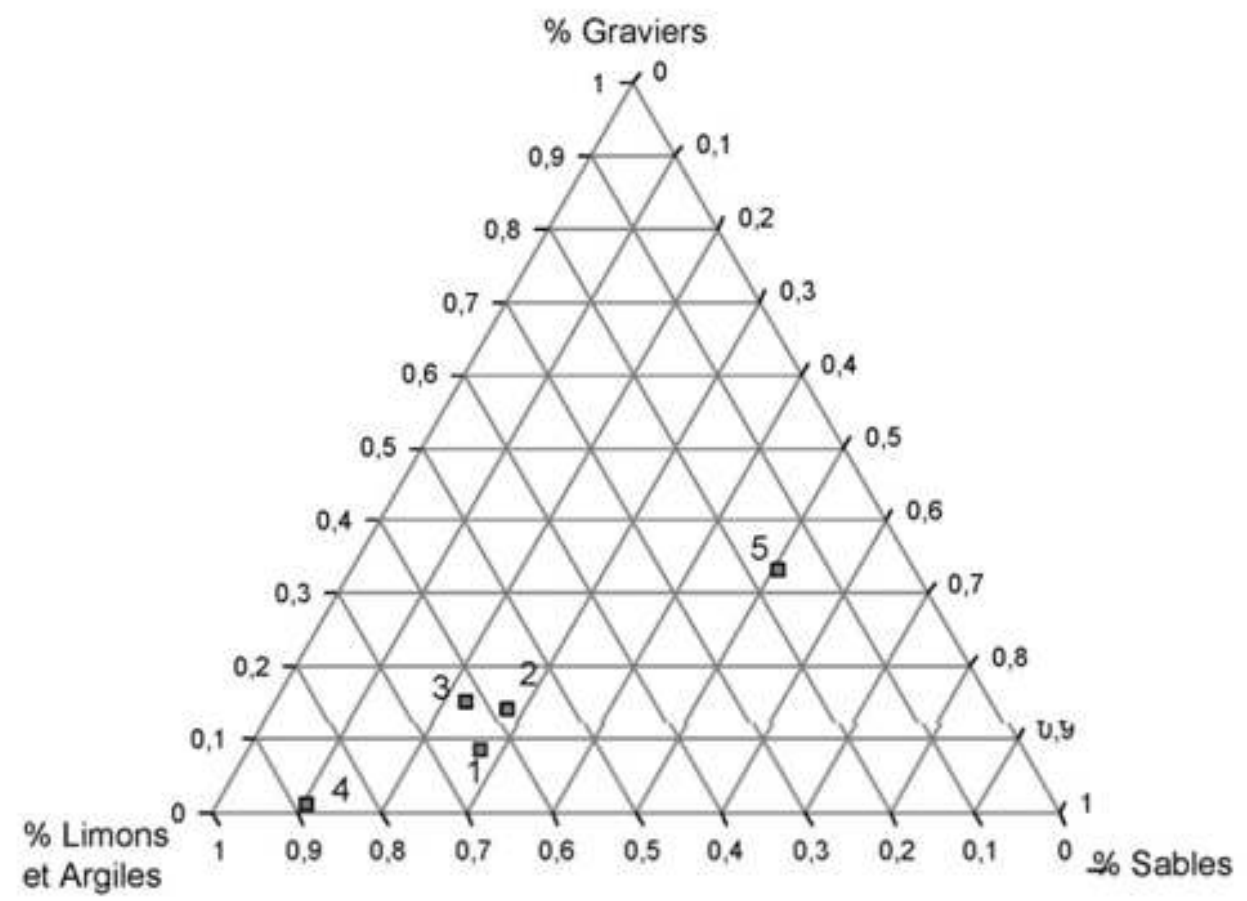


Figure 18 - ACP : variables = \%<50 microns, \%sand, \%gravel, \%clay, Q25, Q50, Q75.

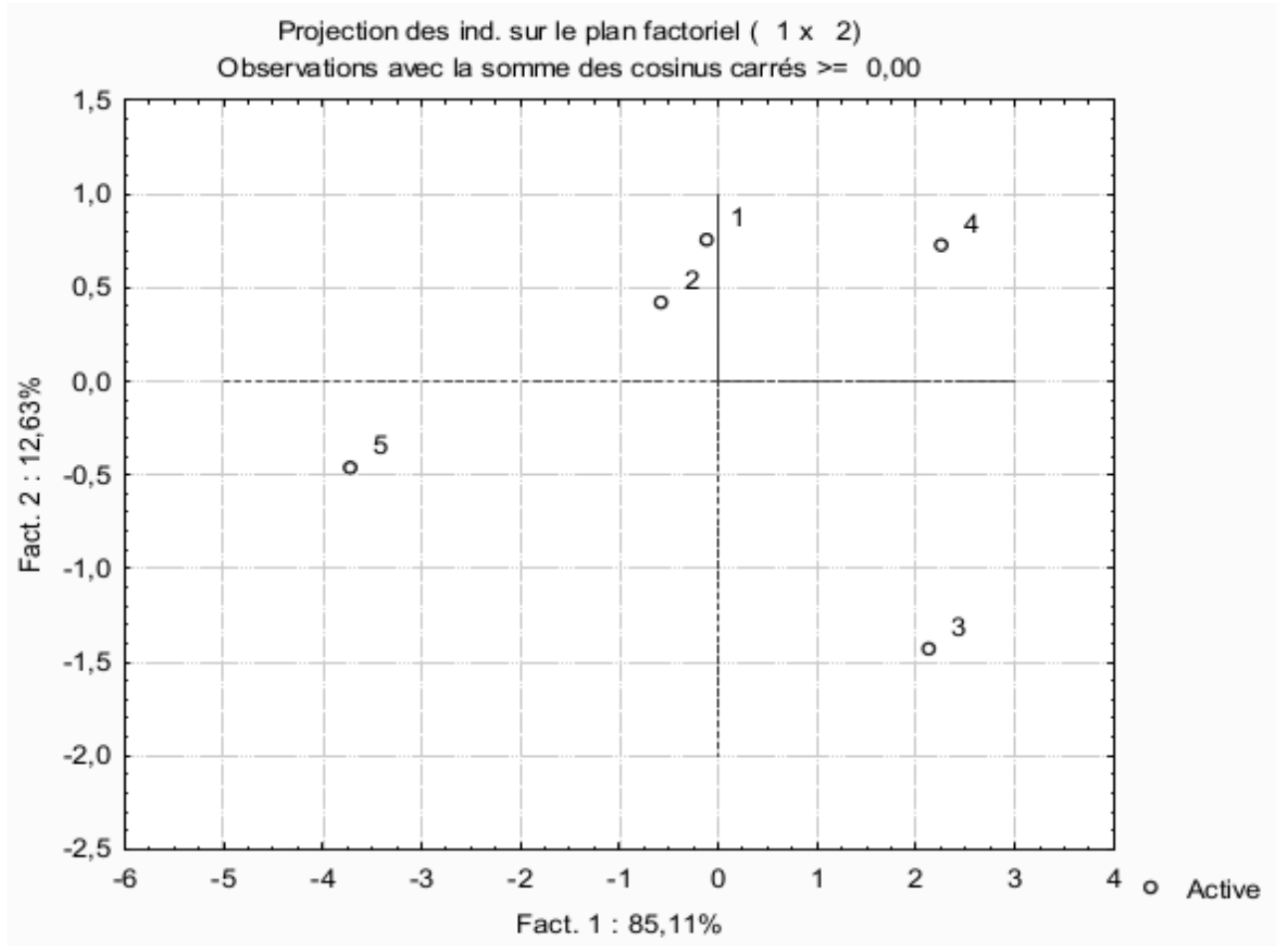

\section{5 - Spatial distribution of the archaeological objects}

The excavation was carried out by stratigraphic unit and by quarter of square meter. There was no regret in this choice of excavation, which allows a better connection between sieving and the recording of the objects manually, since the levels in place were not extended. The objects density was very different between areas (fig. 19 to 24). Among the Azilian squares in place, the angle of the shelter (J4-J5) undoubtedly holds the record for density, with 83 objects (including splinters) in J5. The destruction of the top of the bench at the back has probably removed many archaeological objects, but due to the slope of the ceiling, it was never a very comfortable area. Neither is it a preferential waste area as low densities can be observed in SU 4 and 5: 12 objects in M2, 8 in $\mathrm{M} 3,16$ in N2 and 26 in N3. Squares F4 and F5 show significantly higher concentrations, respectively 132 and 208, but they are accumulated occupations in a current soil, apparently without surface removal.

If these considerations are restricted only to the Azilian objects, the southern part of the shelter (also called the angle) still shows the highest concentrations: yet they were only peripheral areas to the settlement, moreover very humid in square $\mathrm{J} 5$, but which were along the natural circulation axis between the cave and the outside. It should be noted as a relevant factor in these distribution plans the grouping of the large used blades at the back of the shelter. The discovery of small shale plaquette in the Azilian levels has been stimulating information to determine the movements of the men and women from the late Palaeolithic. The three largest come from the same place as the blades, specifically in square $\mathrm{N} 2$; there is another over $50 \mathrm{~mm}$ long in $\mathrm{J} 5$. In contrast, the small fragments are distributed everywhere in the squares in place, which is difficult to interpret: splitting these objects is easy, but for these small items to be found 
everywhere, we must imagine that the shale objects were moved around in the settlement.

The distribution of the slag studied by N. Jouanet-Aldous can be described as completely opposite to that of the Azilian remains (which is reassuring ...), with an increase as one moves away from the cave towards the west and a presence in the squares F4 and F5 southwest of the main shelter. This dispersion is difficult to interpret, insofar as the corresponding medieval levels ( $7^{\text {th }}$ to $9^{\text {th }}$ century AD) were completely destroyed and scattered in front of the shelter. It is not clear, moreover, that these metal-related activities have avoided the rock-shelter and many slags were also found in the waste heap in front of block 4, waste coming from the infill of the cave.

\section{4 - Study of the stone tools}

\section{1 - General aspects of the lithic assemblage}

The knapped lithic industry collected during the excavation in July 2011 totals 1,313 objects, half of which comes from inside the shelter at the level of the bench, 20\% from the southern part of the shelter, the remainder being collected in the disturbed areas of the shelter (strips 4 to 9) or in the interstices (fig. 25). Part of these objects comes from the upper SU $(22 \%$ - SU $1,7,30)$ or from the wall effects (13\% - SU 13 and 32); another part from the multiple disturbed units (24\%). The remaining $20 \%$ comes from the stratigraphic units in place in the shelter, to which can be added the SU 31 in strip F (southern part), which account by itself for $21 \%$ of the lithic objects in place, with strong reservations here as they laid in the current soil.

This is a lithic series affected by thermal shocking in a normal quantity for a regional site $(23 \%)$ and the rate decreases significantly if one considers only the Azilian SU in place (14.5\%). Flint is the dominant material (72\%), followed by microquartzite from La Forest-Landerneau (8\%), Clos chalcedony (7\%) and ultramylonite from Mikaël (5\%). Eocene sandstones are rarer (3\%) as well as phtanites (1\%) (fig. 26). These proportions differ significantly from the inventory by J.-M. Moullec: in the series he had collected by sieving the waste soil, flint only made $65 \%$ of the objects, the regional rocks being the same as in our series but in larger amounts. It can be easily explained by the fact that the 2011 excavations have affected preferentially the final Palaeolithic levels in which flint dominates more (fig. 27), while the previous collecting took better account of the regionally known Mesolithic for the great use made in it of rocks from the Armorican platform (Marchand 2012). Moreover, in the Pont-Glas shelter with exclusively Mesolithic occupations, these materials accounted for half of the industries. It is obvious that regional rocks are less adapted to laminar knapping (Marchand and Tsobgou Ahoupe 2007) and therefore that they have been more neglected in the Azilian.

In general, our observations using a binocular microscope supplemented by J. Jacquier's observations (University of Rennes 1) reveal a poor conservation of the traces of use, except for the impact marks on the projectiles insets or the most obvious scarring of the edges. 
Figure 19 - Location of the knapped lithic remains from all the stratigraphic origins (CAD: G. Marchand).

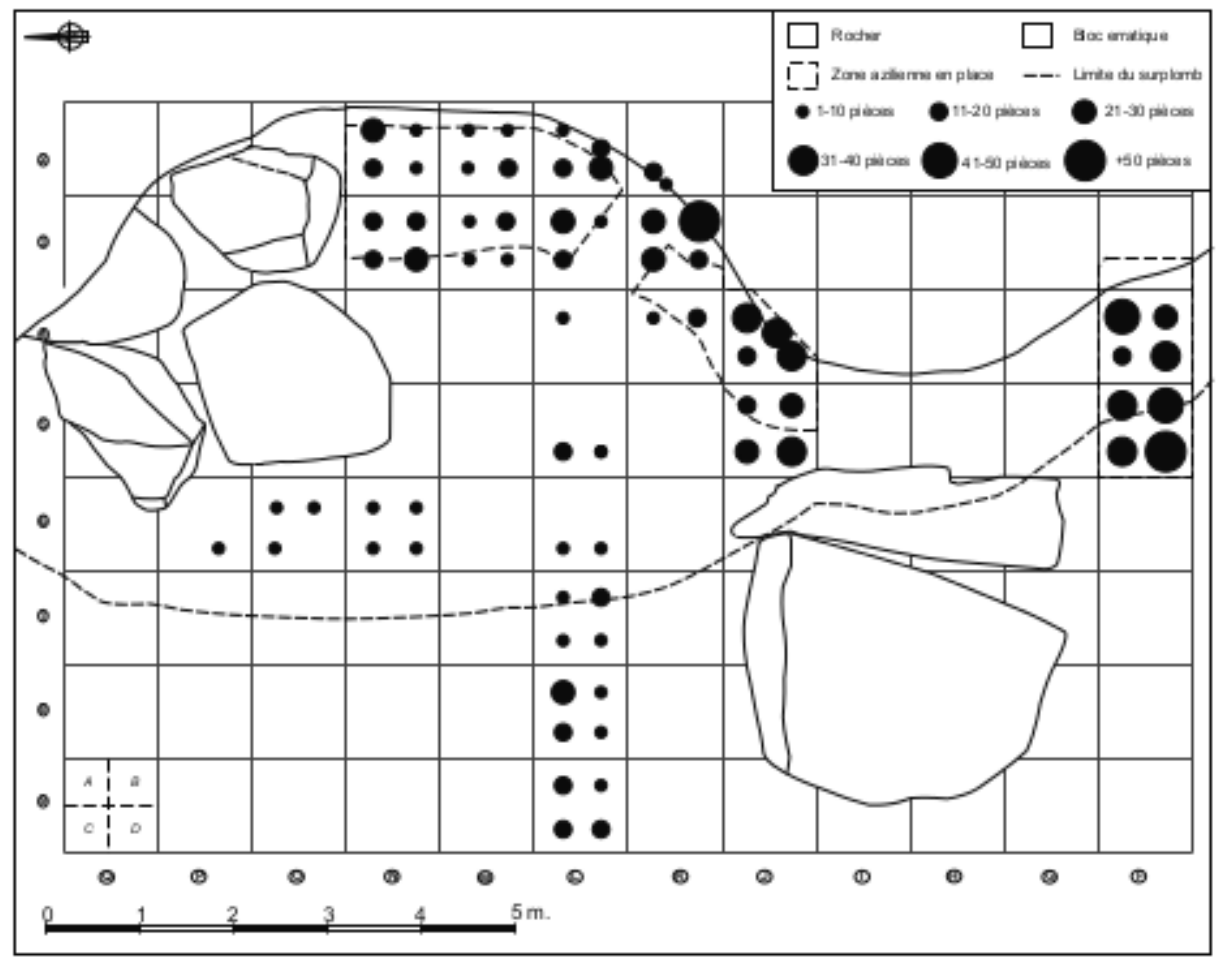

Figure 20 - Location of the knapped lithic remains in the Azilian levels of the rock shelter (CAD: G. Marchand).

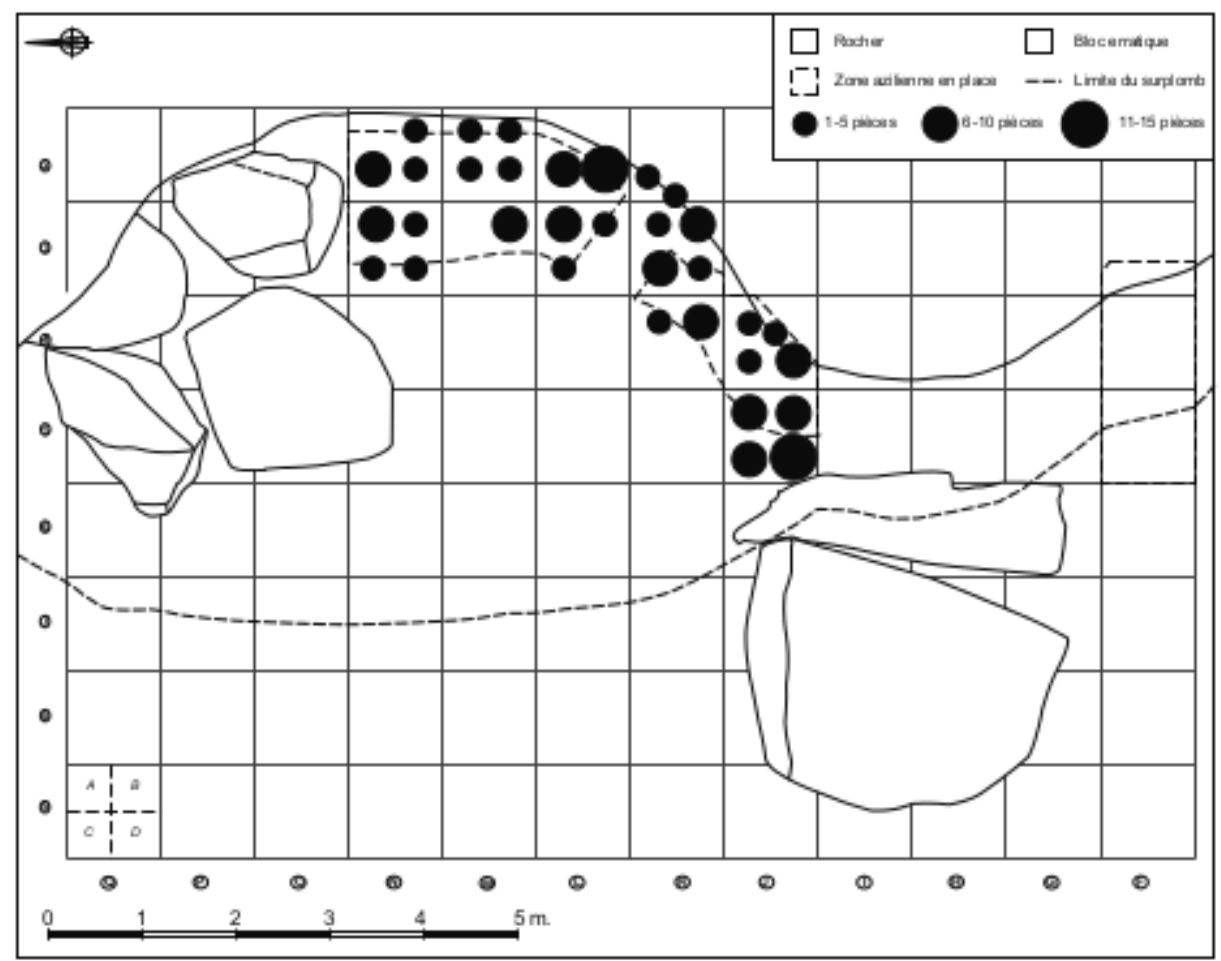


Figure 21 - Location of the Azilian points from all the stratigraphic units (CAD: G. Marchand).

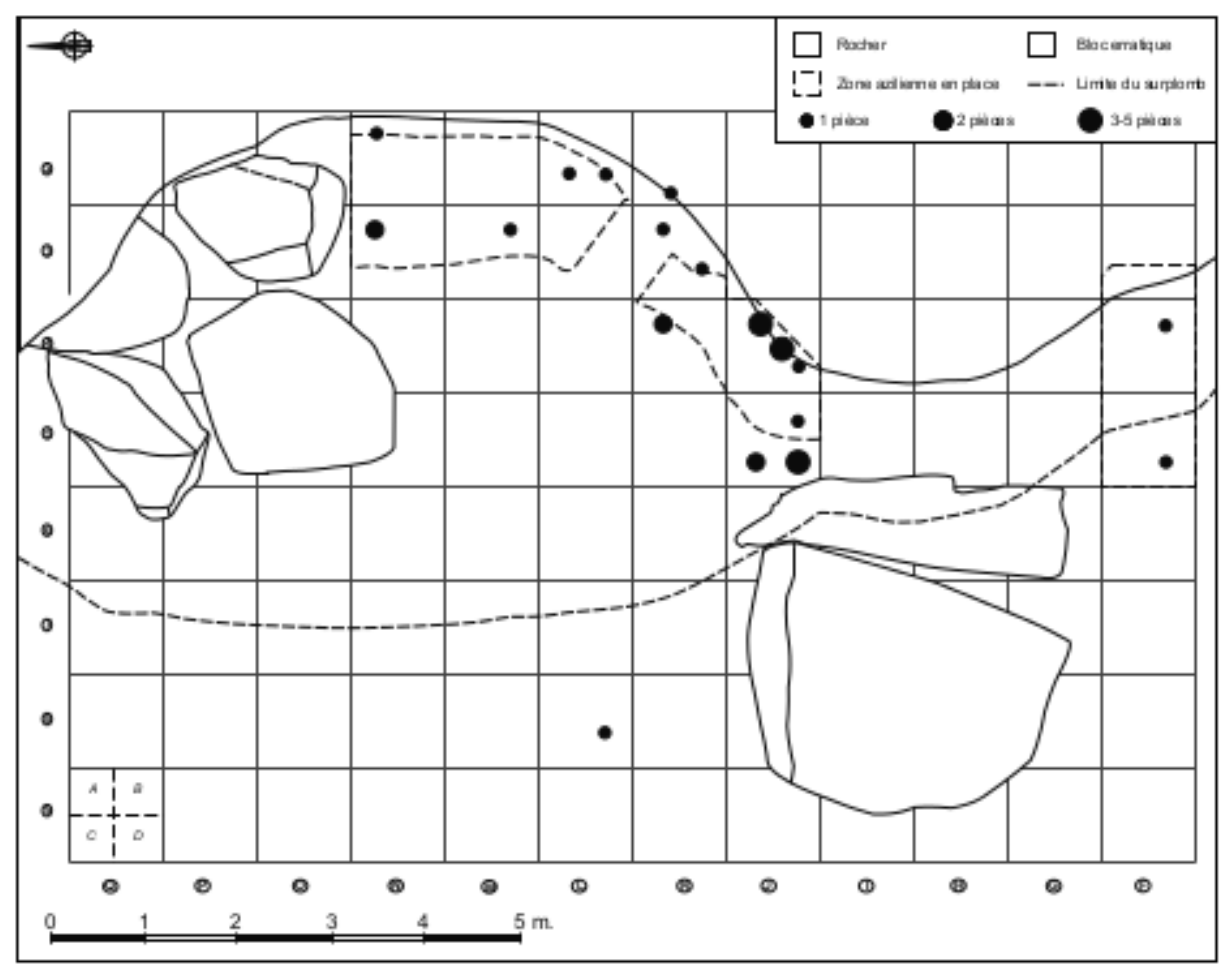

Figure 22 - Location of the retouched tools and the used blades from all the stratigraphic units (CAD: G. Marchand).

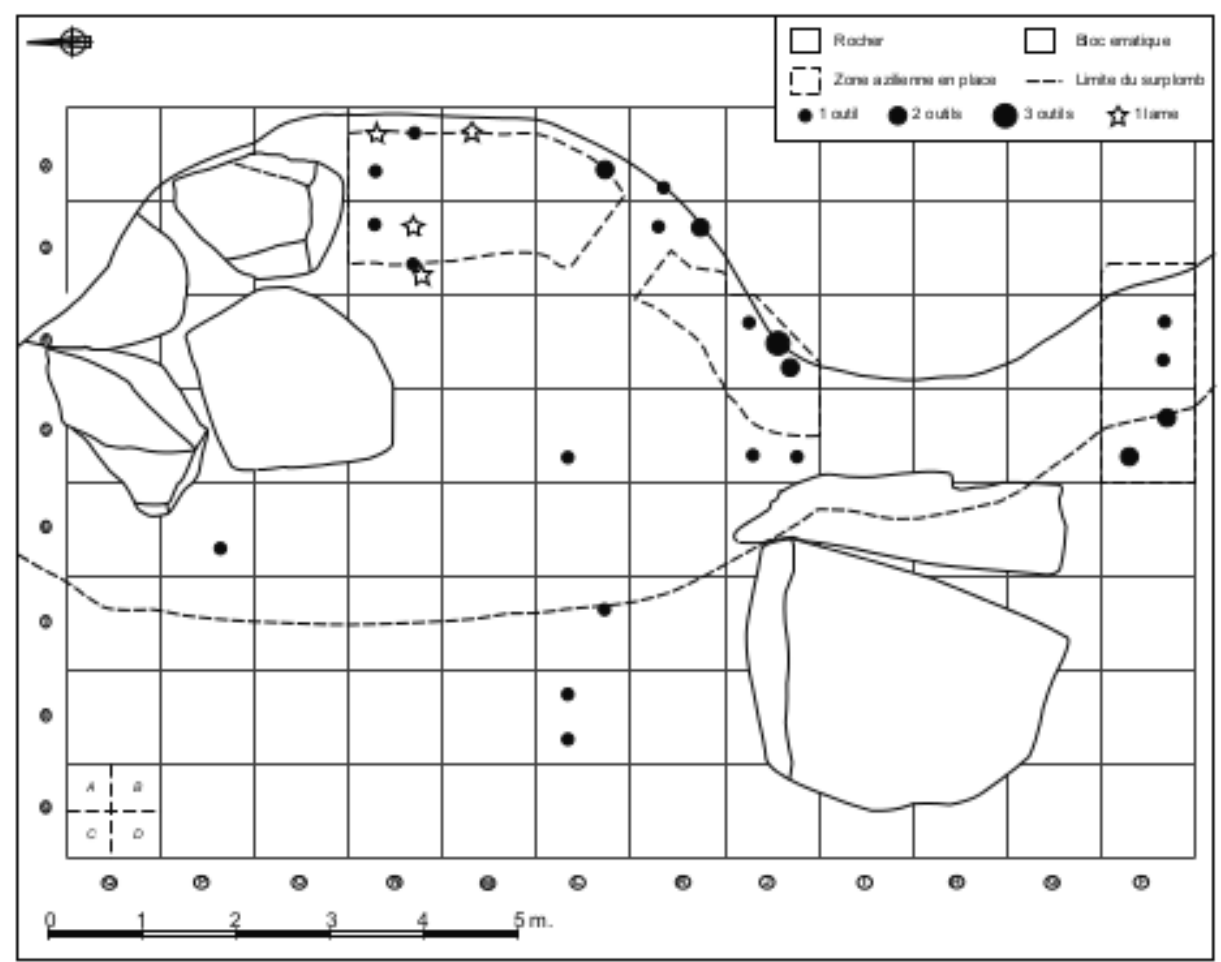


Figure 23 - Location by square meters of the schist plates bigger than $10 \mathrm{~mm}$ in the Azilian levels (stratigraphic units: 4, 5, 6, 8 et 11) (CAD: G. Marchand).

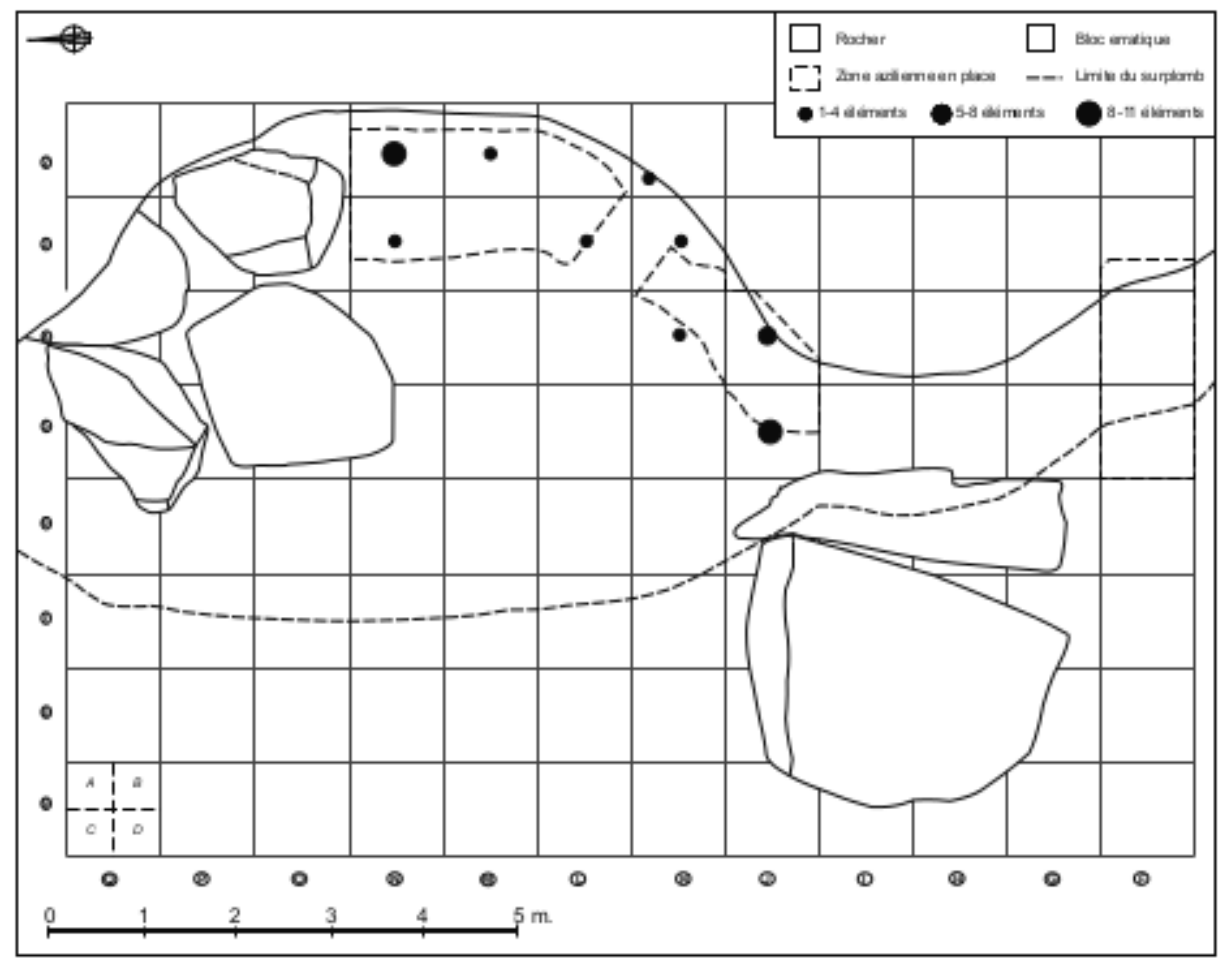

Figure 24 - Location of the burin spalls from all the stratigraphic units (CAD: G. Marchand).

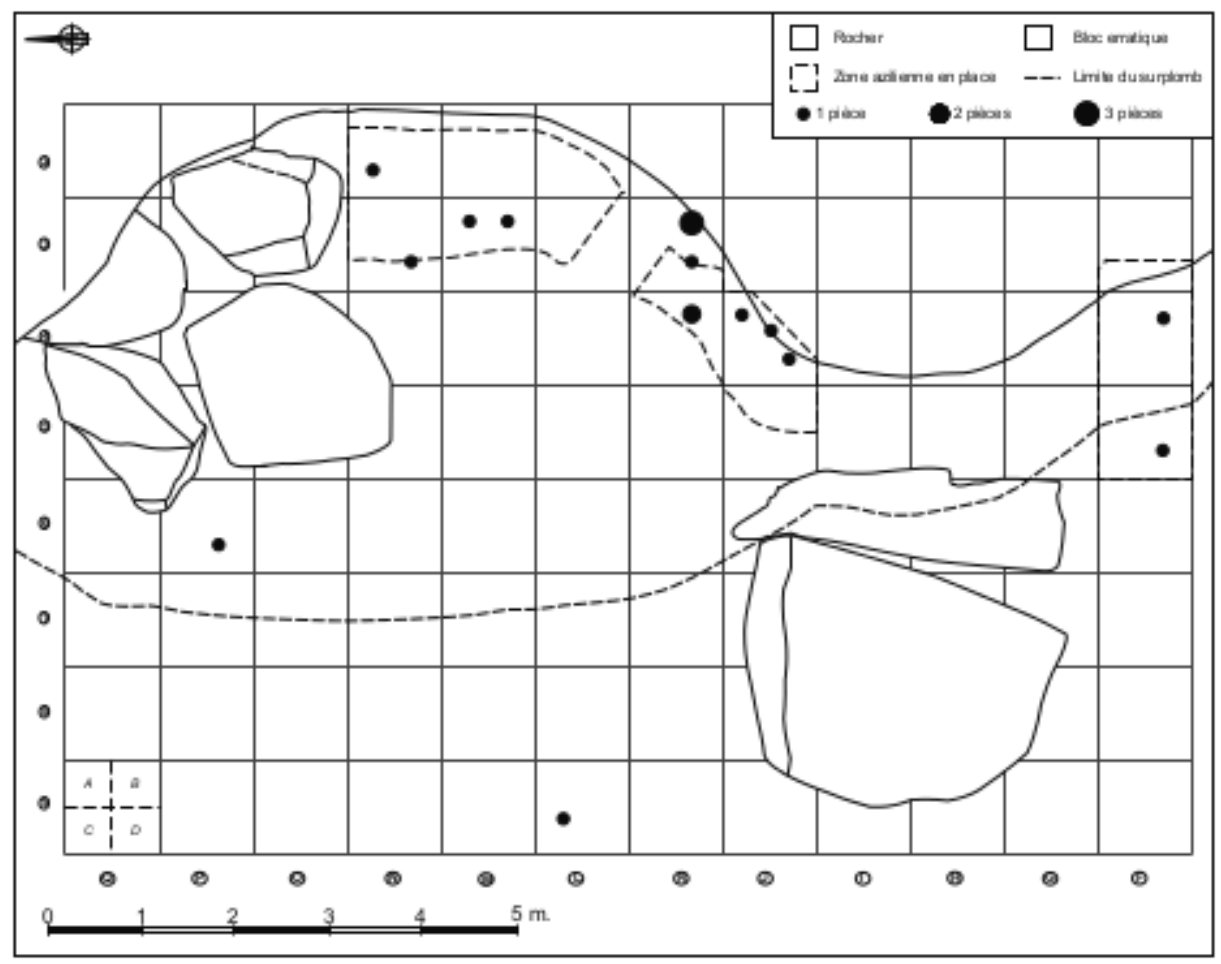


Figure 25 - Origins of the 1313 lithic pieces found in the rock shelter during the 2011 excavation.

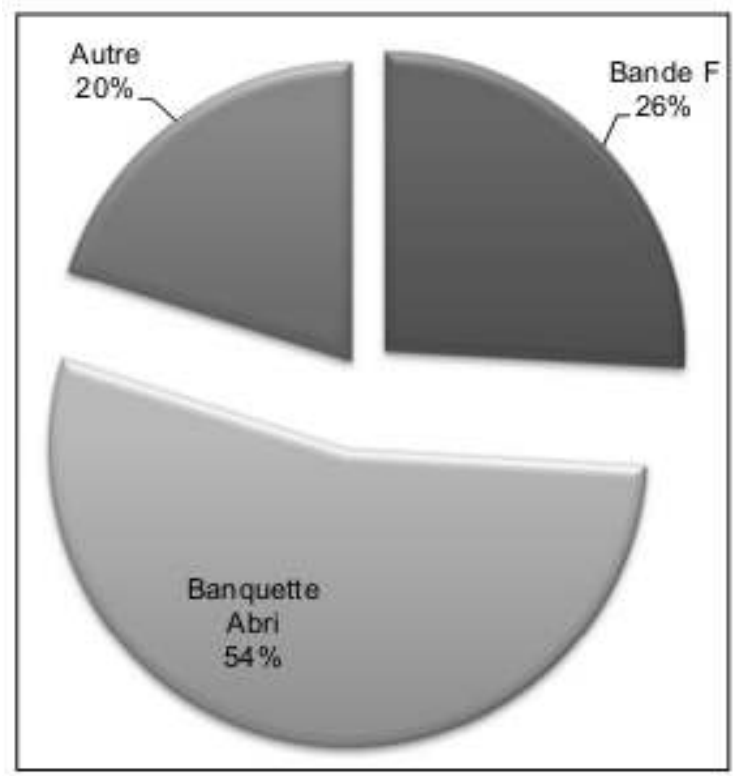

Figure 26 - Main raw materials of all the assemblages $(N=1313)$ and in the azilian level $(N=314)$.

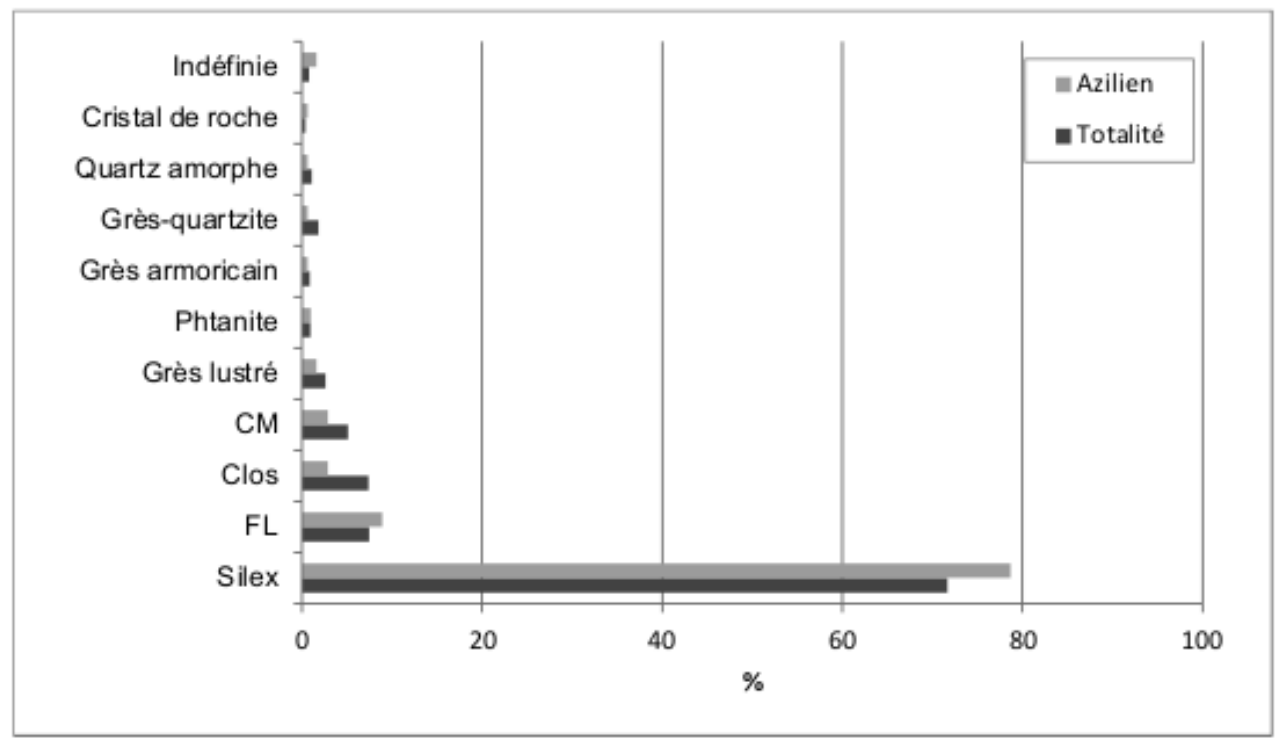

\section{2 - Material from the Azilian stratigraphic units}

\subsection{1 - General characteristics}

The knapped stone industry collected in the homogeneous stratigraphic units within the shelter (SU 4, 5, 6, 8 and 11) consists in 314 items, including 21 projectile insets, 9 retouched tools, 19 a posteriori tools and 137 splinters. They are little affected by fire: all raw materials considered, there is $13.4 \%$ burned or heated objects and only $7.5 \%$ just for flint. The series is also little patinated, since $6.1 \%$ of the flint is concerned and $2.4 \%$ of objects show a simple coating (this information is of little interest to other rocks whose surface alteration is less noticeable). These lithic artefacts have not suffered 
from specific alteration and their breakage pattern is "normal," with even blades of large dimensions by regional standards.

\subsection{2 - Raw materials in the Azilian} early as the early Azilian in the centre of the Finistere area, which has obvious implications for our conceptions of the degree of mobility of human beings at the time (fig. 26). These technical systems, although laminar in essence, have included a small portion of rocks little favourable to these productions, it is true for the manufacture of flakes.

Flint accounts for $79 \%$ of the collected artefacts, with several varieties (tabl. 4, 5 and 6) Laminar production is best expressed on these rocks. The position of this rock-shelter far from all potential sources of supplies is probably the origin of the low number of observable cortex and hence our difficulty in defining whether or not the flints were imported. Gray (medium gray) and gray-yellow varieties make $60 \%$ of these rock types in the Azilian, as they undoubtedly dominate in the mixed-up series of the shelter regardless periods (fig. 27). Their cortexes are certainly worn and indicate collecting on the beaches of the Palaeo-Channel. The yellow flint that makes $25 \%$ of the corpus is also from marine pebbles for most. The current beaches where such pebbles can be found are now located $37 \mathrm{~km}$ to the north, but with sea level at least $60 \mathrm{~m}$ lower, one would need to go at least 10 kilometres off the present-day coast to reach the barrier beaches. The Cretaceous deposits of the English Channel are even further and they were not directly accessible in the Late Glacial (Monnier 1980). Among the original flint, relatively rare, there is a black variety, dry in appearance and with a matt surface, which arrived in the form of fairly large blocks (worn or not?) and was used to produce flakes. Within these ten items collected in the levels in place, there is a large rejuvenation core flake indicating a bladelet debitage in a semi-turning rhythm, with a thin abrasion of the overhang. A translucent yellow flint shows long white filaments sometimes grouped in bundles identified as sponge spicules; also the presence of bryozoans suggests a marine formation. It has a non-worn cortex, thin and without subcortical area, which indicates collecting in a sedimentary basin, yet to be detected. The nearest flint clay deposits of secondary age are more than $280 \mathrm{~km}$ away in a straight line from the east, in the Sarthe region. This very characteristic rock for the Azilian levels was used in the shape of blades and flakes.

Microquartzite from La Forest-Landerneau (from now on called FL) is a rock with sugary aspect, consisting of quartz grains of apparently identical dimensions without detectable cement. Found in large banks in the eponymous municipality, east of Brest in the Elorn valley, $40 \mathrm{~km}$ west of the site, it would also exist sporadically throughout the Northern Finistère fault (north Armorican shear or NAS; Gouletquer et al. 1996; Marchand and Tsobgou Ahoupe 2007) at distances of about twenty kilometres from Kerbizien. An examination with binocular microscope was necessary to distinguish some flint and the gray and black varieties of $\mathrm{FL}$, as the latter is a fine-grained rock. Note that the gray variety is zoned, with alternately light gray and dark gray strips, 1 to $2 \mathrm{~mm}$ thick. Among the 28 fragments collected (8\%), we can identify three bladelets obtained with a stone hammer, from 9 to $10 \mathrm{~mm}$ wide, one of which is a blank for an unidentified projectile inset and eight small flakes, the remainder being splinters.

PALEO, 25 | 2014 
from the NAS faults south of Morlaix, like the FL microquartzite, cataclasite from Mikael and Clos chalcedony are also present, with respectively 1.6 and $2.9 \%$ of the objects. Unfortunately these small numbers are preventing us from catching the subtlety of the chaînes opératoires. For the first one, there are two splinters, two flake fragments and a blade proximal, that one imagines short because this rock is hardly conducive to such productions. For Clos chalcedony, the results are the same. This is a multicoloured rock (white yellow, red, pink), also translucent with small inclusions and often a thin bedding. Large thick plates of about $50 \mathrm{~mm}$ are known with lengths up to $120 \mathrm{~mm}$ in the disturbed areas of Kerbizien, as well as in J.-J. Mazurier's collection. It seems very sensitive to heat, especially as the internal cracks are very visible because the rock is transparent. The three small irregular flakes and the two bladelet fragments, all obtained with a stone hammer, say little of the related production. A large site-quarry is known $17 \mathrm{~km}$ to the north, at Clos (Plourin-les-Morlaix), beyond the Arrée Mounts; it also yielded on the surface curved backed points in flint, in chalcedony or FL microquartzite, mixed with projectile points of the Early Mesolithic (Gouletquer et al. 1994).

The finding of a production in the Azilian is much more certain for the Eocene sandstone, as among the nine elements $(2.9 \%)$, there is a curved backed monopoint on bladelet (fig. 28, No. 13). There is also a two-sided proximal bladelet fragment, with a smooth and wide butt, whose overhang underwent intense abrasion, resulting in a certain blunting like on some flint blades. Rock crystal has been knapped in flakes in an anecdotal manner at the scale of the site (five objects out of 1,313); only one splinter and a very small distal fragment of bladelet might suggest knapping in the Late Glacial.

The Azilian lithic assemblage collected in Kerbizien shows exchanges or movements on distances of about fifty kilometres to the north to the shores of the Channel; Jurassic or Cretaceous levels in the eastern Armorican Massif make another pole of supplying, which invites us to imagine much longer travels. Technological analysis may teach us more about their working modes. 
Figure 27 - Main raw materials in the azilian level $(\mathrm{N}=314)$.

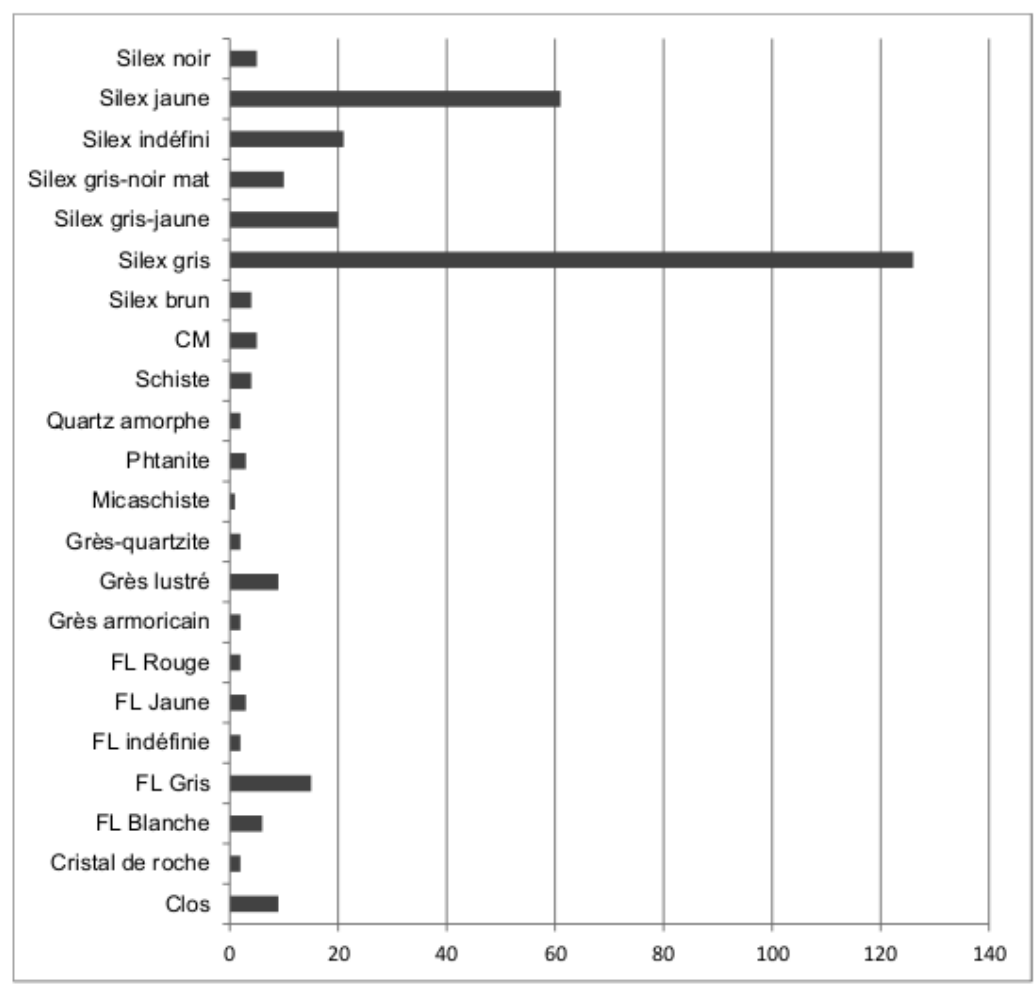

Table 4 - Classification of the unretouched blanks by raw material. Pieces found exclusively in the homogeneous azilian levels (US 4, 5, 6, 8 et 11 ).

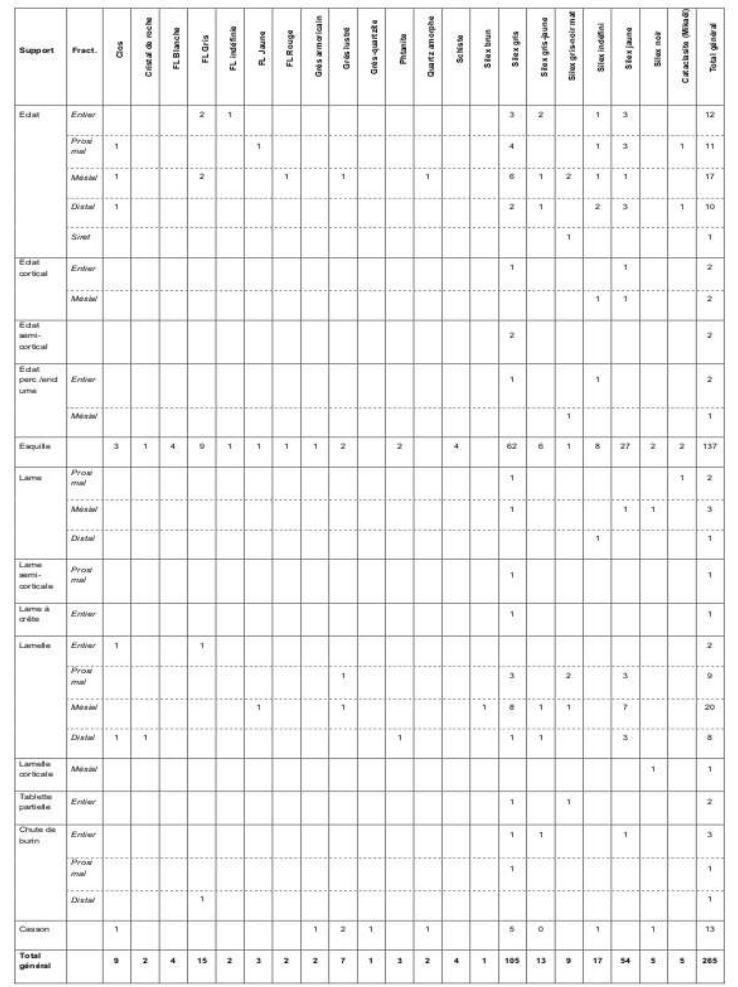


Table 5 - Arrowheads from the homogeneous azilian levels (US 4, 5, 6, 8 et 11).

\begin{tabular}{|c|c|c|c|c|c|c|c|c|c|}
\hline Type & Fraction & 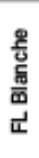 & $\begin{array}{l}\frac{\mathscr{g}}{\text { 总 }} \\
\text { 总 }\end{array}$ & $\begin{array}{l}\text { 들 } \\
\text { ख } \\
\text { क् }\end{array}$ & $\begin{array}{l}\text { 은 } \\
\text { × } \\
\text { 心 }\end{array}$ & 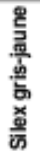 & $\begin{array}{l}\text { 름 } \\
\text { 흘 } \\
\text { 즣 }\end{array}$ & 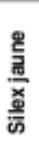 & 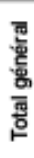 \\
\hline \multirow[t]{2}{*}{ Armature indéfinie } & Fragment & 1 & & & 1 & & 2 & 1 & 4 \\
\hline & Krukawsikl & & & & 1 & & & & 1 \\
\hline Bipointe azilienne & Enter & & & & 1 & 1 & & & 2 \\
\hline \multirow[t]{2}{*}{ Monopointe azilienne } & Entler & & & & & 1 & & & 1 \\
\hline & Fragment & & 1 & & 1 & & & & 2 \\
\hline Plèce à dos courbe & Fragment & & & 1 & 5 & & & 1 & 7 \\
\hline $\begin{array}{l}\text { Pléce à dos } \\
\text { rectiligne }\end{array}$ & Fragment & & & & 3 & & & & 3 \\
\hline Total géneral & & 1 & 1 & 1 & 12 & 2 & 2 & 2 & 21 \\
\hline
\end{tabular}

Table 6 - Tool types found in the homogeneous azilian levels (US 4, 5, 6, 8 et 11).

\begin{tabular}{|c|c|c|c|c|c|c|c|c|c|c|c|}
\hline Support & Type d'outil & 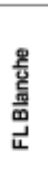 & $\begin{array}{l}\text { 恕 } \\
\text { 总 } \\
\text { 岁 }\end{array}$ & 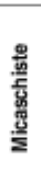 & 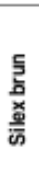 & 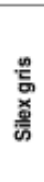 & 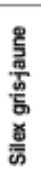 & 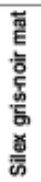 & 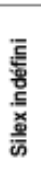 & 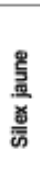 & 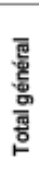 \\
\hline \multirow[t]{5}{*}{ Eclat } & $\begin{array}{l}\text { Bord abattu total } \\
\text { rectiligne }\end{array}$ & & & & & & & & & 1 & 1 \\
\hline & Retouche diverse & & & & & & & 1 & & & 1 \\
\hline & Fil ébréché continu & & & & 1 & & & & & 2 & 3 \\
\hline & Fil ébréché discontinu & 1 & 1 & & & 1 & 1 & & & 1 & 5 \\
\hline & Pièce esquillée & & & & & & & & 1 & & 1 \\
\hline Galet & Galet fendu et abrasé & & & 1 & & & & & & & 1 \\
\hline \multirow[t]{2}{*}{ Indéfíni } & Retouche diverse & & & & & 1 & & & & & 1 \\
\hline & Piéce esquillée & & & & & & & & 1 & & 1 \\
\hline \multirow[t]{3}{*}{ Lame } & Retouche diverse & & & & & 2 & 2 & & & & 4 \\
\hline & Fil ébréché continu & & & & & & 1 & & & 1 & 2 \\
\hline & Retouches partiel les & & & & & 1 & & & & & 1 \\
\hline Lame à crête & Burin & & & & & 1 & & & & & 1 \\
\hline \multirow[t]{4}{*}{ Lamelle } & Coche & & & & & 1 & & & & & 1 \\
\hline & Fil ébréché discontinu & & & & 1 & 2 & & & & & 3 \\
\hline & Fil ébréché continu & & & & & & & & & 1 & \\
\hline & Retouches continues & & & & & 1 & & & & & 1 \\
\hline $\begin{array}{l}\text { Total } \\
\text { général }\end{array}$ & & 1 & 1 & 1 & 2 & 10 & 4 & 1 & 2 & 6 & 28 \\
\hline
\end{tabular}

\subsection{3 - Incomplete chaînes opératoires}

Detectable operating sequences on the rocks from the Armorican Massif have been briefly mentioned above; they concern a flake production, 15 to $30 \mathrm{~mm}$ long, little standardized and made with hard hammer (tabl. 7). The butts are mostly punctiform and show little abrasion.

The most relevant technical information rather comes from the 247 flint pieces collected in place. The lamino-laminar products are in high proportions with $22.6 \%$ of the total of the raw and retouched objects, all rocks considered or $24.3 \%$ only for the flint. If these considerations are refined by taking into account only the whole pieces 
and the proximal fragments in flint, blades and bladelets then reach $38 \%$. There is clearly a wide variety of production standards, from bladelet to the broad blade, from widths of $5 \mathrm{~mm}$ up to those of 24 , even among the projectile insets. Moreover, the average widths of the latter are $9.8 \mathrm{~mm}$ with a standard deviation of 3.4 and a simple glance at the drawing board (fig. 28) is enough to be aware of this module disparity. Thus at the two extremes, a small monopoint from square K4B (SU 4) and a bipoint from square J5D (SU 8), can be juxtaposed with many intermediate cases. However, one should be cautious about the presence in K3D (SU 5) of a very narrow backed projectile inset fragment $(3.8 \mathrm{~mm})$, perhaps intrusive from the Mesolithic levels where these objects are better known. Differences in longitudinal profile are also quite striking, the blanks of some points being frankly convex, though the most common are straight. The wide and flat blades are intended to be used for their cutting edge, sometimes with a resharpening or reinforcement by lines of continuous semi-abrupt direct retouches (fig. 29). Finally, the five burin spalls, from 15 to $25 \mathrm{~mm}$ long, alert us indirectly about a third goal of the blade production, making elongated and thick blanks for burins (but are they always blades or large flakes?).

The blade production seems largely unipolar, but this statement must be adjusted because the bipolar exploitation of the same tablet does not necessarily lead to a very large covering by the different sequences, especially when they cross distally and the splitting of the objects makes the observation difficult. A large fragment of blade mesial indicates such a mode; this piece also shows a removal prior to the bipolar debitage, maybe related to a lateral crest on the core. It was retouched on both sides, then struck - more than retouched - in a transverse movement that created stepped low angled inverse retouches (fig. 29, No. 4). To finish this description, a tongue fracture of the blade after retouching should be noted. We can also mention a distal blade fragment probably inserted into a regular laminar debitage, showing opposite negatives (fig. 29, no. 5 - M3D), unfortunately from a mixed level (SU 7).

Blades longer than $80 \mathrm{~mm}$ and 20 to $25 \mathrm{~mm}$ wide are one of the most important debitage objectives, especially as some were preserved whole in the form of knives with much altered or chipped edges (fig. 30 and 31). The longitudinal curvature of these flat blades is quite pronounced. Some (e.g. N3D SU 5, fig. 29, No. 1) show a progressive widening from their proximal part. Half of the observable objects $(\mathrm{N}=16)$ show a much pronounced grinding of the overhangs associated with punctiform butts or in two cases widely dihedral (this is also the case for the Eocene sandstone). The percussion scars have little to say. Direct percussion with a soft stone hammer is not the preferred hypothesis from the available scars, since no slight ripples (or wave) can be observed on the lower face. Direct soft percussion may be present on some blades with wide and blunted butts; hard direct percussion is however very likely on other blade butts, and on some flakes.

51 Flake debitage shows a very low standardization and the scarcity of retouched tools even prevents defining clear objectives for production. Out of the 23 butts of diagnostic non-cortical flakes, 21 show the scars of direct hard percussion, with a preliminary preparation of the overhangs similar to the blades. This brief inventory reflects the incomplete nature of the chaînes opératoires, where the start such as shaping the volumes (probably by crests) is missing, as well as the cores. The splitting up of the sequences in space is obvious, but at what level? On the entire site or only in the 
remaining part we were able to excavate? Impossible to answer. But the more precise study of the tool kit and its traces of alteration will allow us to refine our conclusions.

Figure 28 - Curved-backed points discovered in the azilian levels inside the rock shelter (drawings: G. Marchand).
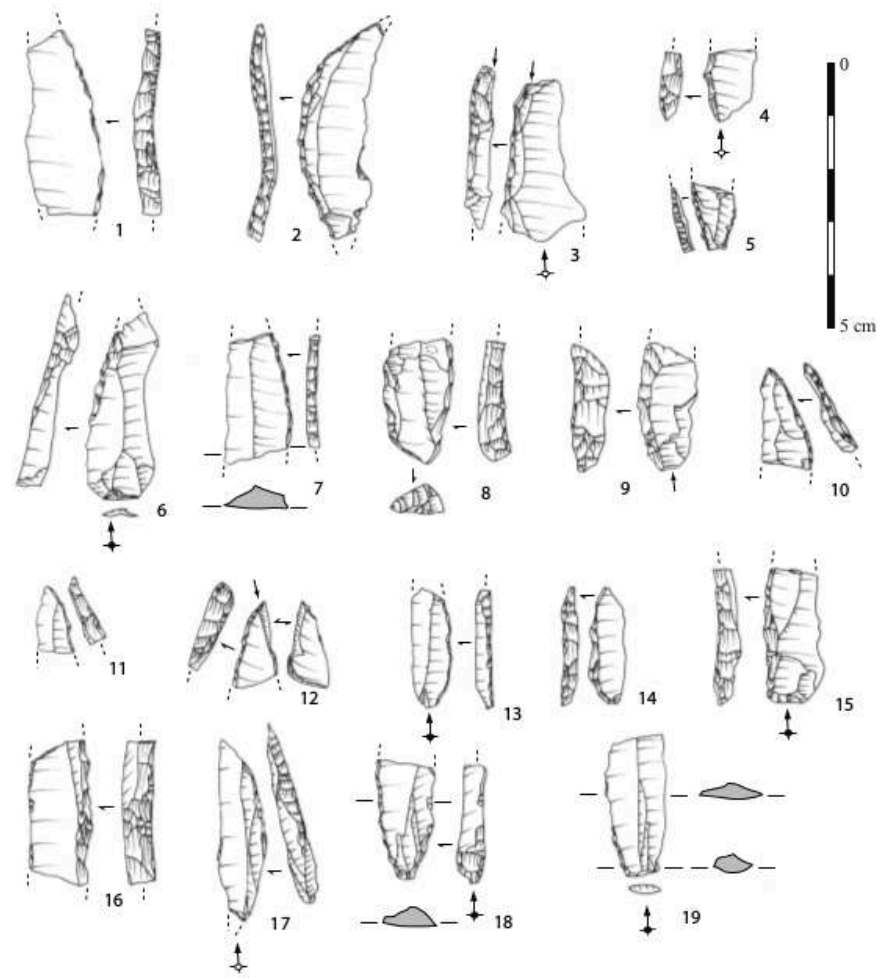

Table 7 - Size of all the lithic remains, of the unretouched flakes and of the uncortical blades and bladelets (all kind of raw materials). Pieces found exclusively in the homogeneous azilian levels (US $4,5,6,8$ et 11 ).

\begin{tabular}{|c|c|c|c|c|c|c|c|c|c|}
\hline & \multicolumn{3}{|c|}{ Totalité (N=314) } & \multicolumn{2}{c|}{ Éclat a-cortical et semi-cartical brut (N=62) } & \multicolumn{2}{c|}{ Lames et lamelles brutes $(\mathrm{N}=52)$} \\
\cline { 2 - 11 } & Longueur & Largeur & Épaisseur & Longueur & Largeur & Épaisseur & Longueur & Largeur & Épaisseur \\
\hline Moyenne & 23,6 & 12,1 & 3,5 & 17,4 & 14,5 & 3,8 & - & 9,6 & 2,5 \\
\hline $\begin{array}{c}\text { Écart- } \\
\text { type }\end{array}$ & 15,8 & 5,7 & 2,0 & 7,3 & 4,5 & 2,2 & - & 3,4 & 1,0 \\
\hline Maximum & 83,6 & 46,7 & 15,1 & 35,0 & 26,1 & 12,4 & - & 24,0 & 5,0 \\
\hline Minimum & 8,2 & 2,4 & 0,8 & 8,2 & 7,4 & 1,1 & - & 3,4 & 0,8 \\
\hline
\end{tabular}

\subsection{4 - A very special functional spectrum}

The utilization rate by blank is more important for the blades (66.7\%) than for the bladelets $(24.0 \%)$ or the non-cortical flakes (17.7\%). The small number of other blanks makes statistical considerations little interesting (tabl. 5 and 6). The retouched tool kit is in direct continuity with the blanks used without prior retouching (also called a posteriori tools), as they are in four cases blades with retouched edges and in two cases blanks with some retouches. The oblique angle of the retouches and their regularity indicate resharpening during use. There is also a fragment of straight backed edge flake, $12.3 \mathrm{~mm}$ wide, too short to bear any interpretation or a proximal bladelet fragment with a notch obtained by bending. Except for a burnt pièce esquillée, blanks 
with simply used cutting edges dominate, flakes or blades. A large fragment of blade shows semi-abrupt direct retouches, continuous on both edges, with a later use in thrown percussion on one edge, resulting in inverse scarring (N3A).

To this first part of the tool kit, associated with cutting actions for most, we must add a second one made of the projectile insets (fig. 28). Several modules of laminar blanks are found for curved backed points, which can only be estimated because they are obviously well modified by retouching. They are fairly regular blades and bladelets with straight profile for most, or surprisingly arched for some large objects (J5B -SU11 or J5D-SU8), or even twisted (N3A-SU5). If we consider the 21 whole or fragmented insets with curved back collected in the Azilian levels in place in 2011, the widths are between 6.2 and $15.4 \mathrm{~mm}$, with an average of $10.3 \mathrm{~mm}$ (standard deviation: 3.0). The blanks have an average thickness of $3.3 \mathrm{~mm}$ (standard deviation: 1.2). The whole pieces also show a clear disparity in the lengths: 22,34 and $41.2 \mathrm{~mm}$ for the levels in place and a $46 \mathrm{~mm}$ long piece of in SU 31. Before interpreting this as a functional diversity we must surely take into account the duration of the Azilian of almost a millennium and therefore the multiple imaginable incursions on this site, the goals of the debitage and the raw materials availability that change each time in a subtle way.

Out of the 15 Azilian projectile insets for which this type of analysis is possible (monopoints, bipoints or curved backed pieces, curved or straight backed pieces), the lateralisation balances out left and right. Retouches are in general abrupt and direct, in one case crossed abrupt when the retouch line crosses an arris on a thick blank (6 mm K2D-SU5 - fig. 28, $n^{\circ} 16$ ). In the levels in place, two bipoints and three monopoints can be noted. A fragment among the thickest also shows a convex base with direct retouch (J4A-SU1G- fig. 28, No. 8); other bases correspond to still untreated butts, the apical end being generally in the distal part.

Many retouching splinters found in the levels at the back of the shelter demonstrate the manufacture of large tools a few millimetres thick, some of which are probably Azilian points. This activity would also be indicated by three objects with curved back with a fracture of the Krukowski type, that is to say a breakage during the retouching of a back (J4D-SU8 and N3A-SU5). Yet the worn aspect of these points also indicate "coming back from hunting": there are two fragments of projectile insets with pseudo burin-like impacts of longitudinal axis (point use), while the number of neat breaks could also testify of such impacts. Apical extremities are rare and by putting together the breakages during manufacturing, the retouches and the breakages on impact, the assumption of a weapon repair during the various steps of fitting/taking off the handle gains credibility.

The third area of activity is represented by the burins, but mostly indirectly. Indeed, only one such tool has been identified, while five burin spalls were collected in the Azilian levels in place, eleven more lying in other stratigraphic units. There is a double dihedral burin on a crested blade with one facet in gray flint, relatively short (length $27.3 \mathrm{~mm}$, width 12.9 and thickness 5.8), with a burin facet on each side, redone several times for one of them (K3A-SU6 square). On two burin spalls, the impact point, the butt and the overhang were completely blunted before the removal, probably when using the burin. Even without traceological analysis, it is evident that all these spalls show prior use of the cutting edges and of long lines of retouches of the edge. In one case (M3B-SU 7, fig. 29, $n^{\circ} 8$ ), the regularity of these working rather suggests the fashioning 
of a neo-crest. The burins were on truncations at least in two cases. 13 to $33.6 \mathrm{~mm}$ long, these spalls rather come from tools on large blades.

In addition to the large granite blocks A, B and C, which will be discussed below, a fragment of elongated pebble of gray micaschist was hammered longitudinally, which removed large flakes on both sides. It measures $33.4 \mathrm{~mm}$ wide and 14.8 thick. Also visible on this tool is a use as an intermediate piece which led to the crushing of the extremity, maybe in an abrading movement. A large unknapped sandstone paving stone, non hammered and unpolished, can also be reported (it measures $96 \mathrm{~mm}$ long).

In a prehistoric collection in the West, a functional spectrum has rarely been so singular: large used blades, Azilian points in various states and many burin spalls, but with only one burin. The more heterogeneous stratigraphic units of Kerbizien excavated in 2011 do not significantly transform this functional spectrum, as far as we can judge. Notably absent are the scrapers on blade ends or circular. These were present in all loci of the recent Azilian site of les Chaloignes in Mozé-sur-Louet (Maineet-Loire; Marchand, 2008; Marchand et al. 2004, 2008, 2009, 2011a). On this site, there were also burins on thick blanks (blades or flakes) and large backed knives in morphological continuity with the points, a type of tool also missing here. While the occupants of the Angers region site stayed about fifty kilometres from the threshold of Poitou and the Paris basin so rich in good quality flint, they opted for laminar debitage made with stone. The products that we studied were much less elongated and regular than those of Kerbizien. In other words, the very laminar nature of the Azilian of the Finistere rock shelter is an affirmed cultural data in spite of the remoteness of flint sources. The intense preparation of the overhangs and the likely use of soft percussion (or semi-soft) also contrast with what was observed on the different loci of les Chaloignes. This technical parameter, as well as the presence of bipoints orients us towards a chronological attribution to an early phase of the Azilian, which we will discuss later. 
Figure 29 - Tools on blade ( $n^{\circ} 1$ à 7$)$ and burin spalls ( ${ }^{\circ} 8$ à 9$)$ from the homogeneous azilian levels (Drawings: G. Marchand).

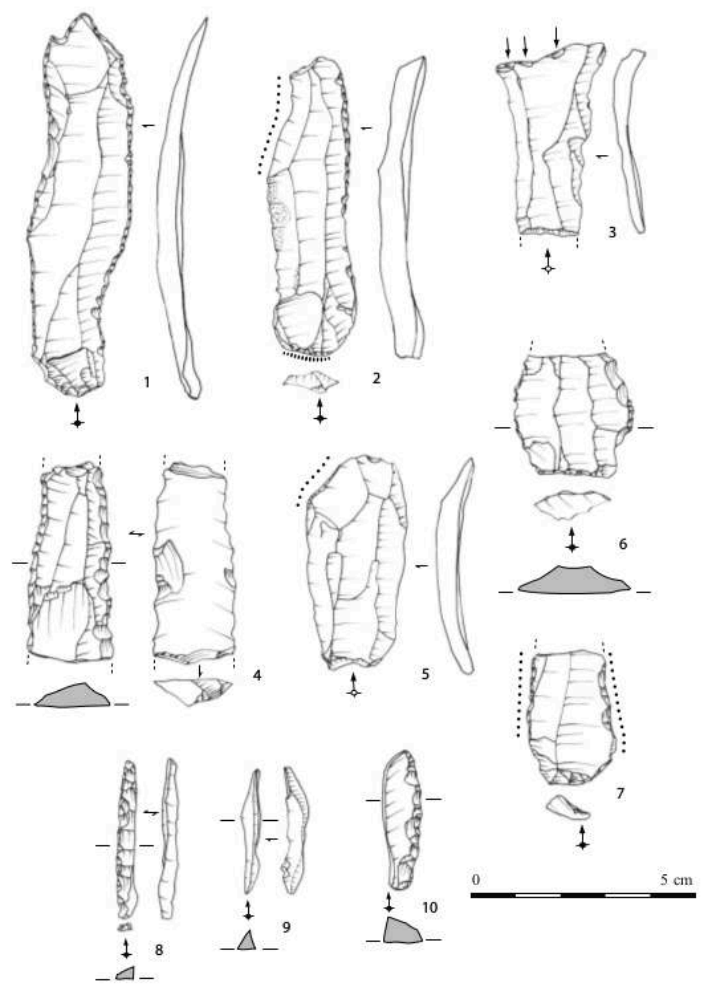

Figure 30 - Blanks (retouched or not) from the homogeneous azilian levels $(\mathrm{N}=314)$.

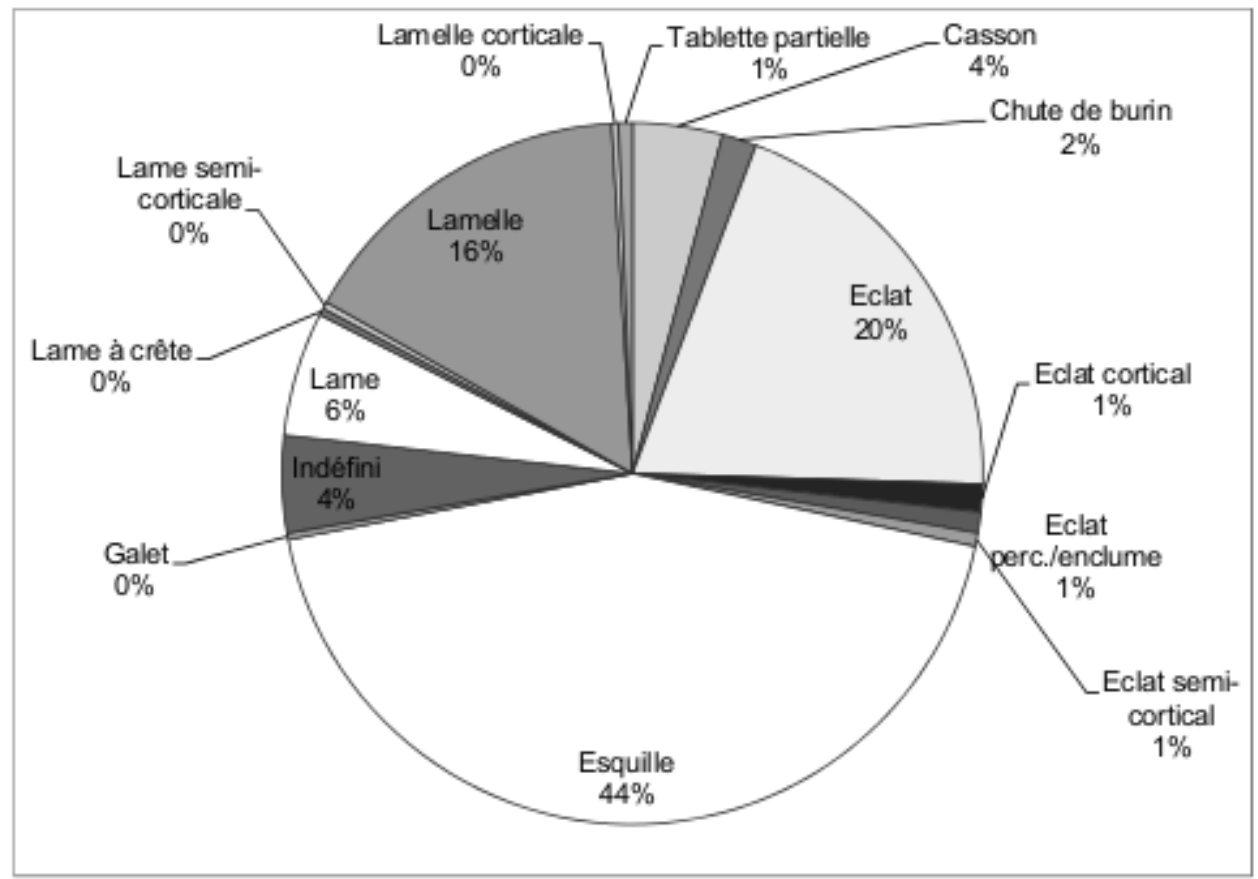


Figure 31 - Width and thickness of the lithic remains from the homogeneous azilian levels.

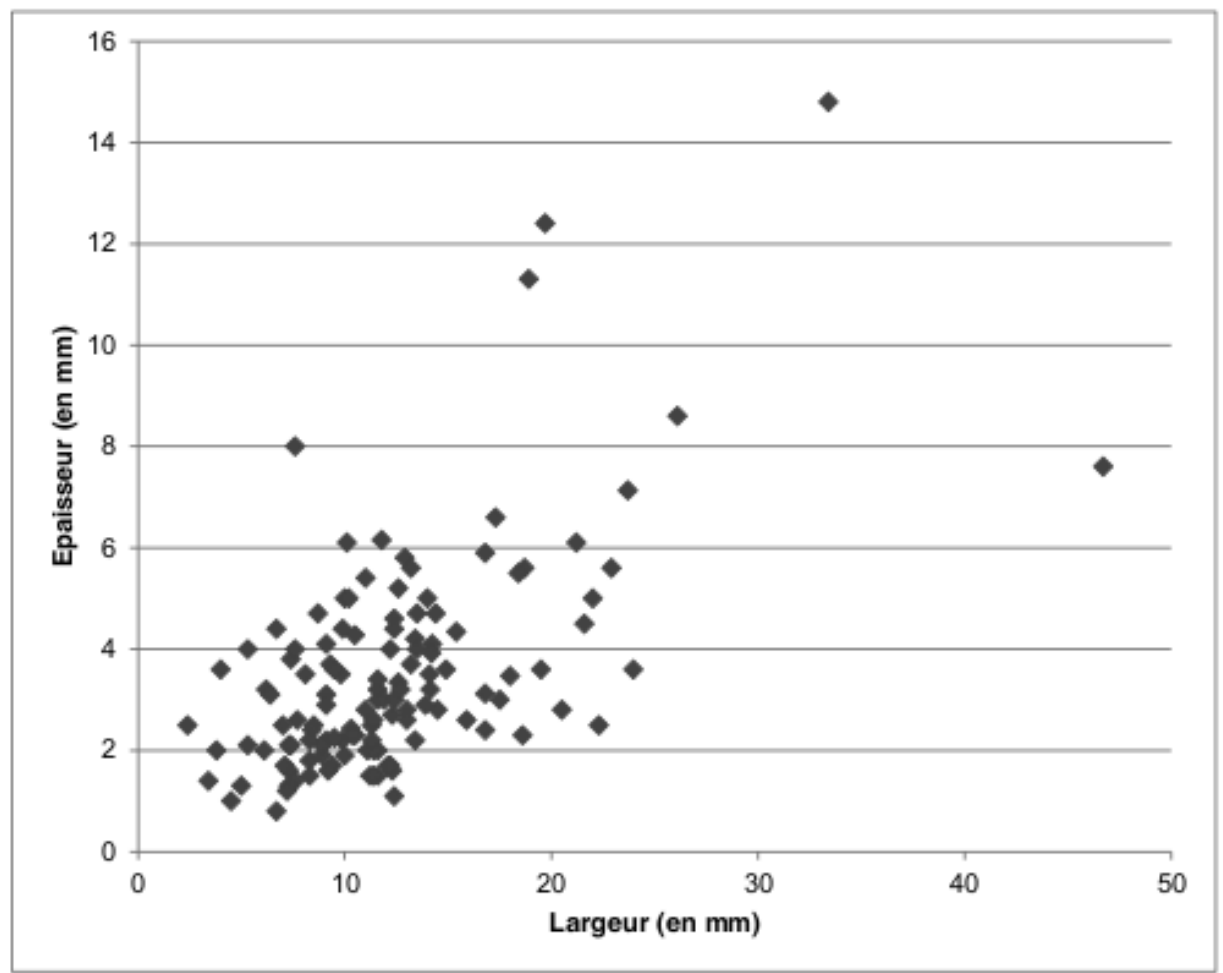

\section{3 - Lithic material of the mixed stratigraphic units}

The removal of much of the sediment inside and in front of the cave paradoxically limited the presence of mixed stratigraphic units: everything has been cleaned! We will point as the main source of information the bed of silt and partially decomposed plant debris that covered the site when we arrived (SU 1), with 239 pieces of lithic material collected therein. Azilian point, narrow bladelet with backed edge of the Early Mesolithic (L6D) and symmetrical trapezoid of the Late Mesolithic (L7B) testify to the obvious presence of occupations of the late Pleistocene and early Holocene in the cave (fig. 32 - table 8, 9 and 10)

Another source of information about "what was", the $20 \mathrm{~cm}$ broad stratigraphic unit all along the wall corresponds to a disturbance that came to affect all levels (SU 13) and condense the information. It yielded 150 pieces. Besides a curved backed projectile inset, an asymmetric trapezoid in flint (K2C) and a symmetrical FL microquartzite trapezoid (N2A) were spotted, both undoubtedly attributable to the second Mesolithic, and a cutting arrow of the middle Neolithic (K3A).

61 Trench $\mathrm{F}$ is more interesting, even if we are not able to strictly distinguish the Azilian assemblages from the Mesolithic ones (fig. 33). With 166 objects per square meter (water sieved), they are moderately dense squares. The same panel of occupation as in the SU 1 or SU 13 is seen. Besides we will also report here a double scraper with side retouch on cortical flake that shows a very marked blunting on one of the edges, which even destroys the angle of attack. According to J. Jacquier (University of Rennes 1), such traces may correspond to the working of skins. 
Figure 32 - Tools from the mixed stratigraphic units (1-5: bottom of the cave ; 6-10: band L). 1 : used blade ; 2 : symmetrical trapeze ; 3 : transverse arrowhead ; 4 : symmetrical trapeze ; 5 : splinted piece ; 6-7 : scrapper ; 8 : azilian point ; 9 : trapeze fragment ; 10 : backed bladelet fragment (drawings: G. Marchand).
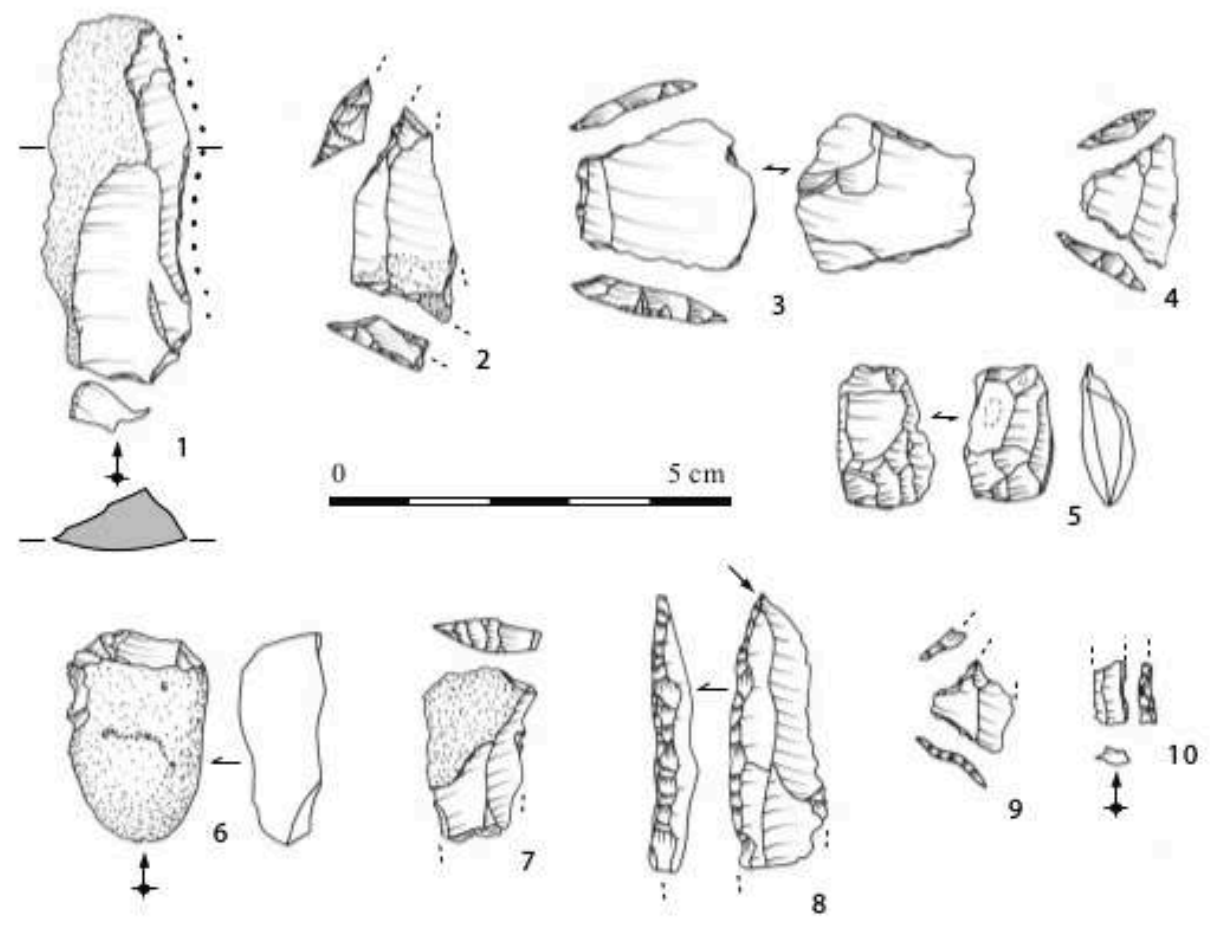

\section{5 - Other lithic elements of the Late Glacial levels}

\section{1 - The shale plaquettes}

The presence of shale plaquettes in a granite shelter is not obvious in a natural way... Water sieving allowed collecting 166 elements in the Azilian squares of the bench at the back and at the angle of the shelter, most being splinters: there are a total of 5 items over $51 \mathrm{~mm}, 51$ objects of a length between 11 and $50 \mathrm{~mm}$ (average length of 20 to 30 $\mathrm{mm}$ ) and 110 fragments smaller than $10 \mathrm{~mm}$. They were found in a secure stratigraphic context for $71 \%$ of them, especially for the largest and most significant elements (fig. 34). There are two types of rock:

- Gray-green satiny micaschist in the form of very thin plaquettes $(5 \mathrm{~mm})$, with a sharp contrast between a gray shiny side and a matte light brown slightly grainy side;

- A denser and thicker dark gray shale, with rust-coloured cleavage plane.

The former is widely prevailing, including three large objects measuring between 65 and $85 \mathrm{~mm}$ long discovered in square N2. Another one was in the SU 7 (burrow) of square M3. They are not pebbles but plaquettes collected around the outcrops themselves, without rolled surfaces. The fractures are neat and it seems possible to refit the fragments between them, but ultimately no re-fitting was possible: the other fragments were elsewhere in the site or possibly beyond. Stockier, the dark gray shale block, measures $92 \mathrm{~mm}$ long, by $29 \mathrm{~mm}$ wide and $19 \mathrm{~mm}$ thick. It is much altered and none of its original surfaces is now visible, contrary to the other rock. 
To determine the cause, we took the advice of Mrs M.-P. Dabard, a geologist at the University of Rennes 1 . The presence of silty laminae and worm holes in the gray-green satiny variety, as well as their general appearance, suggests an origin in the Middle Ordovician (symbols 02 -3-4-5 on the geological map of Huelgoat - No. 276-1988). These Palaeozoic levels surround the granite massif of Huelgoat (Cabanis et al., 1981). They are found at the closest 4 kilometres northeast of the site (east of Berrien), but also on the outer slopes of the mounts bordering the Brennilis basin (fig. 2).

Three shale pebbles engraved with parallel lines were found in 1999 in locus 11 at les Chaloignes, extensive late Azilian site south of Angers (Marchand et al. 2009). Closer to Kerbizien, but without stratigraphic context, engraved shale are also known from the mouth of the Loire in Le Croisic or in Lann Gazel (Trémaouézan). This site discovered by Mr. Le Goffic is 40 kilometres northwest of Kerbizien and yielded an industry of the Azilian in surface collections (Le Goffic 2001). Logically, we thus looked at all the surfaces with a binocular magnifier, without any result. At their collection on the site, they were not washed carelessly with water, but were observed carefully and cleaned very gradually. If there was painting, there is nothing left. Whether the motivations were symbolic or functional, the use of these rocks fits in the range of the Azilian behaviours known elsewhere.

Table 8 - Arrowheads types by stratigraphic units.

\begin{tabular}{|c|c|c|c|c|c|c|c|c|c|c|c|c|c|c|c|c|c|c|c|}
\hline Armature / US & - & $=$ & $m$ & $\div$ & 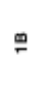 & 으 & $\stackrel{ }{=}$ & $\stackrel{9}{2}$ & 8 & 5 & $\frac{n}{n}$ & $\nabla$ & $\mp$ & $\infty$ & $\bullet$ & n & $\infty$ & 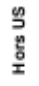 & 홍 \\
\hline $\begin{array}{l}\text { Avrmature } \\
\text { indéfnie }\end{array}$ & 2 & & 1 & & & & 1 & & & 2 & 1 & 1 & & 5 & & 3 & & & 16 \\
\hline $\begin{array}{l}\text { Bipainte } \\
\text { azilienne }\end{array}$ & & & & & & & & & & & & 1 & & & & & 1 & & 2 \\
\hline $\begin{array}{c}\text { Flecche } \\
\text { tranchante }\end{array}$ & & & 1 & & & & & & & & & & & & & & & & 1 \\
\hline $\begin{array}{l}\text { Lamelle à dos } \\
\text { recolligne }\end{array}$ & 1 & & & & & & & & & 1 & 1 & & & & 1 & & & & 4 \\
\hline $\begin{array}{l}\text { Monopainte } \\
\text { azilienne }\end{array}$ & & & & & & & & 1 & & 1 & & 1 & & 1 & & & 1 & & 5 \\
\hline Monotroncature & & & & & & & & & & & & & & & & 1 & & & 1 \\
\hline $\begin{array}{l}\text { Péce à dos } \\
\text { courtite }\end{array}$ & 1 & 2 & 1 & & 1 & 1 & 2 & 2 & & & & 1 & 1 & 2 & & & 2 & 1 & 17 \\
\hline $\begin{array}{l}\text { Pèce à dos } \\
\text { recofligne }\end{array}$ & & & & 1 & & & & & & 1 & & 2 & & & & 1 & 1 & & 6 \\
\hline $\begin{array}{l}\text { Pointe a base } \\
\text { transverse }\end{array}$ & & & & & & & & & & & & & & & & 1 & & & 1 \\
\hline $\begin{array}{l}\text { Trap-asym. (pt } \\
\text { cone-gt rect) }\end{array}$ & & & 1 & & & & & & & & & & & & & & & & 1 \\
\hline Trap indeff. & & & 1 & & & & & & & & & & & & & & & & 1 \\
\hline $\begin{array}{c}\text { Trap. sym. } \\
\text { court (tr } \infty \text { nne) }\end{array}$ & 1 & & 1 & & & & & & 1 & & & & & & & & & & 3 \\
\hline $\begin{array}{l}\text { Trap. sym. } \\
\text { coutt (t rect) }\end{array}$ & 1 & & & & & & & & & & 1 & & & & & & & 1 & 3 \\
\hline $\begin{array}{l}\text { Trange } \\
\text { scalene }\end{array}$ & & & & & & & & & & 1 & & & & & & & & & 1 \\
\hline Total & 6 & 2 & 6 & 1 & 1 & 1 & 3 & 3 & 1 & 6 & 3 & 6 & 1 & 8 & 1 & 6 & 5 & 2 & 62 \\
\hline
\end{tabular}


Table 9 - Arrowheads types by raw materials (all stratigraphic units).

\begin{tabular}{|c|c|c|c|c|c|c|c|c|c|c|c|c|c|c|}
\hline Armature / US & 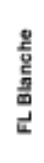 & $\begin{array}{l}\frac{n}{5} \\
\frac{d}{2} \\
\frac{1}{2}\end{array}$ & 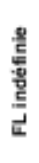 & 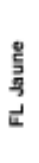 & 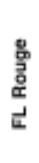 & 毞 & $\begin{array}{l}\text { 들 } \\
\text { a } \\
\text { ฮِ } \\
\text { 心 }\end{array}$ & 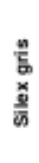 & 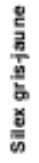 & 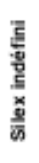 & 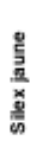 & 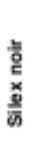 & $\begin{array}{l}\frac{g}{\text { पू }} \\
\frac{\pi}{0} \\
\frac{a}{\pi} \\
0\end{array}$ & 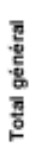 \\
\hline Avmature indéfinie & 2 & & & 1 & & & 2 & 4 & & 6 & 1 & & & 16 \\
\hline Bipainte azilienne & & & & & & & & 1 & 1 & & & & & 2 \\
\hline Flèche tranchante & & & & & & & & & & & 1 & & & 1 \\
\hline Lamele à dos recsligne & & & 1 & & & 2 & & & & & 1 & & & 4 \\
\hline Manopoirte azlienne & & & & & & 1 & & 2 & 1 & 1 & & & & 5 \\
\hline Monotroncature & & & & & & & & & & & 1 & & & 1 \\
\hline Pièce à das courbe & & 1 & & & & & 2 & 10 & 2 & 1 & 1 & & & 17 \\
\hline Plèce à das rectiligne & & & & & & & 1 & 5 & & & & & & 6 \\
\hline Poirte à tase transwerse & & & & & & & & & & 1 & & & & 1 \\
\hline $\begin{array}{l}\text { Trap. asym. (pt canc - g! } \\
\text { rect) }\end{array}$ & & & & & & & & 1 & & & & & & 1 \\
\hline Trap. indéf. & & & & & & & & 1 & & & & & & 1 \\
\hline Trap. sym. court (tir cone) & & & & & 1 & & & & & 1 & & & 1 & 3 \\
\hline Trap. sym. court (tr rect) & & & & & & & & 1 & & 1 & & & 1 & 3 \\
\hline Triangle scalène & & & & & & & & & & & & 1 & & 1 \\
\hline Total général & 2 & 1 & 1 & 1 & 1 & 3 & 5 & 25 & 4 & 11 & 5 & 1 & 2 & 62 \\
\hline
\end{tabular}

\section{2 - Knapped granite blocks}

More originals in these cultural contexts, three large blocks of coarse granite, from local origin, were discovered in the middle of the SU 5 in squares L2, L3, K2 and K3 (fig. 13 and 15). Surprising as it may seem, they were clearly knapped, as shown by refitting:

- Block A is a large granite flake, $17 \mathrm{~cm}$ long, $11 \mathrm{~cm}$ wide and $7 \mathrm{~cm}$ thick; it weighs $1.2 \mathrm{~kg}$. A butt and a marked impact point are visible. It refits with block B, which was found $6 \mathrm{~cm}$ to the west;

- Block B is $43 \mathrm{~cm}$ long by $21 \mathrm{~cm}$ wide and $13 \mathrm{~cm}$ thick; it weighs $15.5 \mathrm{~kg}$ (fig. 35 and 36 ). Besides flake A, knapped in the direction of the length, there are obvious traces of shaping all around.

- Block C laid $10 \mathrm{~cm}$ north of block B (fig. 37 and 38). It does not refit with the others, but the removal negatives of six flakes on the upper side should be noted, knapped from the tearing face. The removals are short $(7 \mathrm{~cm})$ and wide. It is very roughly quadrangular in shape, 26 $\mathrm{cm}$ long by $21 \mathrm{~cm}$ wide and $8 \mathrm{~cm}$ thick. It weighs $7 \mathrm{~kg}$.

Perhaps there were small flakes of granite around, but they may have disintegrated or been mixed up by the excavators with a few small fragments of granite scattered in the sand. Let's not forget that these blocks come directly from the wall, as they come from an "onion peel" type of erosion. The aim of these massive debitage, with unmistakable scars, is puzzling... It is possibly only an anecdotal activity of the Azilian occupants. 
Table 10 - Tools types by raw materials (all stratigraphic units).

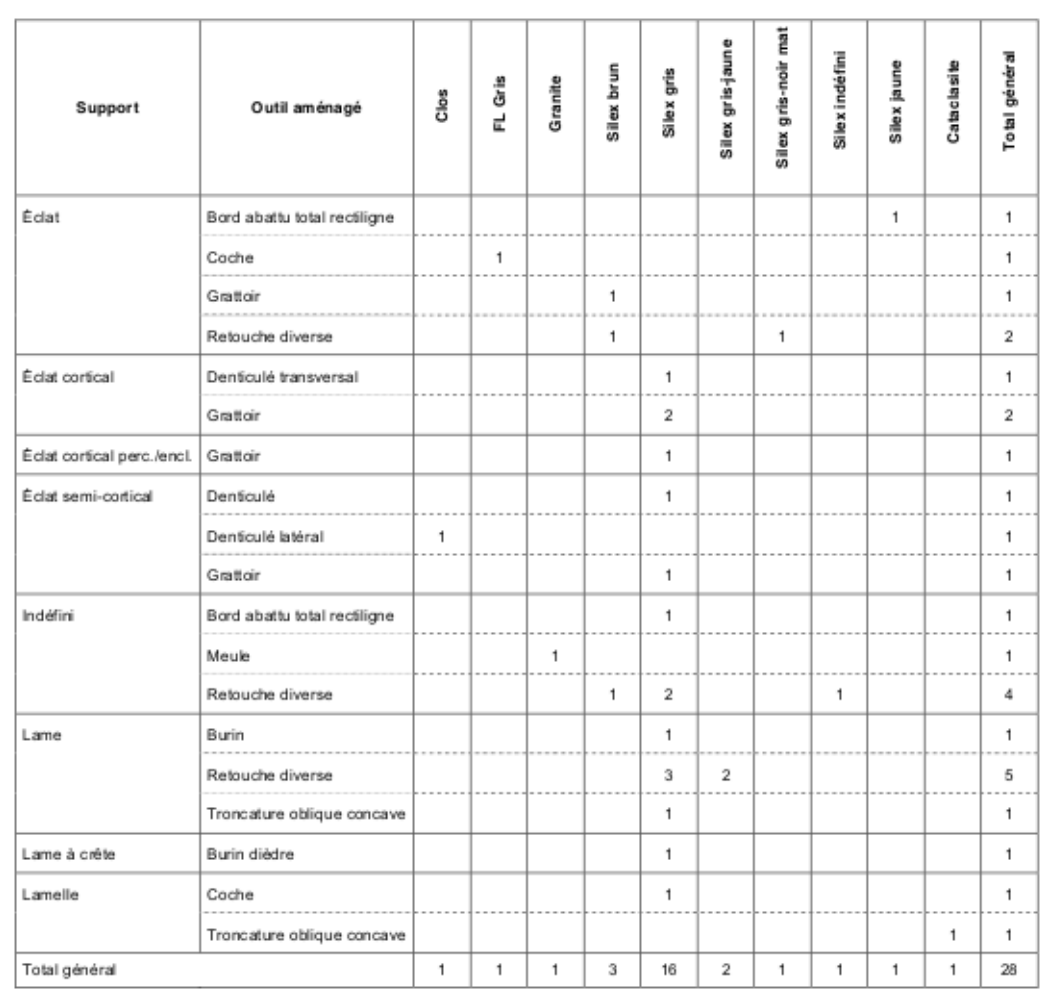

\section{6 - Originality of the Azilian in Kerbizien}

\section{1 - A still fragile network of knowledge in western France}

The remarkable cave in the monolithic block of Kerbizien was the site of human occupations in the Azilian and of several Mesolithic phases arranged in stratigraphy on about a meter thick. A slag was dated from the early Middle Ages, another period when the rock-shelter was particularly interesting. The destruction of such a sequence is obviously regrettable. Our operation in 2011 nevertheless allowed identifying and excavating in totality the remains of a particularly rare Azilian occupation in the region. If the radiometric analysis of a charcoal only allowed detecting a Neolithic intrusion, chronological refining remains possible by typological analogies.

Laminar debitage, burins and curved backed points obviously indicate the Azilian, a technical entity whose best point of comparison in the West is the site of les Chaloignes, by the town of Mozé-sur-Louet in the Maine-et-Loire region (Marchand et al. 2008, 2009). Alas, in the Pays-de-la-Loire, as in Brittany, no correct radiocarbon dating has so far been obtained on these groups and we must rely on comparisons with other regions to establish the basis of a chronological framework. In the West, recent analyses around the reference stratigraphy of Bois-Ragot (Gouex, in the Vienne region) have questioned the assertion of the appearance of curved backed points in the Magdalenian of layer 5 dated to the interval 13,500 - 12,400 BC (Chollet and Dujardin, 2005). These very emblematic points qualify however unquestionably the Azilian south of the Loire and the Federmesser around the Seine, between 12,000 and 11,000 BC (11,800 - 10,800 BP) throughout the Alleröd interstadial, and perhaps beyond. At the 
scale of Brittany, we have identified 48 final Palaeolithic assemblages, mostly mixed with other components (Marchand et al. 2004).

Three other sites excavated in the Finistere region demonstrate the Azilian presence: the Roc'h Toul cave in Guiclan, Enez Guennoc in Landéda and the shelter of le Rocher de l'Impératrice in Plougastel-Daoulas (fig. 39). The former is a cave that plunges into an Armorican sandstone massive on a steep slope. It was explored in 1868 and 1869 by Dr Le Hir, then by C. Benard, also called Le Pontois, and finally by E. Morel; the material was studied by G. Laplace (Laplace-Jauretche 1957), by J.-L. Monnier (Giot et al. 1977; Monnier 1980) and finally by N. Naudinot (2010), the examined number of objects decreasing with various losses, borrowing or thefts... On this site, the presence of curved backed bipoints, of endscrapers on blade or on flake and of many denticulate flakes can be noted. The burins appear to be rare, contrary to what was said one time. The debitage was done with a soft hammer, from two opposite striking platforms (Naudinot 2010). The objects preserved today are in flint, mostly from marine pebbles gathered on the foreshore. Yet some native cortex show long distances import, perhaps from the Jurassic margins of the Armorican Massif (at least $300 \mathrm{~km}$ to the east). Eocene sandstone elements - including an Azilian point - testify on the opposite of a supplying from the resources of the massif. The bipoints, the high rate of burins or the endscrapers on blades direct us to a fairly early phase of the Azilian (provided that such an ancient excavation allows this type of reasoning), and therefore a clear comparison with Kerbizien.

The second excavated site, Enez Guennoc, was discovered on a present-day island during P. R. Giot's excavations. The spreading of lithic material was in two areas of the main excavation, in a level underlying Neolithic cairns (Monnier 1980). Traditionally, since J.-L. Monnier's excavations, Enez Guennoc has been described as a "transition" site, with non-geometric microliths mingling with backed points. A new study by S. Michel and N. Naudinot has shown that it was mixed-up in a very thin palaeosol (Michel and Naudinot 2009).

The third site, the shelter of le Rocher de l'Impératrice, is located at the foot of a large quartzite-sandstone cliff that borders the southern Elorn valley, near Brest. The prehistoric occupation was discovered in 1991 by M. Le Goffic in the waste soil from the illegal work to set up a climbing wall. The objects found during the sieving of the waste soil by the inventor consisted mainly of tools (burins, pièces esquillées and bipoints), with a strong laminar component. The site was the subject of survey pits in July 2013 followed by excavations in 2014 under the direction of N. Naudinot, who identified an early Azilian level.

By surface collections, other sites or evidence of sites are already known in Brittany, including several major groups:

- Lann Gazel (Trémaouézan, Finistère; Le Goffic 2001)

- Quillien (Le Cloître Saint-Thégonnec, Finistère; Gouletquer and Leopold, 1991)

- Runigou / Notenno (Trébeurden; Chevalier 1999)

- Roc'h Glas (Penvenan, Cote d'Armor; Chevalier 1999)

- Le Perzo (Neuillac, Morbihan; Marchand et al. 2004),

- l'Anse de Landroannec (Mur-de-Bretagne, unpublished O. Kayser and G. Tournay).

74 In the evolution of the shapes of projectile insets across the French territory, the older age of bipoints industries over monopoints ones is a fact that seems to be accepted and on which we have already relied to offer dates for the regional Azilian (Marchand et al. 
2004; Marchand 2008). For example, this can be observed in the stratigraphy of BoisRagot (Gouex, Vienne region; Chollet and Dujardin 2005), as in the one of Pont d'Ambon (Bourdeilles, Dordogne; Célérier 1994, 1998). More recently, this decidedly robust key for dating was confirmed by a group of researchers working on the southwest of France, both in the Aquitaine Basin and in the Pyrenees (Fat Cheung et al. 2014).

Most of the Armorican sites mentioned above clearly belong to the monopoints phase, that is to say the second part of the Alleröd. However Roc'h Toul and le Rocher de l'Impératrice would testify of the older bipoints phase. It would be the same for Kerbizien. The large retouched blades, used many times, are an original aspect of the series. Such tools are particularly well represented in the lower level of Le Closeau (Rueil-Malmaison, Hauts-de-Seine), which remains the main reference of the technical entity in northern France (Bodu 1995, 2000; Bodu and Valentin 1997). This level was placed at the end of the fourteenth and the beginning of the thirteenth millennium $B C$ that is to say at the end of the Bölling, both by a dozen radiocarbon dates on animal bones, and by the stratigraphic data. Loci 4 and 46 are the main settlement areas on the lower level, with large limestone blocks arranged around a central space occupied by a hearth (Bodu 2000). Among the abundant tools, P. Bodu and L. Mevel isolated large blades with intentional retouching that are found inside the structured spaces of this site and not in peripheral workshops, in a similar manner than the raw blades used (Bodu and Mevel 2008). These large blanks whose cutting edge was reworked several times would be dedicated to the scraping of hides. The Azilian bipoints clearly dominate in this lower level in Le Closeau and some are also found in Kerbizien. Laminar production or burins on blades are also converging elements with Kerbizien. There is however a high rate of endscrapers in Le Closeau while these tools are missing from our sample.

We can also mention throughout the region the presence during the Azilian of some points with angular back in northern Finistère, for example on the site of Lann Gazel (Le Goffic 2001), together with the Azilian monopoints and bipoints. This association reminds of the "penknife points" assemblages (also known as Grundy points) present in the south of England. They are posterior to the Creswellian and contemporary of the Alleröd (Barton, Roberts 1997). These comparisons encourage considering differently the human geography around the mouth of the broad Palaeo-Channel estuary, with perhaps a different territorial organisation from the rest of the region. Mr. Le Goffic has also clearly shown that the flint used in Lann Gazel came directly from outcrops dated of the Cretaceous, inaccessible today due to the Flandrian transgression.

The large retouched blades and the bipoints would incline us to attribute the Kerbizien assemblage to an early phase of the Azilian, only found in Roc'h Toul and at le Rocher de l'Impératrice in the regional framework. Many reservations must obviously be issued. The diversity of the curved backed point blanks encourages considering multiple visits during the Azilian. A large curved backed point with a retouched base found in F5 (fig. 33, No. 1) can be described as a Malaurie point, indicating an occupation or at least a visit at the end of the Azilian. Thus, we excavated an accretion of Azilian occupations in the remains of a slightly dilated level, with relatively homogeneous functional characteristics between them. Glacial environments has increased since the late 1990s in Brittany and in the Pays-dela-Loire (Barbier 1999; Barbier and Visset 1999 Marguerie 2000; Gaudin 2004). The 
climate improvement of the Bölling/Alleröd appears in three peat bogs of the northeast of the Mayenne region: Saint-Ursin (Lignières-Orgères) and Le Fourneau (Pré-en-Pail) (Barbier 1999). It was also detected in Ille-et-Vilaine, in the Palaeo-channel of the valley of the Vilaine, in Rennes and in La Minette (Saint-Sauveur-des-Landes). In contrast to the situation in the continental area, pollen analysis shows the existence of a steppe with Poaceae, that is to say a very open environment where the pine holds a very small role in the west, while the east of the Massif is more marked by birch. During the Younger Dryas cooling, the steppe characteristic remained very pronounced and the forest cover only settled very gradually in the Preboreal (Gaudin 2004 - p 277-282.).

Figure 33 - Tools from the stratigraphic units 30 and 31 of the trench $F$. 1: curve backed point (Malaurie point) ; 2-3 : backed bladelets fragments ; 4 : scalene triangle; $5:$ trapeze ; $6:$ scrapper ; 7 : truncation on bladelet ; 8 : denticulate flake $; 9$ : symmetrical trapeze ; 0 : splinted piece $; 11$ : used blad (Drawings : G. Marchand).
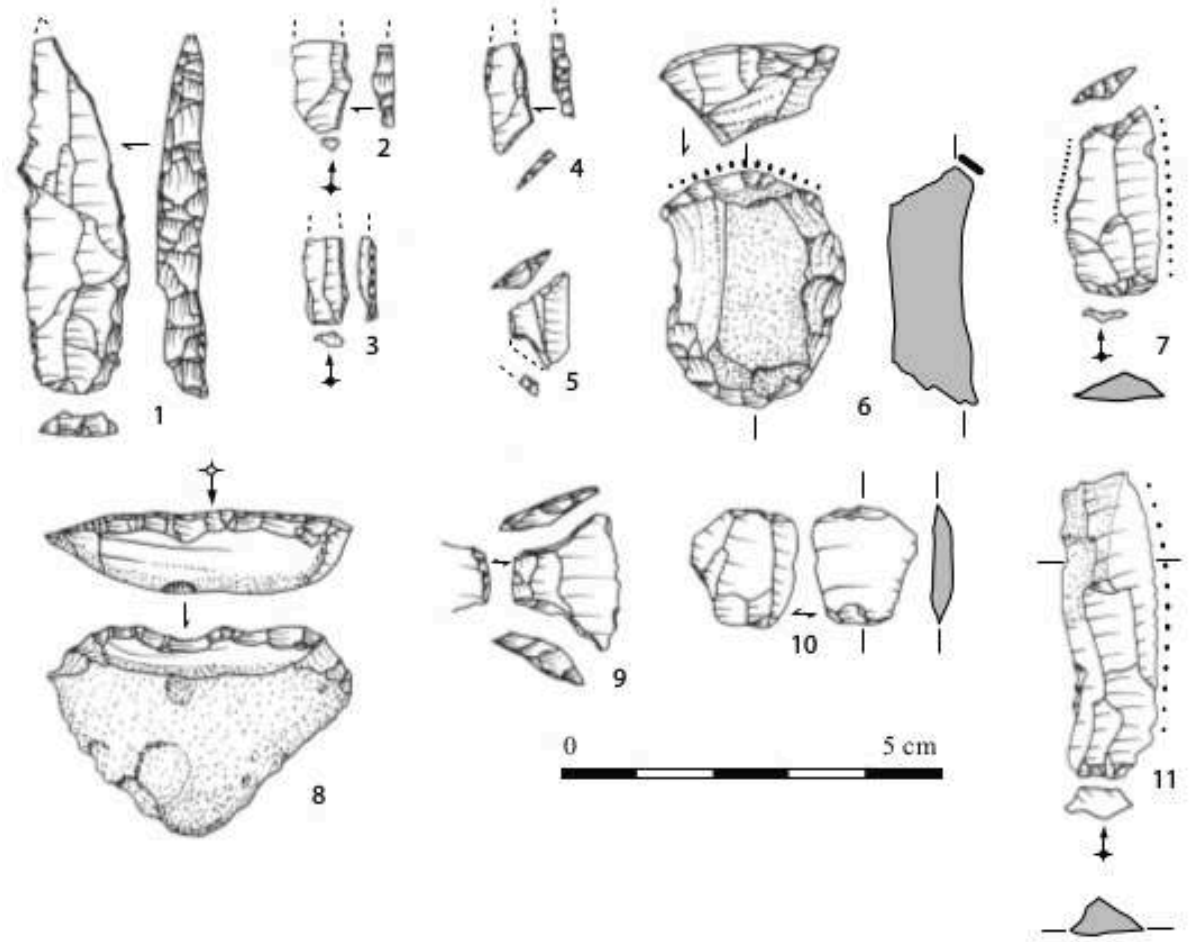
Figure 34 - Pictures of the schist plates (from top to bottom: N2A US 5, M3D US 7, J5D US 8) (pictures : G. Marchand).

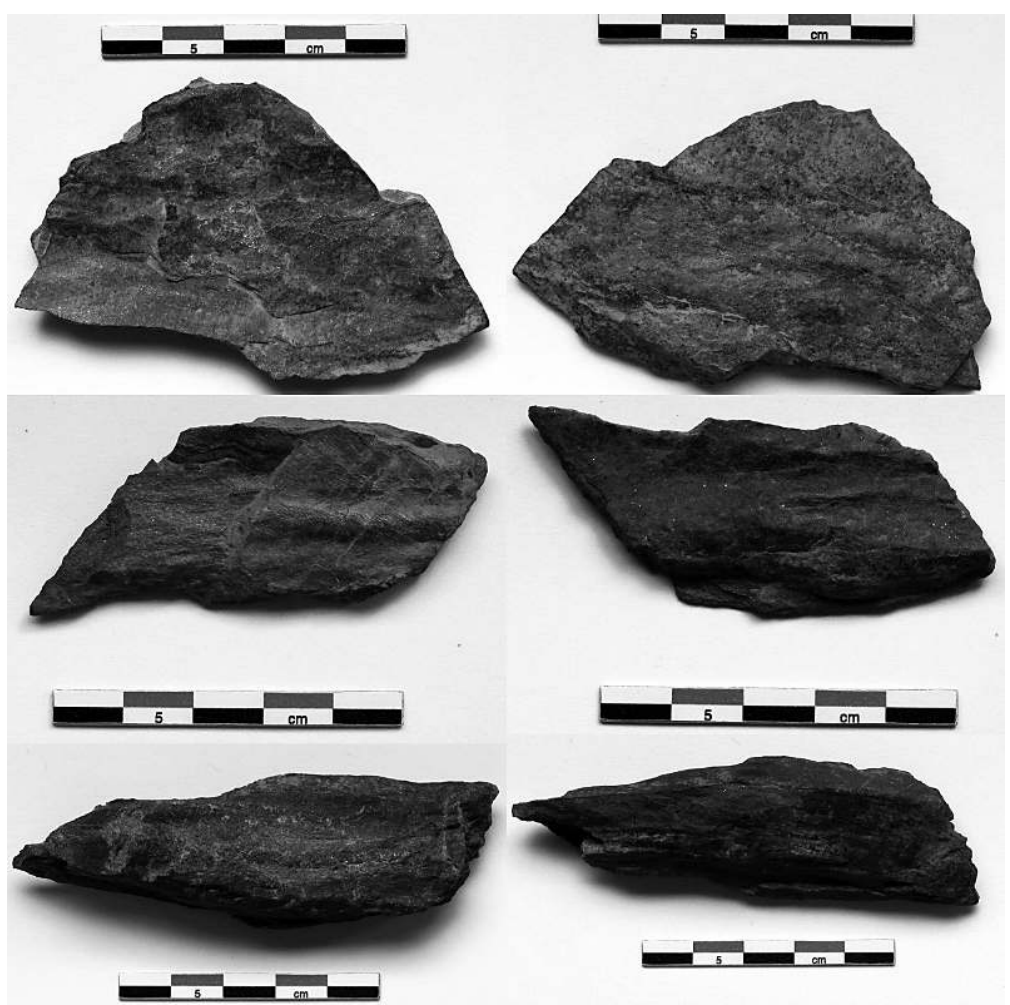

Figure 35 - Block B. The notches around the block are made to regularize the shape (picture: $\mathbf{G}$. Marchand).

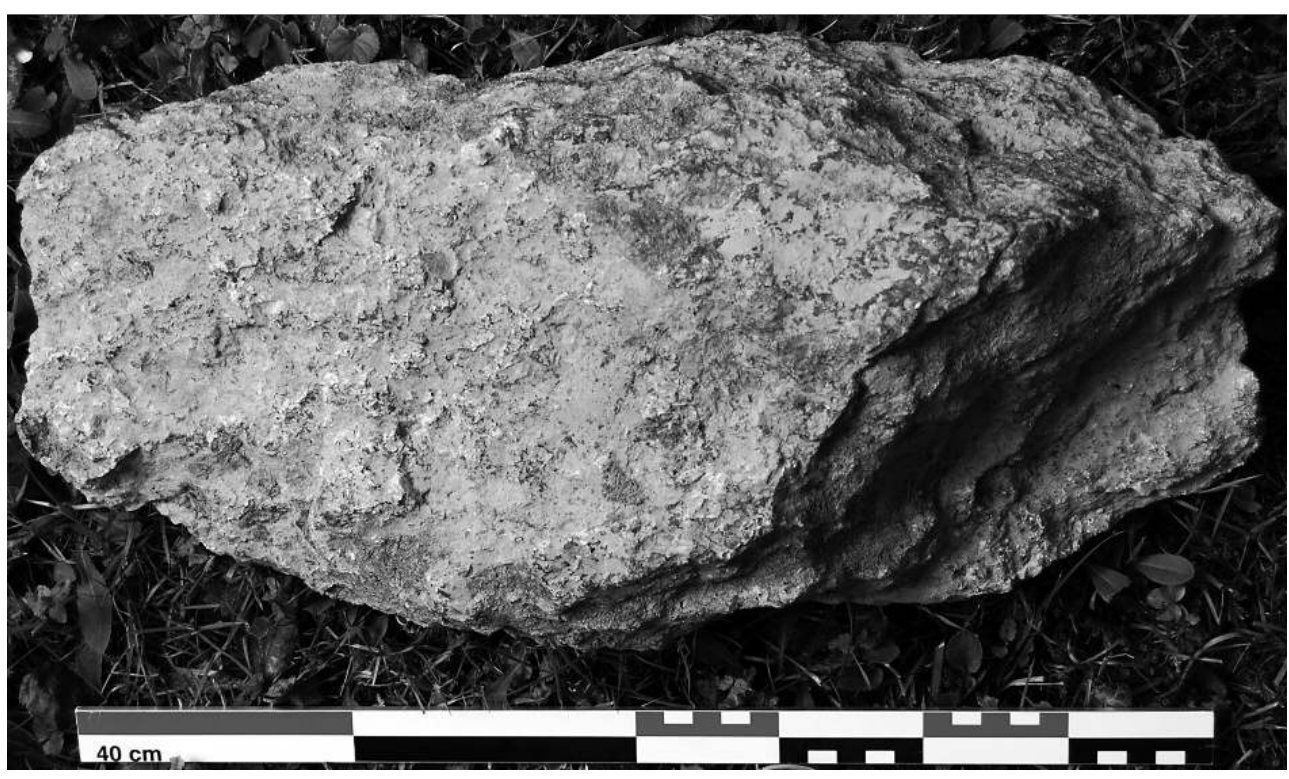


Figure 36 - Profile of the block B (picture: G. Marchand).

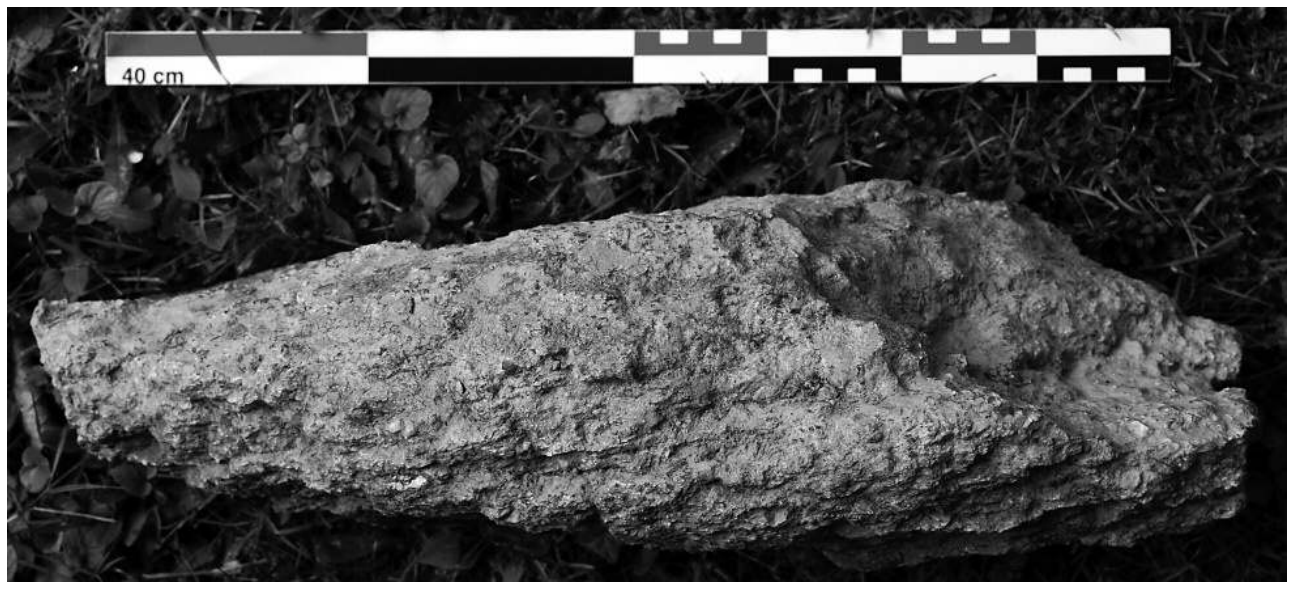

Figure 37 - The block C with its peripheral flakes (picture: G. Marchand).

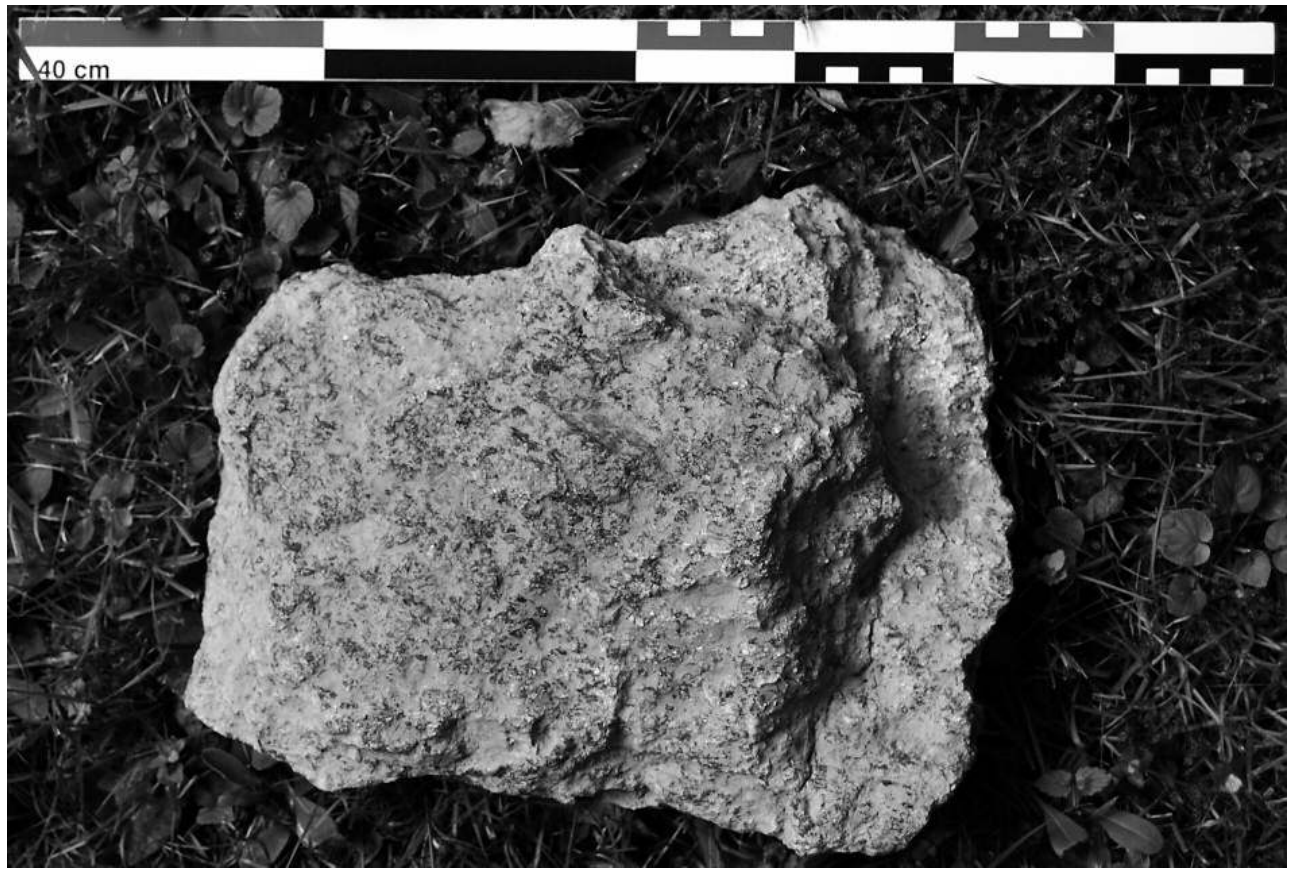


Figure 38 - Profile of the block C (picture: G. Marchand).

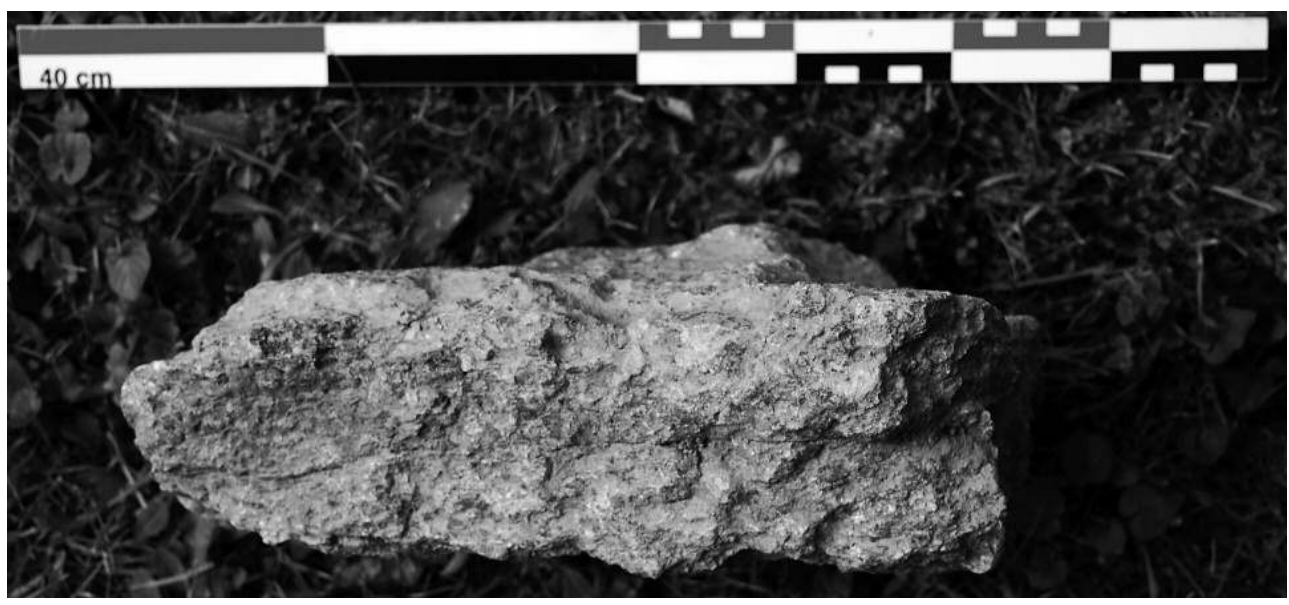

Figure 39 - Location of the Kerbizien rock shelter (black star) with the main azilian and post-azilian sites in Finistère and the : main regional raw materials used for knapping (Ge : Eocene sandstone ; UT : Tréméven ultramylonite; CM : Mikaël cataclasite; Clos : Clos chalcedony ; FL : ForestLanderneau microquartzite). Name of the archaeological sites : 1 : Kerbizien (Huelgoat) ; 2 : Quillien (Le Cloitre-Saint-Thégonnec) ; 3 : Lann-Gazel (Trémaouézan) ; 4 : le Rocher de l'Impératrice (Plougastel-Daoulas) ; 5 : Roc'h Toul (Guiclan) ; 6 : le Clos (Plourin-lès-Morlaix) ; 7 : Enez Guennoc (Landéda) ; 8 : Runigou/Notenno (Trébeurden) (CAD : Philippe Forré and Grégor Marchand).

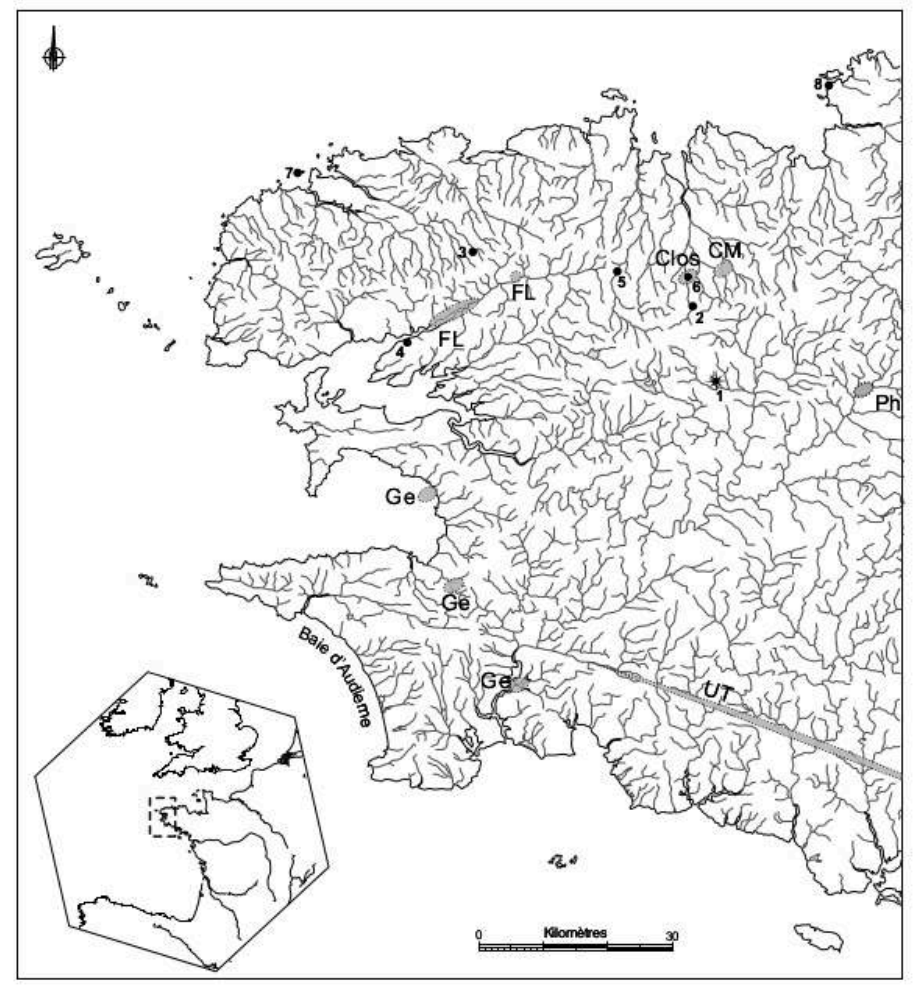

\section{2 - Very specific functional parameters}

There are certainly too many gaps arising from the site conditions in the Azilian assemblage of Kerbizien for us to understand the nature of the successive occupations. The abandonment of large flint blades while this material is so rare in the Centre of Brittany should attract our attention. In such a context of geological shortage, their 
non-conversion could signal a degree of human mobility, people not loading themselves with worn tools when leaving and not having the opportunity of reusing them. The absence of burin is probably related to the fragmentary nature of the sample, as there are 16 burin spalls, some showing several resharpening and a great care in their knapping. Archaeological gaps could also explain the absence of endscrapers. In terms of interventions on the mineral matter, on the one hand we should note the import of thin shale plaquettes from several kilometres for an unknown purpose, on the other hand, the debitage of large local granite plaques for equally mysterious purposes. This assemblage presents a very original functional structure, which inevitably evokes a logistics station of highly mobile groups. It is then possible to imagine hunting expeditions in the hilly area in the centre of the Breton peninsula. The use of local rocks (microquartzite from La Forest-Landerneau, ultramylonite from Mikael and Clos chalcedony), even in small amounts, is also an essential information that encourages to believe in a good surveying of the area by these prehistoric people. In other words, this is not hunting expeditions from the great plains of the eastern Armorican Massif, but more complex economic models based on a thorough knowledge of this hilly area. What would be their stations? Also occupied in the early Azilian, Roc'h Toul cave is $21 \mathrm{~km}$ northwest of the Kerbizien rock-shelter and offers more space for a long occupation: the destruction of its filling by previous excavations does little to allow us to reflect on the actual functional status of these occupations in the Late Glacial. The shelter of le Rocher de l'Impératrice in PlougastelDaoulas (Finistère), discovered by M. Le Goffic and currently excavated by N. Naudinot, is another possible station, $45 \mathrm{~km}$ west of Kerbizien. One can of course add the open air site of Lann Gazel in Trémaouézan in this chrono-cultural atmosphere (Le Goffic 2001). Therefore some points do exist, mainly caves, which scarcely mark the Late Glacial landscapes that palynology describes as very open. But little by little the picture is revealing itself...

\section{BIBLIOGRAPHY}

BARBIER D. 1999 - Histoire de la végétation du nord-mayennais de la fin du Weichsélien à l'aube $\mathrm{du}$ XXIème siècle. Mise en évidence d'un Tardiglaciaire armoricain. Interactions Homme-Milieu. GEMINA, 2 vol.

BARBIER D., VISSET L.1999 - Les spécificités d'un Tardiglaciaire armoricain : étude pollinique synthétique à partir de trois tourbières du nord-est mayennais (France). Quaternaire, 11 (2), p. 99-106.

BARTON R.N.E., ROBERTS A.J. 1997 - Systèmes économiques et modalités techniques dans l'ouest de la Grande- Bretagne au Tardiglaciaire. In : Fagnart J.-P. et Thévenin A. Le Tardiglaciaire en Europe du Nord- Ouest. Actes du 119 ème Congrès national des Sociétés historiques et scientifiques. Amiens, 1994, p. 198-207.

BODU P. 1995 - Un gisement à Ferdermesser sur les bords de la Seine : le « Closeau » à RueilMalmaison (Hauts-de-Seine), Bulletin de la Société Préhistorique française, T. 92, n4, p. 451-456. 
BODU P. 2000 - Les faciès tardiglaciaires à grandes lames rectilignes et les ensembles à pointes de Malaurie dans le sud du Bassin parisien : quelques réflexions à partir de l'exemple du gisement du Closeau (Hauts-de-Seine), In : Crotti P. dir., Meso'97. Table-ronde sur l'Epipaléolithique et le Mésolithique, Lausanne, novembre 1997, p. 9-28.

BODU P., MEVEL L. 2008 - Enquête autour des lames tranchantes de l'Azilien ancien. Le cas du niveau inférieur du Closeau (Rueil-Malmaison, Hauts-de-Seine, France). L'anthropologie, 112, 4, p. 509-543.

BODU P., VALENTIN B. 1997 - Groupes à Federmesser ou aziliens dans le sud et l'ouest du Bassin parisien. Propositions pour un modèle d'évolution, Bulletin de la Société Préhistorique française, 94, 3, p. 341-347.

BRIARD J., MONNIER J.L. 1976 - Tumulus armoricains de l'Age du Bronze et couverture loessique weichsélienne. Bull. Soc. géol. minéral. Bretagne, 1976, VIII, 75-88 .

CABANIS B. et al. 1981 - Carte et notice explicative de la feuille Morlaix à 1/50 000. BRGM, 48 p. (et carte).

CÉLÉRIER G. 1994 - L'abri-sous-roche de Pont-d'Ambon à Bourdeilles (Dordogne), GalliaPréhistoire, 36, p. 65-144.

CÉLÉRIER G. 1998 - L'abri sous-roche de Pont d'Ambon à Bourdeilles (Dordogne, France). Perspective synthétique, Paleo, 10, p. 233-264.

CHEVALIER G. 1999 - De nouveaux indices du Paléolithique supérieur sur le littoral trégorrois (Côtes d'Armor). Bulletin de l'AMARAI, 12, p. 29-49.

CHOLLET A., DUJARDIN V. dir. 2005 - La grotte du Bois-Ragot à Gouex (Vienne). Magdalénien et Azilien. Essais sur les hommes et leur environnement, Société Préhistorique Française, Mémoire 38, $427 \mathrm{p}$.

FAT CHEUNG C., CHEVALLIER A., BONNET-JACQUEMENT P., LANGLAIS M., FERRIÉ J.-G., COSTAMAGNO S., KUNTZ D., LAROULANDIE V., MALLYE J.-B., VALDEYRON N., BALLISTA S. 2014 Comparaison des séquences aziliennes entre Dordogne et Pyrénées: état des travaux en cours, In : Langlais M. ; Naudinot N. ; Peresani M. (dir.), Les sociétés de l'Allerød et du Dryas récent entre Atlantique et Méditerranée, Actes de la séance de la Société préhistorique française de Bordeaux, 24-25 mai 2012, Mémoire de la Société Préhistorique Française, 3, p. 17-44.

GAUDIN L. 2004 - Les transformations spatio-temporelles de la végétation du nord-ouest de la France depuis la fin de la dernière glaciation. Reconstitutions paléo-paysagères. Thèse de doctorat de l'Université de Rennes 1, 2 volumes, 763 p.

GIOT, P.-R., HALLEGOUET, B., MONNIER, J.-L. 1977 - Le Paléolithique supérieur du Pays de Léon (Finistère). Les gisements de Roc'h Toul, Parc ar Plenen (Guiclan), Enez Guennoc (Landéda) et la Forest-Landerneau, L'anthropologie, 81, 2, p. 201-234.

GOULETQUER P., LÉOPOLD P. 1991 - État provisoire d'une prospection de longue durée : le site mésolithique de Quillien (Le Cloître de Saint-Thégonnec, Finistère), Revue Archéologique de l'Ouest, $n^{\circ} 8$, p. 61-83.

GOULETQUER P., LEOPOLD P., avec la collaboration de E. BAUDOUIN, P. JEZEQUEL ET M.-F. DIETSCH 1994 - Autopsie d'un site mésolithique, Le Clos (Plourin-les-Morlaix, Finistère). Revue Archéologique de l'Ouest, 11, p. 31-52.

GOULETQUER P., KAYSER O., LE GOFFIC M., MARCHAND G. 1997 - Approche géographique du Mésolithique de la Bretagne, In : Fagnard J.-P., Thévenin A. dir., Le Tardiglaciaire en Europe du nordouest, Actes du 119 ème congrès national des Sociétés historiques et scientifiques, Amiens 1994. Editions du Comité des travaux historiques et scientifiques, p. 279-292. 
GOULETQUER P., KAYSER O., LE GOFFIC M., LÉOPOLD P., MARCHAND G., MOULLEC J.-M. 1996 - Où sont passés les Mésolithiques côtiers bretons ? Bilan 1985-1995 des prospections de surface dans le Finistère, Revue Archéologique de l'Ouest, 13, p. 5-30.

KELLY R. 2007 - The foraging spectrum. Diversity in Hunter-Gatherer lifeways. New York, Percheron Press, $446 \mathrm{p}$.

LAPLACE-JAURETCHE G. 1957 - Les industries de Roc'h Toul et Par-ar-Plenen en Guiclan (Finistère), Bulletin de la Société Préhistorique Française, LIV, 7-8, p. 422-438.

LE GOFFIC M. 1990 - L'abri-sous-roche de Pont-Glas en Plounéour-Ménez. Bulletin de la Société archéologique du Finistère, 119, p. 61-69.

LE GOFFIC M. 2001 - Trémaouézan, Lann-Gazel. In : Notice d'archéologie finistérienne, Bulletin de la Société Archéologique du Finistère, tome CXXX, p. 98-100.

LEFORT J.-P., MONNIER J.-L., DANUKALOVA G., à paraître - Deflation and Transportation of the upper Pleistocene loess particles by Katabatic winds during the low stands of the English Channel: their control on the NeandertalianS and Homo Sapiens dwelling. Quaternary International.

MARCHAND G. 2008 - Dynamique des changements techniques sur les marges du Massif armoricain de l'Azilien au Premier Mésolithique, In : J-P. Fagnart, A. Thévenin, Th. Ducrocq, B. Souffi et P. Coudret dir., Le début du Mésolithique en Europe du Nord-Ouest. Actes de la table ronde d'Amiens (9 et 10 octobre 2004), p 52-64.

MARCHAND G. 2012 - Différences de potentiels géologiques entre Massifs cristallins et Bassins sédimentaires, In : Marchand G. et Querré G. (dir), Roches et sociétés de la Préhistoire entre Massifs cristallins et Bassins sédimentaires. Rennes : Presses Universitaires de Rennes, Collection Archéologie et Cultures, p. 9-28.

MARCHAND G. 2014 - Préhistoire atlantique. Fonctionnement et évolution des sociétés. Arles : Éditions Errance, $520 \mathrm{p}$.

MARCHAND G., LE GOFFIC M. 2009 - Give us some small sites please! Report on the first year of excavations in the rock shelter of Pont-Glas (Plouneour-Menez, Finistère, France), Mesolithic Miscellany, 19, 2, p. 12-16.

MARCHAND G., TSOBGOU AHOUPE R. 2007 - Comprendre la diffusion des roches au Mésolithique en Bretagne : analyse structurale des matériaux et variabilité technique, Archéosciences, 31, p. 113-126.

MARCHAND G., LE GOFFIC M., MARCOUX N. 2011 b - Occupations mésolithiques fugaces dans l'abri-sous-roche de Pont-Glas : une analyse de la segmentation des chaînes opératoires dans l'espace pour évoquer la mobilité des groupes préhistoriques en Bretagne, In : Bon Fr., Costamagno S., Valdeyron N. (dir.), Haltes de chasse en Préhistoire. Quelles réalités archéologiques?, actes du colloque international du 13 au 15 mai 2009, université Toulouse II - Le Mirail, p@lethnologie, 3, p. 313-333.

MARCHAND G., NAUDINOT N., PHILIBERT S., SICARD S. 2011 a- Chasse aux haltes sur un site azilien de l'Ouest de la France, In : Bon Fr., Costamagno S., Valdeyron N. (dir.), Haltes de chasse en Préhistoire. Quelles réalités archéologiques?, Actes du colloque international du 13 au 15 mai 2009, université Toulouse II - Le Mirail, P@lethnologie, 3, p. 271-294.

MARCHAND G., SICARD S., FORRÉ P. et NAULEAU J.-F. 2008 - De la pelle mécanique aux remontages lithiques : espace habité et techniques au Tardiglaciaire sur l'habitat des Chaloignes (Mozé-sur-Louet, Maine-et-Loire), Revue archéologique de l'Ouest, 25, p. 7-52. 
MARCHAND G., ARTHUIS R., PHILIBERT S., SELLAMI F., SICARD S., avec la collaboration de FORRÉ P., LANOË S., NAULEAU J.-F., QUESNEL L., QUERRÉ G. 2009 - Un habitat azilien en Anjou : les Chaloignes à Mozé-sur-Louet (Maine-et-Loire), Gallia-Préhistoire, 51, p. 1-113.

MARCHAND G., BLANCHET S., CHEVALIER G., GALLAIS J.-Y., LE GOFFIC M., NAUDINOT N., YVEN E. 2004 - La fin du Tardiglaciaire sur le Massif armoricain : territoires et cultures matérielles, Paleo, 16 , p. $137-170$.

MARGUERIE D. 2000 - Végétation néolithique sous impact anthropique en Morbihan et dans le reste de la Bretagne. In : Cassen S. (Dir.), Eléments d'architecture (Exploration d'un tertre funéraire à Lannec er Gadouer, Erdeven, Morbihan. Constructions et reconstructions dans le Néolithique morbihannais. Propositions pour une lecture symbolique. Chauvigny : APC, Editions chauvinoises, 2000, 815 p.

MICHEL S., NAUDINOT N. 2009 - De retour à Guennoc, Revue Archéologique de l'Ouest, 26, p. 23-36.

MONNIER J.-L. 1980 - Le Paléolithique de la Bretagne dans son cadre géologique, Travaux du Laboratoire d'Anthropologie, Rennes.

MOULLEC J-M. 1984 - Rapport de sondage archéologique, abri sous roche de Kerbizien (Huelgoat, 29). Rapport d'opération, SRA Bretagne, Rennes, 6 p., planches.

MOULLEC J-M. 1985 - Rapport de sondage archéologique. Abri sous roche de Kerbizien. Site ${ }^{\circ}$ 29.02.16.081.002. SRA Bretagne, Rennes, 8p., planches.

NAUDINOT N. 2010 - Dynamiques techno-économiques et de peuplement au Tardiglaciaire dans l'Ouest de la France, Thèse de doctorat de l'Université de Rennes 1, 731 p.

NAUDINOT N. 2013 - La fin du Tardiglaciaire dans le Nord-Ouest de la France, Bulletin de la Société Préhistorique Française, t. 110, 2, p. 233-255.

YESNER D. 1980 - Maritime Hunter-Gatherers: Ecology and Prehistory, Current Anthropology, 21, 6, p. $727-750$.

\section{ABSTRACTS}

The Kerbizien rock shelter on the commune of Huelgoat (Finistere) opens in an enormous granitic block installed in top of slope. It measures $9.50 \mathrm{~m}$ with the opening for approximately $5.50 \mathrm{~m}$ of depth, with a height under ceiling of $2.80 \mathrm{~m}$ from the rock base. The liveable space is approximately $11 \mathrm{~m}^{2}$. Its sedimentary filling was almost completely destroyed at the beginning of the years 1980 , but a survey in the cavity allowed J.-M. Moullec to describe with precision various cultural components (Final Palaeolithic, Mesolithic and the middle Ages). The excavation carried out in July 2011 made it possible to identify Tardiglacial levels (Azilian) at the bottom of the cave in a two meters broad band along the wall. This level consisted of a mixture of silts and granitic sands resulting from the erosion of the monolithic block. Some charcoals were collected in the US 4 and 5, but they are quite rare and thus questionable as a radiocarbon date confirmed it. The archaeological materials collected during the excavation are lithic tools (mainly flint, but also Eocene sandstone, microquartzite, cataclasite and chalcedony), small pieces of schist and three large summarily worked granite blocks.

Among the 1313 lithic pieces, 20\% come from the homogeneous Tardiglacial stratigraphical units. Curved backed points, large blades very used and falls of graver compose an industry easily comparable with Azilian in an old phase. It is very rare in the North-West of France. Its functional signature is original and would be completely compatible with the assumption of a logistical station (i.e. field camp) of very mobile human groups. Their knowledge of the local 
geological resources is a significant component to be kept in memory, which shows that the courses were regular in this area.

L'abri-sous-roche de Kerbizien sur la commune de Huelgoat (Finistère) s'ouvre dans un énorme bloc granitique installé en sommet de coteau. Il mesure 9,50 $\mathrm{m}$ à l'ouverture pour environ 5,50 $\mathrm{m}$ de profondeur, avec une hauteur sous plafond de 2,80 $\mathrm{m}$ depuis le socle rocheux et une surface habitable d'environ $16 \mathrm{~m}^{2}$. Son remplissage sédimentaire a été presque intégralement détruit au début des années 1980, mais un tamisage des déblais et un sondage dans la cavité avaient permis à J.-M. Moullec de décrire avec précision les différentes composantes chrono-culturelles présentes, Paléolithique final, Mésolithique et Moyen-Âge. La fouille réalisée en juillet 2011 a permis d'identifier des niveaux en place du Tardiglaciaire (Azilien) au fond de la caverne. Ils formaient une bande de deux mètres de large le long de la paroi et étaient constitués d'un mélange de limons et de sables granitiques issus de l'érosion des parois. La totalité du site a été fouillée, à l'exception d'un bourrelet limoneux au sud-ouest du bloc dont la partie supérieure comprend des occupations aux vestiges indémêlables. Quelques charbons ont été recueillis dans les US 4 et 5, mais ils sont rares et donc sujets à caution; une datation par le radiocarbone l'a d'ailleurs confirmé. Le mobilier archéologique recueilli lors de la fouille comprend des roches taillées à destination de l'outillage (principalement silex, mais aussi grès éocène, microquartzite, cataclasite et calcédoine), de petites plaquettes de schiste et trois gros blocs de granite taillés sommairement. Parmi les 1313 objets archéologiques issus de la fouille et du tamisage, $20 \%$ proviennent des unités stratigraphiques tardiglaciaires en place. Pointes à dos courbes, grandes lames très utilisés et chutes de burin composent un assemblage aisément comparable à l'Azilien dans une phase ancienne, très rare dans le nord-ouest de la France. Sa signature fonctionnelle est originale et serait tout à fait compatible avec l'hypothèse d'une station logistique (i.e. halte de chasse) de groupes très mobiles. Leur connaissance des ressources géologiques locales est un élément important à garder en mémoire, qui démontre que les parcours étaient réguliers dans cette partie occidentale de la région, dénuée de silex en position primaire.

\section{INDEX}

Mots-clés: abri-sous-roche, Azilien, Bretagne, France, Mésolithique, Tardiglaciaire, technologie lithique

Keywords: rock shelter, Azilian, Brittany, France, Mesolithic, Tardiglacial, lithic technology

\section{AUTHORS}

\section{GRÉGOR MARCHAND}

UMR 6566 du CNRS - CREAAH, Laboratoire Archéosciences, Bâtiment 24-25, Université de Rennes 1, CS74205 - FR-35042 Rennes Cedex - gregor.marchand@univ-rennes1.fr

\section{JEAN-LAURENT MONNIER}

UMR 6566 du CNRS - CREAAH, Laboratoire Archéosciences, Bâtiment 24-25, Université de Rennes 1, CS74205 - FR-35042 Rennes Cedex

\section{FRANÇOIS PUSTOC'H}

UMR 6566 du CNRS - CREAAH, Laboratoire Archéosciences, Bâtiment 24-25, Université de Rennes 1, CS74205 - FR-35042 Rennes Cedex 


\section{LAURENT QUESNEL}

UMR 6566 du CNRS - CREAAH, Laboratoire Archéosciences, Bâtiment 24-25, Université de Rennes 1, CS74205 - FR-35042 Rennes Cedex 